\title{
ARCHITECTURE OF RIFTED CONTINENTAL MARGINS AND BREAKUP EVOLUTION: INSIGHTS FROM THE SOUTH ATLANTIC, NORTH ATLANTIC AND RED SEA - GULF OF ADEN CONJUGATE MARGINS
}

Mohriak, Webster Ueipass ${ }^{1}$

Leroy, Sylvie ${ }^{2}$

1. Universidade do Estado do Rio de Janeiro - UERJ/DGRG, Rio de Janeiro, Brazil

2. ISTEP, Institut des Sciences de la Terre Paris, UPMC Univ Paris 06 CNRS 75252 Paris Cedex 05 , France

email:webmohr@gmail.com ; sylvie.leroy@upmc.fr

\begin{abstract}
The tectono-sedimentary development of the South Atlantic is compared with the Central Atlantic margins, which are associated with major episodes of magmatism during the Mesozoic continental breakup. Subsequently, the Cenozoic breakup in the North Atlantic led to the formation of the volcanic Norwegian-Greenland conjugate margins. However, the DSDP boreholes in the magma-poor IberianNewfoundland margins have confirmed the occurrence of exhumed mantle at the ocean-continent transition. This possibility has been suggested for the South Atlantic margins, but still lacks confirmation by drilling.

The Red Sea and the Gulf of Aden may be considered as natural laboratories to study breakup processes and formation of divergent continental margins. Using key geological and geophysical data, we compare some of the structures observed in incipient stages of basin formation between the African and the Arabian plates with the structures observed in older sedimentary basins associated with the Gondwana breakup. We also analyze deep seismic reflection profiles and potential field data at the continent-ocean boundary of these conjugate margins, using palinspastic reconstructions to define the corresponding seismic pairs. We conclude the Red Sea and the Gulf of Aden display remarkable differences from the Iberian-Newfoundland margins and notable similarities with the South Atlantic margins.
\end{abstract}

\section{Keywords}

Conjugate margins, extensional tectonics, continental breakup models, Atlantic Ocean, Red Sea and Gulf of Aden. 


\section{Introduction}

The origin and evolution of continental divergent margins is a topic that has been debated for several decades in the context of individual sedimentary basins, based on observations and conceptual or theoretical models. Several recent works have focused on geodynamic mechanisms associated with continental breakup and formation of rifts, evaporite basins and carbonate to siliciclastic depositional sequences during the divergence of the plates. These models are based on field observations, seismic interpretation, physical and numerical experiments, and provide a holistic approach which considers the conjugate margins as part of a geodynamic process that started with lithospheric stretching and progressed to continental breakup and plate divergence by active spreading centers. One aspect that has recently brought the attention of geocientists and petroleum explorationists is the understanding of rift basins near the continent-ocean boundary in divergent margins, with alternative hypotheses involving mantle exhumation or increased volcanism that preceded the crucial moment of continental breakup.

This work provides an overview of the formation of sedimentary basins in the Central and South Atlantic margins, and discusses the characteristics of the margins considering alternative mechanisms of basin formation and their transition from continental to oceanic crust. We include a discussion on structural and stratigraphic similarities between the Atlantic margins and the Red Sea, and present high-quality regional seismic pairs from the South Atlantic and the Gulf of Aden, extending from the platform towards the oceanic crust formed around $112 \mathrm{Ma}$ and $18 \mathrm{Ma}$ ago, respectively. In the case of the Gulf of Aden, the transect crosses the present-day spreading center (the Sheba Ridge) providing a unique opportunity to assess the characteristics of the South Atlantic mid-ocean ridges associated with the early margin divergence. This comparison is emphasized with the imaging of the present-day spreading center in the Red Sea, which is compared with possible early spreading centers in the South Atlantic which were aborted and left stranded in one of the margins.

We also discuss the role of oceanic propagators (Hey et al. 1980) in the early stages of continental breakup and the sequential development of tectonic phases involving rift, salt tectonics and formation of oceanic crust. These processes are diachronous along the continental margins, and are controlled by plate tectonics whose kinematics, geochronology and geodynamics affected the sedimentary basins that are imaged by the seismic data in different stages of their development. We start with a brief discussion of the Gondwana breakup and subsequently compare some of the elements of the conjugate margins that have been formed in the Atlantic Ocean using the Red Sea and Gulf of Aden as modern analogs providing useful templates to interpret structures concealed by thousands of meters of sediments in the mature basins. Then we focus on the conceptual models that have been proposed for the formation of the conjugate margins, analyzing the characteristics of volcanic and magma-poor margins, interpreted as an end-member where mantle exhumation may occur during the final stages of rifting. 


\section{Gondwana breakup and formation of Atlantic divergent margins}

Along the Central and North Atlantic margins, the breakup of Pangea started in the Late Triassic, forming a number of rift basins that are located onshore and offshore Morocco to Iberia, in the African/Eurasia plate, and onshore and offshore the United States and Canada, in the North American plate (Austin et al. 1989; Wilson et al. 1989; Roy \& Piqué 2001; Davison 2005; Withjack \& Schlische 2005; Mohriak et al. 2008; Schettino \& Turco 2009).

North of the Central Equatorial Atlantic, the continental margins can be subdivided into three segments. The meridional segment, characterized by the Central Atlantic Magmatic Province (CAMP), extends north of the Equatorial Atlantic transform margins between northern South America and NW Africa. It is interpreted as a magma-rich margin with seaward-dipping reflector wedges offshore the North American margin (de Boer et al. 1988; Austin et al. 1990; Sheridan et al. 1993; Oh et al. 1995; Talwani \& Abreu 2000; McHone et al. 2005). The second segment extends north of Nova Scotia, and the conjugate basins corresponding to Newfoundland and Iberia (Fig. 1). These are characterized as magma-poor margins with reduced volcanic activity during the Early Cretaceous continental breakup (Manatschal \& Bernoulli, 1998; Tucholke et al. 2007). The segment north of the Bay of Biscay margin is characterized by an Early Tertiary breakup and development of volcanic margins between Greenland and United Kingdom/Norway (White \& Mckenzie 1989). Although both the Central and the North Atlantic margins evolved from a Triassic-Jurassic rifting, their seafloor spreading was initiated during the Jurassic, in the Scotian Basin, and during the Early Cretaceous to Early Tertiary further north.

The western Gondwana breakup began by Late Jurassic in the southernmost extremity of the South Atlantic (Argentina/Namibia-South Africa) and advanced towards the Eastern Brazilian/Western African continental margins by Early Cretaceous (White \& McKenzie 1989; Rosendahl et al. 2005; Mohriak et al. 2008; Blaich et al. 2011). Several basins along the South Atlantic conjugate margins are characterized by similar tectono sedimentary evolution, such as the magma-rich Argentina - Namibia margins, the moderately magmatic Santos-CamposEspírito Santo-Angola margins, and the magma-poor Bahia-Sergipe-Gabon margins (Fig. 1). However, dramatic differences occur in diverse segments of the South Atlantic continental margins, from very wide rifted basins with a thick layer of Aptian salt to very narrow basins with no evaporite deposition (Davison 1997).

The divergent margins in the South Atlantic share some common characteristics with the North Atlantic margin sedimentary basins. For example, the Scotian Basin, offshore Canada, is also characterized by pre-rift, syn-rift, transitional and drift tectonic phases that show a remarkably similar development to some South Atlantic basins (e.g., Campos Basin, Fig. 2). This can be demonstrated in simplified cross-sections based on seismic images from the 1980's and 1990's (Fig. 2). However, the crustal architecture, rift structures, salt tectonics and magmatic episodes are quite specific to each of these basins, and particularly in the Campos 
Basin, all of these elements have radically changed in interpretation due to petroleum exploration advancing towards the deep water region. Moreover, although the tectonostratigraphic comparisons (Fig. 2) highlights several similarities, the petroleum systems in these basins have resulted in different creaming curves for the petroleum exploration results. While the Campos Basin is one of the most prolific basins of the South Atlantic, producing about two million boe/day, the Canadian and the conjugate NW African margins are characterized by much less prolific basins. This may be related either to much deeper basement in the Canadian margin, particularly in the gas-prone Scotian Basin, or to source rock productivity. In the Campos Basin the source rocks are associated with continental lacustrine sediments in the presalt sequence, whereas confirmed source rocks in the Canadian margin are related to post-salt Jurassic to Cretaceous sediments (Kidston, 2002; Brown et al. 2008). However, in the Scotian Basin there is new evidence for possible oil-prone source rocks from Late Triassic continental lacustrine (pre-salt/pre-breakup) to Early Jurassic shallow marine (post-salt/post-breakup) successions (OETR Association 2011; Luheshi et al. 2012).

The Iberian margin, conjugate to the oil- and gas-prone Newfoundland margin, is even less prolific, and petroleum exploration has not resulted in significant hydrocarbon discoveries so far. Its tectonic development is characterized by reduced magmatic events during the syn-rift phase (Late Triassic-Early Jurassic) and by an extended period of reduced sedimentation and tectonic activity until the continental breakup in the Early Cretaceous. It was strongly affected by compressional episodes in the Late Tertiary, which are not typical for the Canadian or the Brazilian margins. However, a common characteristic for the South Atlantic and North Atlantic margins is the development of an alluvial, fluvial and lacustrine syn-rift phase preceding the transitional phase with evaporite deposition. This took place during Late Triassic-Early Jurassic in the North Atlantic, and during the Early Cretaceous in the South Atlantic (Fig. 3). Most of the Late Aptian salt in the evaporite basins along the South Atlantic conjugate margins occur in deep water regions, whereas there is no evidence for large scale Late Triassic salt deposition basinwards of the Lusitania Basin syn-rift troughs offshore Iberia (Alves et al. 2006).

Following the transitional sequence with evaporite deposition, a marine transgression with shallow water carbonates is observed both in the South Atlantic and in the Central to North Atlantic continental margins. Along the Canadian - Iberian margins this carbonate platform may be associated with development of the early Central Atlantic and the Tethys oceans in Eurasia (Maldonado et al. 1999). Subsequently, a marine transgressive phase is characterized by deep water siliciclastic deposition in the Brazilian - West African margins by Late Cretaceous, whereas this phase in the Iberian margin was characterized by a second period of rifting that led to final breakup between Newfoundland and Iberia by the Early Cretaceous. Onshore, the Atlas rift basin was aborted and affected by compressional events by Aptian - Albian times (Fig. 3).

The Tertiary marine regressive phase in the South Atlantic was characterized by major continental uplift onshore and progradation from the platform towards the deep water regions on both the Brazilian and West African margins. This resulted in several stratigraphic intervals with sand-prone turbidite deposits, forming major hydrocarbon reservoirs (Davison 1999). Sparse drilling results from the Canadian margin have indicated a more reduced sand input in the margin, thus reservoirs for the post-Cretaceous sequence deposited during the plate divergence 
from Europe and NW Africa remain unknown. The Iberian margin was affected in the Tertiary by the convergence between Africa and Europe, while plate rotation in the Mediterranean Sea resulted in the development of Neogene oceanic crust in the Alboran region (Casado et al. 2001).

The North Atlantic continental margins (between Greenland and Norway) were formed in the Late Cretaceous/Early Tertiary as a result of extensional tectonics and propagation of sea-floor spreading centers from the south to the north. Massive volcanic episodes during the breakup are probably related to the Iceland plume. This resulted in a very large igneous province, which is marked by wedges of seaward-dipping reflectors that are imaged along the east coast of Greenland and west coast of the United Kingdom and Norway (Hinz et al. 1993).

In summary, the Mesozoic Pangea breakup resulted in formation of conjugate margins that are typically related to magmatic episodes preceding the inception of oceanic crust, with the notable exception of the segment corresponding to Newfoundland-iberia. An overview of the more recent breakup episodes and the development of incipient oceanic crust in young oceans may throw some light into the processes and structures that are associated with divergent continental margins.

\section{The Arabian - African breakup and the formation of the Red Sea and Gulf of Aden}

The Red Sea and the Gulf of Aden rift basins developed in Late Tertiary times as a response to plate movements between Africa and Arabia. They can be considered as one of the best natural laboratories on Earth for observation and analysis of the processes related to lithospheric extension, rift formation and the early generation of oceanic crust. The geometry of the Red Sea coastlines in African and Arabia and their conjugate escarpments on land were noted by many geoscientists, including Wegener (1912), who quoted the similarities between the two sides of the Red Sea as support of his theory on plate separation and continental drift.

The Red Sea is a fault-controlled depression that lies between North Africa and Arabia, and extends for about $2000 \mathrm{~km}$ from the Gulf of Suez and Gulf of Aqaba in the north to the Bab elMandeb Strait, which connects with the Gulf of Aden between Somalia and Yemen (Fig. 4). The central part of the Red Sea is marked by a deep depression with an unusual seafloor in which hot brine concentrates heavy metal oxides. These are dispersed in the mud layer that overlies basalts, reaching a thickness of about $10-20 \mathrm{~m}$ in the region adjacent to the axial ridge (Taviani, 1998).

It is estimated that the movement between Africa and Arabia began in the Early Tertiary (55$45 \mathrm{Ma}$ ), and was associated with and Early Tertiary subduction zone in the Persian Gulf (Hempton 1987). The Gulf of Suez opened about 30 m.y. ago, and the northern Red Sea about $20 \mathrm{Ma}$, forming patches of oceanic crust in the central segment around 5-3 m.y. ago (Bosence 1998; Bosworth et al. 2005). The spreading, with divergence rates of about 1.5 to $2.0 \mathrm{~cm} / \mathrm{year}$, is still proceeding. This is indicated by magnetic anomalies, seismic activity, the flow of hot brines in the axial trough, and by extensive volcanism in Holocene times. The latter has formed one of the largest LIPs (large igneous province) in the horn of Africa, near Afar, where a triple 
junction between the Red Sea, the Gulf of Aden and the East African Rift System developed above a mantle plume (Hayward \& Ebinger 1996; Wolfenden et al. 2004).

Although there is some disagreement about the exact location of the continent-ocean boundary in the Red Sea, most researchers are in general agreement that a small ocean basin with organized sea-floor spreading center has been formed in its central-southern portions, whereas the northern Red Sea and the Gulf of Suez might still be in the syn-rift phase, with no oceanic crust (Cochran 1981; Montenat et al. 1988). In the central and southern Red Sea, the mid-ocean ridge is characterized in the median valley with an axial trough that may reach water depths of more than $2000 \mathrm{~m}$, and by a basaltic oceanic crust with magnetic anomalies indicating the breakup age and formation of new crust in the last few million years (Ligi et al. 2011).

Magnetic and gravimetric anomalies associated with oceanic spreading are also observed in the Gulf of Aden (d'Acremont et al. 2006, Fig. 5), where the breakup between Somalia and Yemen occurred around $18 \mathrm{Ma}$, at least 5-10 Ma before the salt deposition in the Red Sea (Bosworth et al. 2005). Based on identification of oceanic crust magnetic anomalies, the continental breakup between Somalia and Arabia is estimated around 20 Ma between Oman and Socotra, and around 16 Ma towards the western Gulf of Aden, where the present-day Aden propagator is advancing towards Afar (Fournier et al. 2010). This suggests diachronous drifting between the Gulf of Aden and the Red Sea, similar to the differences in chronology observed for the rifting and continental breakup of the North Atlantic. In segment 1, between the North American and the NW African margins, the breakup developed during the Jurassic, whereas the breakup in segment 2 developed during the Early Cretaceous, and in segment 3, between the Greenland and Norwegian margins, it developed during the Early Tertiary. Diachronous drifting has also suggested for the South Atlantic, with Jurassic breakup between Argentina and South Africa, and Early Cretaceous breakup in the East Brazilian-West African margins (Rabinowitz \& LaBrecque 1979).

Some models assume widespread oceanic crust in the entire Red Sea basin, from the axial trough towards the coastline (McKenzie et al. 1970; Girdler \& Styles 1974; Le Pichon \& Francheteau 1988; Le Pichon \& Gaulier 1988). Other models assume gradual focusing of individual magmatic intrusions into organized sea-floor spreading in the axial trough, characterized by symmetric magnetic anomalies (LaBrecque \& Zitellini 1985). These models suggest that oceanic crust is restricted to the axial graben where new crust is formed by diffuse extension (Cochran 1982) or by punctiform initiation of sea-floor spreading (Bonatti 1985). Some authors interpret that the early phases of oceanic crust development are probably related to oceanic propagators (Manighetti et al. 1998; Mohriak 2001), whereas others assume a synchronous development of the rift basins along the margins (Leroy et al. 2012).

There is also some dispute whether the plate separation mechanism is related to pure shear forming symmetric basins (Lowell \& Genik 1972; Cochran 1983) or to simple lithospheric shear model resulting in asymmetric conjugate margins (Wernicke 1985, Lister et al. 1986; Voggenreiter et al. 1988). In addition, some recent studies have proposed the occurrence of exhumed mantle between the rift basin and the first oceanic crust, based on observations of outcropping rocks in the Alpine basins and the results of DSDP boreholes in Iberia and 
Newfoundland (Beslier et al. 1996; Withmarsch et al. 2001). This possibility has also been suggested for the Gulf of Aden eastern margin (Leroy et al. 2004; d'Acremont et al. 2005; Leroy et al. 2010b; Watremez et al. 2010; Lucazeau et al. 2010). However, the evidence for a wide belt of exhumed mantle below the Neogene sediments in the Red Sea, as proposed by some authors (Voggenreiter et al. 1988; Bohannon 1989; Voggenreiter \& Hotzl 1989) is scanty. The only indication of exhumed mantle rocks in the central Red Sea has been found on the small Zabargad island, which is formed by relatively fresh peridotites associated with basement rocks and small patches of Neogene sediments (Bonatti et al. 1986). According to some authors, this occurrence might be related to compressional transform faults and uplift of oceanic blocks (Bonatti et al. 1981; Bonatti et al. 1983).

On the other hand, several DSDP boreholes have sampled the axial trough in the central to southern Red Sea, indicating a thick layer of evaporites overlying the substratum. Dredging samples and side-scan images indicate that the spreading center is associated with volcanic features, basaltic rocks and gabbros (Monin et al. 1982; Cochran 1983; Cochran 2005; Cochran \& Karner 2007, Mitchell et al. 2010). Some of the recent presalt exploratory boreholes in the South Atlantic, drilled in regions close the continent-ocean edge, have also penetrated basalts and gabbros (Mohriak, 2011).

\section{Rifting evolution and sedimentary environments at breakup time}

The tectonic processes that control the development of successive depositional environments in the South and North Atlantic margins may be subdivided into a rift, transitional and an early drift phase. These stages are presently also observed in the Red Sea and Gulf of Aden (Fig. 6), with volcanism preceding the main rift phase in the southern Red Sea and/or coeval to the onset of rifting in the Gulf of Aden. Continental fluvial to lacustrine rocks were deposited in individual rift units, and salt deposition was widespread above the syn-rift fill, particularly in the Red Sea and Gulf of Suez (Bosworth et al. 2005).

There have been many discussions on the timing of formation of salt structures in the South Atlantic and in other salt basins worldwide. Some basins are characterized by a rather long period of stability in the salt layer before forming the first salt pillows which eventually evolve into salt diapirs (Trusheim, 1960). However, salt tectonics has already started in the Red Sea, and in some areas they are already in an advanced stage of evolution, including some allochthonous salt features. This indicates that halokinetic structures were developed within only a few million years after salt deposition. Carbonate sedimentation subsequent to the formation of an active spreading center also seems to occur very rapidly after salt deposition in the Red Sea, with carbonate to deepwater sedimentation observed in the early drift phase (Bosence 1998).

Although several studies have suggested that in the South Atlantic the evaporite layer near the continent-ocean boundary overlies exhumed mantle (Unterneher et al. 2010; Scotchman et al. 2010; Zalán et al. 2011), some recently drilled boreholes targeting the pre-salt reservoirs

near the continent-ocean boundary in the Santos Basin, offshore Brazil, sampled Early Cretaceous basalts (Mohriak, 2011). 
Seismic interpretation and physical and numerical modelling also indicate that the Atlantic continental margins are characterized by multi-phase rift evolution, and the focus of the final breakup is more often associated with reactivation of extensional faults and magmatic activity (Lentini et al. 2010; Huismans \& Beaumont, 2011). However, in deep water regions of the South Atlantic these features are most often hidden by a thick layer of salt and post-breakup sediments, and even with deep seismic images the transition from continental to oceanic crust is still elusive in many basins.

Recently there has been a plethora of works proposing the universal applicability of the models/concepts from the Iberian and Newfoundland margins, which are mainly based on a single seismic transect in these conjugate margins and some boreholes drilled in ridge-like features (e.g. Direen et al. 2011). The Newfoundland-Iberian margin has been thoroughly studied by different research groups and drilled by DSDP boreholes in key tectonic settings, resulting in a rather constrained crustal architecture model for the area (Discovery Working Group 1998). However, variations of the original conceptual model (as proposed by Boillot et al. 1980) have been recently used as a paradigm for the breakup of continents and formation of continental margins (Bowling \& Harry 2001; Karner 2008; Unternehr et al. 2010; Zalán et al. 2011).

In this work we address a different hypothesis for the breakup of the Atlantic margins and analyze geological and geophysical data that indicate that the Red Sea and Gulf of Aden margins might correspond to a more appropriate analog to other divergent margin systems worldwide than the Iberian-Newfoundland model. We discuss the similarities and differences of stratigraphy and tectonic evolution between the South Atlantic and the Red Sea - Gulf of Aden rift system, compare the initial development of salt structures, and the birth of an early oceanic crust. This young oceanic rift system can be interpreted as a modern analog for the Atlantic breakup processes as the embryonic spreading centers formed only locally in late Neogene times, and there is minor sedimentation in the axial trough, allowing unprecedented seismic imaging of the embryonic oceanic ridges that are separating the African and Arabian plates.

The deep-water region of the South Atlantic central segment is represented by a prolific petroleum belt along the Brazilian and West African margins, sourced by continental lacustrine rocks deposited on a volcanic basement (Chang et al. 1992). It is also characterized by a thick salt layer that was deposited at the last stages of continental rifting, accumulating in a deep basin almost concomitant with inception of volcanic crust by oceanic propagators (Mohriak 2001).

The interpretation of regional deep seismic profiles in the Aptian salt basins suggest that evaporites were mobilized from the platform towards the incipient axial troughs and advanced as allochthonous salt tongues towards the continent-ocean boundary (Mohriak et al. 2008; Blaich et al. 2011). This mechanism resulted in massive salt walls separated by an incipient spreading center, in a process similar to what is observed in the Red Sea margins, where the initial continuous salt layer is ruptured by the spreading center, but is still questionable for the South Atlantic (e.g., Girdler \& Whitmarsh 1973; Jackson et al. 2000; Mohriak 2005). On the contrary, there is no salt in the continent-ocean transition in the Iberian margin. These 
differences, together with some observations of the tectonic evolution of the Newfoundland Iberia margins as compared to the South Atlantic divergent margins, are summarized in Table I.

It needs to be said that the deep water province of the Iberian and Newfoundland margins is radically different from the geological environments observed in the South Atlantic. The exhumed Iherzolite ridges in the Iberian margin are characterized by a lack of any significant magnetic anomaly (Boillot et al. 1980; Whitmarsh et al. 1996). They occur adjacent to highly tilted rift blocks in a hyper-extended continental crust with minor indications of pre-, syn- and post-rift volcanism (Whitmarsh et al. 2001). These ridges occur in water depths exceeding 4000 $\mathrm{m}$ and are overlain by pelagic sediments deposited in abyssal environments (Beslier et al. 1993). The outermost highs in the South Atlantic continental margins are often characterized by magnetic anomalies indicative of volcanic intrusive and extrusive rocks. The sediments overlying these highs were originally deposited in shallow water, as attested by the reefal carbonates or microbiolites in the Tupi oil field (Formigli 2007; Carminatti et al. 2008). 


\section{The rift basins in the Gulf of Suez, Red Sea and the Gulf of Aden margins: some comparisons with the South Atlantic}

In the Gulf of Suez area, Precambrian basement rocks are overlain by about $500 \mathrm{~m}$ of pre-rift sediments dated as Late Cretaceous to Paleogene (Fig. 6). Towards the central Red Sea, the Precambrian crystalline basement rocks are directly overlain by syn-rift and post-rift (Neogene) sediments. The disappearance of the pre-rift section towards the south is indicative of uplift and erosion of the Paleozoic to Paleogene pre-rift sediments (Purser \& Hotzl 1988). Pre-rift sediments include the continental Nubian sandstones, which were deposited in fluvial environments. These rocks grade upwards into Quseir shales deposited in littoral environments that evolved into open marine, resulting in deposition of limestones in Paleocene times. This Paleogene transgression terminates with the deposition of the Eocene cherty limestones, deposited in open marine environments (Thebes Fm., Fig. 6). Uplift is indicated by continental syn-rift sedimentation in the Oligocene, which is associated with drastic facies changes and extensional tectonics, particularly with normal and strike-slip faults controlling syn-rift depocenters.

The northern Red and Gulf of Suez / Gulf of Aqaba are characterized by extensional faults controlling rift basins from the onshore region towards the central axis of the Red Sea. The Late Tertiary evaporite deposits occur as gypsum beds onshore and as salt diapirs offshore. There is no clear evidence for an active spreading center in the northern Red Sea, and the Gulf of Suez might have been aborted as the transform fault between the Sinai Peninsula and Arabia formed the Gulf of Aqaba / Dead Sea rift systems, in a process similar to the abandonment of the onshore Recôncavo-Tucano-Jatobá rits in Brazil (Szatmari \& Milani 1999; Rosendahl et al. 2005). In this case, transform faults developed as the oceanic crust was formed between the Bahia - Sergipe and northern Gabon continental margins

Further south, in the Central Red Sea $\left(24^{\circ} \mathrm{N}\right.$ to $\left.19^{\circ} \mathrm{N}\right)$ the seismic, gravity and magnetic surveys indicate that oceanic crust occurs on both flanks of the axial trough, where a presentday spreading center is indicated by seismic data. The volcanic basement is also interpreted towards the platform, extending about 20 to $40 \mathrm{~km}$ beyond the oldest recognizable magnetic anomalies (Rihm \& Henke 1998). Several authors (e.g., Bosworth et al. 2005) suggest that the rifting process in the Gulf of Aden resulted in formation of oceanic crust earlier than in the Central Red Sea. Fournier et al. (2010) indicate that the age of the oceanic crust gets younger from east to west, with the age of emplacement of the spreading center (Sheba Ridge) varying from more than $20 \mathrm{Ma}$ east of Socotra Island (north of Somalia) to less than $10 \mathrm{Ma}$ at the longitude of the city of Aden. From Aden city to Afar there is an E-W propagator characterized by magnetic anomalies younger than 2.6 Ma (Leroy et al. 2012).

The Afar region was affected by a mantle plume in the Neogene and formed a large igneous province (LIP) at the triple junction between the Red Sea rift and the East African Rift System around 20-10 MA (Fig. 7). Between 10 MA and 5 MA the Red Sea and the Gulf of Suez were desiccated and a major evaporite basin formed in the incipient divergent margins between the Nubian shield and the Arabian plate (Fig. 7). On the other hand, there was communication 
between the Afar region and the Gulf of Aden through the open Indian Ocean in the east, such that the Late Miocene sea in the central Gulf of Aden had normal salinity and evaporites were not deposited. However, aridity was prevalent in the region from 10 to $5 \mathrm{Ma}$, and sabkha deposits are registered in some onshore rifts at the conjugate margins, e.g., Jiza-Qamar and Masilah basins in Oman, Berbera and Nogal grabens in Somalia (Leroy et al. 2012).

There is a continuous salt province between the two sides of the Gulf of Suez and also in the northernmost and southernmost Red Sea. In the central to southern Red Sea, huge salt diapirs and salt walls are separated by the incipient spreading center. Large salt lenses, covered by a thin veneer of sediments, are apparently advancing towards the axial trough by gravity gliding (Mitchell et al. 2010). Salt is advancing from the shallow water platforms towards this depression in the central to southern Red Sea; in the Gulf of Aden no salt is observed between the rifted continental margins and the spreading center, indicating that the connection with the Arabian Sea and Indian Ocean prevented evaporation of the seawater and a total desiccation of the basin. Only a few boreholes drilled the pre-salt sequence in the Red Sea, most of them stopped when the Miocene age salt was penetrated. (Mitchell et al. 2010).

It is remarkable that halokinesis has been triggered by clastic progradation and extensional tectonics after only a few million years since salt deposition in the Red Sea, forming autochthonous and allochthonous structures (Davison et al. 1996; Davison et al. 1996). This contrasts with other basins where the salt layer was stable for a long period of time before it was affected by extensional tectonics or sediment progradation (Jackson \& Vendeville, 1994). A comparison between the Gulf of Suez salt structures and the South Atlantic salt structures in the proximal part of the Santos Basin (Fig. 8) provides clues on timing of halokinesis and possible depositional environments that followed salt deposition in both cases. Comparing the outermost salt walls in the southern Red Sea (offshore Ethiopia, Savoyat et al. 1989) with salt structures in the Santos Basin offshore Brazil, where giant oil discoveries have recently been proved in the pre-salt reservoirs (Formigli 2007), indicates a remarkable similarity (Fig. 9). In both cases, the rift sediments are overlain by more than $2000 \mathrm{~m}$ of stratified evaporites, and these are covered by a thin layer of sediments deposited in a distal part of the margin during the drift phase. However, the salt province in the Santos Basin extends farther basinwards than the Tupi oil field structure (Carminatti et al. 2008; Henry et al. 2009), whereas the Red Sea analog (offshore Ethiopia) is characterized by a rapid transition to oceanic crust.

Pre-rift volcanism in the southern Red Sea and western Gulf of Aden was dominated by the eruption of a large igneous province in Yemen and a smaller volume alkaline volcanism in Saudi Arabia (Fig. 5). Cenozoic magmatism in Yemen and Saudi Arabia is inextricably linked to upwelling mantle plumes beneath Afar and to sea-floor spreading in the Gulf of Aden (with magnetic anomalies indicating ages $18 \mathrm{Ma}$; Leroy et al 2012) and the Red Sea (ages < $5 \mathrm{Ma}$ ). Surface uplift and extension of the Afro-Arabian plate and formation of the Gulf of Aden and the Red Sea were accompanied by widespread magmatism exceeding over $>1$ million $\mathrm{km}^{2}$ on the western Arabian plate, from Yemen in the south to Syria and Jordan in the north (Chazot et al. 1998; Bosworth et al. 2005).

The major periods of extension/erosion that affected the Red Sea margins (Sudan/ Ethiopia and Arabia-Yemen) occurred before 26 Ma and were essentially synchronous (Omar \& 
Steckler 1995). Erosion and breakup on the Yemeni margin of the Red Sea was associated with the emplacement of intrusive and plutonic rocks, which date from 35 to $16 \mathrm{Ma}$ (i.e., syn-rift volcanism, Davison et al. 1994; Davison et al. 1998). On the Yemen side of the Red Sea, the emplacement of syn-rift volcanism generally spans the interval 40 to $16 \mathrm{Ma}$, which locally corresponds to a sequence of lava flows or trap basalts onshore, particularly near the Gulf of Tadjura.

Offshore the city of Aden, located near the strait that separates the Red Sea from the Gulf of Aden, seismic images suggest seaward-dipping reflector wedges that are linked to the incipient spreading center (Tard et al. 1991; Bosworth et al. 2005). Radiometric data indicates that the eruption of several thousand metres of the Yemen LIP (from 35 to $26 \mathrm{Ma}$ ) predated break up and erosion on the Yemen margin by a few million years. This indicates that the pre-rift volcanism (older than $35 \mathrm{Ma}$ ) was close in time with the development of the syn-rift structures (dated from 34 to $18 \mathrm{Ma}$ ). The volcanism is partly coeval to the opening of the Gulf of Aden and was soon followed by inception of oceanic crust (around 17.6 Ma).

This replicates the magmatic episodes in the South Atlantic, as the Paraná Basin LIP (Serra Geral/Etendeka basalts, which yield radiometric ages around $133 \mathrm{Ma}$ ) erupted prior to the main rift episode in the continental margin (Mizusaki et al. 2002). Subsequent to the rift climax (130-120 Ma), which is characterized by active faults with fast sedimentation rates, the continental margin basins accumulated a thick sag basin (120-115 Ma) with siliciclatic and carbonate deposition, which was followed by salt deposition (115-112 Ma) and shallow-water carbonate environments (around 110-100 Ma). Basinwards of the salt basin, the oceanic crust was formed and overlain by deep-water carbonates and siliciclastic rocks. Consequenly, in the South Atlantic the breakup occurred about 20 m.y. after the first magmatic episode, and is locally characterized by wedges of seaward-dipping reflectors in the Pelotas, Santos, Campos and Espírito Santo basins. Near the continent-ocean transition, these volcanic rocks are immediately overlain by Late Aptian salt and Early Albian carbonates (Gladczenko et al. 1997; Mohriak 2003).

Syn-rift volcanism in the Red Sea region was characterized by intrusion of a major tholeiitic dike swarms in Saudi Arabia running sub-parallel to the Red Sea axis, and by intrusion of sub-volcanic plutonic and intrusive rocks in western Yemen (Fig. 5). Post-breakup volcanism with extrusive rocks occurred throughout the Afar region, probably indicating a long-lived mantle plume (Leroy et al 2010a). This resulted in one of the largest alkaline provinces on earth, which extends across the conjugate margins at the western extremity of the Gulf of Aden (Fig. 5).

The Gulf of Aden is a young ocean, with oldest oceanic crust dated by anomaly $5 \mathrm{~d}$ (around 17.6 Ma) recognized between the Owen Fracture Zone and the Socotra-Hadbeen Fracture Zone (Fournier et al. 2010). West of the Shukra El Sheik Fracture Zone (near the city of Aden, at $45^{\circ} \mathrm{E}$ ) the magnetic anomalies indicate oceanic crust younger than $9 \mathrm{Ma}$ (Leroy et al. 2012). Oceanic crust in the Gulf of Aden thus extends from $57^{\circ} \mathrm{E}$, between east of Socotra Island and southern Oman, and is at present propagating westwards from the Shukra el Sheik fracture zone towards the Gulf of Tadjura in Djibouti (Cochran 1981; Fantozzi 1996). The Aden propagator is associated with active volcanism both offshore and onshore the Afar region 
(Manighetti et al. 1998; Ebinger et al. 2008), and is characterized by magnetic anomalies that are rather similar to the pattern observed on oceanic crust.

The present-day spreading center structure is characterized by an axial oceanic Sheba Ridge, which is segmented by several transform faults expressed by approximately northeastsouthwest fracture zones, i.e., Shukra EI Sheik, Alula-Fartak and Socotra. The Sheba Ridge is characterized by segments trending W-NW/E-SE, in an-echelon pattern that is left-lateral from $52^{\circ} \mathrm{E}$ to $44^{\circ} \mathrm{E}$ (Leroy et al. 2004; d'Acremont et al. 2010). Off-axis volcanism in the northern Gulf of Aden is also identified in the east of the Alula-Fartak fracture zone and on the oceancontinent transition (OCT) offshore south Oman (Lucazeau et al. 2009; Autin et al. 2010; d'Acremont et al. 2010; Leroy et al. 2010a; Watremez et al. 2011). The onset of the volcanism is supposed to mark the continental break-up and early drift phases. Low velocity anomalies in the upper mantle are imaged below the northern margin of the Gulf of Aden, indicating that partial melting occurs under the rift basins (Basuyau et al. 2010), which could be related to the Afar plume influence affecting even the eastern parts of the Gulf (Leroy et al. 2010a). However, several studies indicate the possibility of mantle exhumation in the magma-poor segments of the Gulf of Aden, particularly eastwards of the Alula-Fartak Fracture Zone (Leroy et al 2010b; Leroy et al. 2012).

On the two margins of the Gulf of Aden, pre-Paleozoic metasediments and Paleozoic granites outcrop extensively in Somalia (44-47 ${ }^{\circ} \mathrm{E}$ ), and in the Aden-Al Mukalla region in Yemen $\left(44-50^{\circ} \mathrm{E}\right)$. These rocks are overlain by a major unconformity blanketed by Jurassic to Quaternary sediments. Jurassic to Eocene pre-rift strata are grouped into various formations, clearly correlative on both sides of the Gulf of Aden (Fig. 6). In the eastern Dhofar region (southern Oman) and in Socotra Island (north of Somalia), the basement is unconformably overlain by Cretaceous (Cenomanian) units (Roger et al. 1989). In NE Somalia the Eocene is characterized by the Taleh Fm., which include some evaporites (e.g., gypsum).

Post-Eocene strata in the sedimentary basins along the eastern Gulf of Aden are laterally discontinuous and were deposited in downfaulted blocks, above an unconformity related to the breakup of the crust and inception of oceanic crust between the margins. Rift shoulder uplift and faulting are generally reported as being of lower Oligocene in age, whereas another phase of faulting is inferred to occur at the Oligo-Miocene boundary. Rift blocks are observed in seismic profiles offshore the northern Gulf of Aden (Leroy et al. 2004; d'Acremont et al. 2005; d'Acremont et al. 2006; Autin et al. 2010; Leroy et al. 2010b), indicating that extensional tectonics affected the rifted crust until the Late Miocene (Leroy et al. 2012).

The formation of oceanic crust in the Gulf of Aden and in the Red Sea has been studied by several earlier workers (e.g., Lowell \& Genik 1972; Cochran 1981, 1982, 1983; Cochran \& Martinez 1988; Martinez \& Cochran 1988; Cochran \& Karner, 2007; Ligi et al. 2011). Although at present there are no deep seismic reflection profiles extending across the conjugate margins and imaging the spreading center, several geophysical methods, including gravity, magnetic, sidescan sonar and academic seismic profiles, have provided important clues on the structures that are forming at the embryonic stage of sea-floor spreading. These might be compared with the South Atlantic analogs where deep seismic profiles are available. 
A refraction profile in the central Red Sea (Fig. 10) has been analyzed and compared with reflection seismic profiles in the region. Assuming the density and velocity of the different layers from sediments to mantle as proposed by Egloff et al. (1991), a synthetic reflection seismic profile was obtained (Mohriak et al. 2010). Interpretation of the refraction profile P1 and its comparison with seismic data from the Red Sea suggests a conceptual model for the conjugate margins in the Red Sea indicative of a very rapid thinning of the continental crust from onshore to offshore (Fig. 11).

The Conrad and the Moho discontinuities can be interpreted using the refraction data (Fig. 10), and the thickening of the salt basin beyond the shelfbreak appears to be similar to that observed in South Atlantic basins. The transition from continental crust to oceanic crust is marked by refraction velocities between 5 and $6 \mathrm{~km} / \mathrm{s}$, which might be associated with an igneous crust (Egloff et al 1991). The transition from this crust to the upper mantle rocks is very abrupt and marked by the Moho discontinuity at $5-8 \mathrm{~km}$ below sea level. Proto-oceanic crust in the Red Sea extends from the salt wall province to the oceanic crust; the latter being marked by magnetic anomalies M2 to M4 in the profile, indicating organized seafloor spreading for the last few million years. The earliest oceanic crust might be associated with a propagator in the axial trough, at the basinward limit of the salt layer (Fig. 11).

This conceptual model for the formation of the Sudan-Arabia conjugate margins (Fig. 11) indicates several similarities with the South Atlantic margin. The extremely thick salt layers in the axial trough are located in both conjugate margins, separated by an incipient spreading center. No clear indication of mantle exhumation due to extensional faults is interpreted in the central trough of the Red Sea (Cochran \& Karner, 2007). We suggest that the rift basins might be segmented in two compartments, one more proximal, with lacustrine sediments rich in organic matter, and a more distal rift (beyond the inferred economic rift limit) with a high influence of volcanic material. The region between the continental rifted margin (with potential pre-salt reservoirs) and the active spreading center is characterized in the South Atlantic and probably in the Red Sea by magmatic features and locally by seaward-dipping wedges that may underlie rift sediments and evaporites (Mohriak, 2001; Mohriak et aL 2010). Fault activity is also inferred to become younger towards the main trough, affecting the evaporite layer. This is interpreted to indicate two stages of oceanic crust inception. Initial spreading in the Red Sea (older than $3 \mathrm{Ma}$ ) might have occurred in regions adjacent to the present-day axial trough, where salt is present, and the recent phase of oceanic crust formation (3-2 Ma) is associated with the embryonic ridge located in the axial trough, where salt is absent (Fig. 11).

A comparison of the seismic profile through the central Red Sea (Thetis Deep, Mitchell et al. 2010) with a seismic profile in the South Atlantic (Fig. 12) indicates that oceanic propagators might separate salt basins on conjugate margins. If the propagator is abandoned during a ridge jump, some of the salt and some of the early volcanic rocks formed during incipient phases of spreading might be attached to one of the plates, but not be present at the other margin across the ridge jump. The spreading center in the Red Sea is at an embryonic stage of evolution and there are almost no sediments overlying it. In the Santos Basin example, the oceanic propagator was aborted by the Late Aptian/Early Albian (Mohriak 2001; Mohriak et 
al 2008) and a complete sedimentary succession from Albian to Recent is present above the structure (Mohriak et al 2010).

The Florianópolis Fracture Zone between the Santos and the Pelotas basins (Fig. 13-A) is marked by an E-W lineament which has been associated with volcanic basement (Mohriak 2001; Mohriak 2004) or exhumed mantle (Gomes et al. 2008; Zalán et al. 2011). The Abimael Ridge has been interpreted as an oceanic propagator advancing from the Pelotas Basin towards the southern Santos Basin (Mohriak 2001; Carminatti et al. 2008; Mohriak et al. 2008;) that failed to advance northwards and was aborted in the Late Aptian/Early Albian. Previous interpretations suggested asymmetric breakup between the conjugate margins, with the spreading center located closer to the African margin (Kumar \& Gamboa 1979). There are several possibly volcanic intrusions in the continental crust of this region, such as the Avedis Chain in the southern Santos Basin (Gomes et al. 2008). Dozens of boreholes that drilled through the salt and rift sequence recovered basalts dated as Early Cretaceous, similar to the Campos Basin basalts (Mizusaki et al. 2002; Mohriak 2003; Bueno 2004). In the SE Santos High, where the Tupi giant oil field was discovered in 2006, seismic data indicate the presence of basin floor volcanics and also some intrusive sills and dykes in the pre-salt sequence (Henry et al. 2009).

A regional seismic transect in the Southern Santos Basin illustrates the rift architecture and the salt tectonic styles on this segment of the margin (Fig. 13-B). It is characterized by basinward sliding of post-salt blocks in the platform, and by large salt diapirs and salt walls affected by compression in the deep water region (Demercian et al. 1993; Cobbold et al. 1995; Mohriak 2005). The oceanic propagator that advanced from the Pelotas Basin northwards and was aborted during the Early Albian apparently separated an original salt layer into two salt provinces, the larger one corresponding to the main salt province in the Santos Basin, and the smaller one, located to the SE of the main salt province, was ruptured by igneous intrusions and possibly by incipient seafloor spreading (Mohriak 2001; Gomes et al. 2008). Alternative interpretations suggest that the Abimael Ridge might correspond to exhumed mantle (Zalán et al. 2011) between the Pelotas and the southern Santos basins. However, the feature is characterized by a strong negative magnetic anomaly and by a positive gravity anomaly, and is associated with magmatic features in the Pelotas Basin to the south, suggesting an incipient volcanic spreading center. Major earthquakes are registered in the continental margin along SE Brazil (Fig. 13-A), indicating that there is some persistent tectonic activity. This is probably associated with flexural stresses up to the present day (Assumpção et al. 2011).

Towards the Pelotas Basin there is no evidence of mantle exhumation, although the Moho reflector climbs very rapidly near the ocean-continent transition and looses the strong reflectivity near the boundary with oceanic crust (Mohriak et al. 2010). A seismic profile in this segment (Fig. 14) indicates that the mantle rocks are strongly uplifted during the lithospheric stretching and crustal thinning, but volcanic rocks (including wedges of seaward-dipping reflectors) occur above the crust-mantle transition. The oceanic crust in northern Pelotas Basin is marked by magnetic anomalies indicative of organized spreading (Moulin et al. 2010; Blaich et al. 2011), similar to the present-day situation of the Gulf of Aden and some segments of the Red Sea. 
The Gulf of Aden is characterized by an active spreading center (Sheba Ridge) north of the Socotra Island. This ridge is offset by major NE/SW transform faults (Alula Fartak Fracture zone) towards the Aden Ridge (Fig. 15). The Bosaso Graben in Somalia and the Hami Graben in Yemen are conjugate margin rift structures separated by the Aden spreading center, which is presently propagating towards Afar (Gulf of Tadjura). In the region between Afar and Yemen (Fig. 15), Neogene basalts are affected by extensional tectonics, forming ridges and volcanoes that trend parallel to the Red Sea axial trough (Bastow \& Keir 2011).

The continental margins of the Gulf of Aden are characterized by several rift basins which are oblique to the main trend of the Gulf (Fig. 16). They occur from the southeastern margin of Oman towards the western segment of the gulf, near the triple junction between the Red Sea, the East African rift system and the Aden propagator. The conjugate margin in northern Somalia is also characterized by several rifts onshore and offshore, extending towards Socotra in the east (Samuel et al. 1997).

The Afar region (Fig. 17) is marked by large volcanoes and thick sequences of Cenozoic volcanic rocks. In several lakes evaporites are being deposited as the lakes are restricted by a Pleistocene volcanic barrier (Jackson et al. 2000). The Afar region is considered a present-day analog for the breakup of the continental margins between the northern Pelotas/southern Santos basins and the Walvis Basin in West Africa, which are characterized by substantial volumes of volcanics during their breakup (Mohriak, 2001).

A depth-migrated seismic profile in the northern branch of the eastern Gulf of Aden (ENC-34, offshore southern Oman, Fig. 16) suggests that continental crust was rifted in the Oligo-Miocene, resulting in deposition of firstly carbonate rocks in rift basins and then siliciclastic that extend towards the continental-oceanic transition (Fig. 18). The interpretation of the seismic data (Fig. 19) indicates that volcanic rocks were formed in the OCT zone, and the oceanic crust, which is here overlain by $3 \mathrm{~km}$ of sediments, is characterized by a basaltic layer overlying underplated rocks (gabbros and intrusive rocks) and the upper mantle (Autin et al. 2010; Leroy et al. 2010a; Watremez et al. 2011). The Moho discontinuity is indicated by seismic refraction data to occur at a depth of about 8-9 km below the seafloor, probably corresponding to the base of the layered reflectors that appear faintly imaged on the seismic profile, between the depths of 6 to $8 \mathrm{~km}$ (Fig. 16). This suggests a crustal thickness 4-6 km (Watremez et al. 2011), which although thin, is still within the observed ranges of oceanic crust thicknesses worldwide (White et al. 1992).

The Neogene rifts west of the Socotra Island are conjugate to the rifts in the southern Oman margin (Fig. 16). A reconstruction of the crustal architecture of the margins at breakup indicates a marked asymmetry between the margins, with a deep rift north of the Socotra Island. This margin is rather narrow when compared to the rift system in the conjugate southern Oman margin. This architecture is probably associated with a detachment fault dipping towards the north (Fournier et al. 2007) and controlling the rift basins in the conjugate margins (Fig. 20). A plate reconstruction for the pre-breakup setting (Fig. 21) indicates that the margins were characterized by inherited rifts onshore and offshore Yemen and Somalia, some of which were formed during pre-Tertiary extensional events (Bott et al. 1992; Leroy et al 2012). In the 
Neogene, the separation of the Somalia and Arabian plates by the Sheba Ridge resulted in extensional stresses and the rifted crust developed several basins that were controlled by accommodation zones which became transform faults or fracture zones during the continental margin drift (e.g d'Acremont et al 2010; Leroy et al 2010b).

\section{Continental breakup and magmatism in the North Atlantic and South Atlantic conjugate margins}

Rifting in the northernmost part of the Central Atlantic (Nova Scotia-Morocco) and the North Atlantic started in the Late Triassic/Early Jurassic, and resulted in the deposition of evaporites in a series of interconnected grabens between the Canadian and Iberian-Moroccan conjugate margins. These rift basins are overlain by a regional breakup unconformity (?Hettangian-Pliensbachian) that is widespread on the Central Atlantic conjugate margins (Welsink et al. 1990). The evaporites are almost coeval with emplacement of tholeiitic volcanic rocks (i.e., CAMP) in both onshore and offshore basins (Roy \& Piqué 2001; McHone et al. 2005; Brown et al. 2008; Luheshi et al. 2012). The southwestern Scotian Basin and the entire U.S. East Coast margin are magma-rich, being characterized by massive wedges of seaward-dipping reflectors (Keen \& Potter, 1995; Talwani \& Abreu 2000).

Moving northeastward along strike in Nova Scotia the volcanic features are less evident in the seismic profiles, especially east of $62^{\circ} \mathrm{N}$ up to the Orpheus Graben and the terrainbounding Cobequid-Chedabucto Fault Zone (Keen \& Potter 1995). Offshore Newfoundland the margin becomes magma-poor (Manatschal \& Bernoulli 1998; Péron-Pinvidic \& Manatschal, 2008;), although several authors have interpreted oceanic basalts in the transitional crust basinward of the Flemish Cap (e.g., Enachescu 1988). In the Newfoundland-Iberian margin conjugate rift pairs, a strong reflector on the seismic profiles along the Iberian margin is interpreted as an intracrustal detachment fault that soles onto serpentinized upper mantle near the continent-ocean boundary (Reston et al. 1996). This detachment may extend westwards towards the rift basins of Newfoundland (e.g., the Jeanne d'Arc Basin), assuming a simple shear mechanism for basin formation (Péron-Pinvidic et. al. 2007).

The oldest rift basins in the southern South Atlantic are related to the extensional stresses in the Mesozoic, as indicated by Triassic/Jurassic rifts in South Africa and Argentina (Tankard et al. 1995). This resulted from plate divergence subsequent to compressional tectonics associated with subduction and magmatism in early to mid-Jurassic times, which affected mainly the southernmost segment of South American and South Africa (Macdonald et al. 2003). Magnetic anomalies and paleontological dating of the syn-rift deposits also indicate younging of the rifting processes from south to north, and the climax of the rifting episode was coeval or immediately followed the emplacement of a mantle plume in the region between southern Brazil and Namibia (Macdonald et al. 2003).

Regional, deep penetrating seismic images through the SE Brazilian and conjugate West African margin indicate that several segments of these margins are characterized by the presence of seaward-dipping reflectors in the transition from continental to oceanic crust (Gladczenko et al. 1997; Franke et al. 2007; Blaich et al. 2011). 
The outermost highs in these basins have not been drilled and alternative interpretations of their origin have been proposed, including volcanic highs, Precambrian horsts, uplifted rifted blocks, and exhumed serpentinized mantle (Lentini et al. 2010; Scotchman et al. 2010; Unternehr et al. 2010; Zalán et al. 2011).

Geological data obtained from the petroleum exploration drilling offshore Brazil indicates that the breakup process along the eastern Brazilian margin was heralded by magmatism onshore and offshore in the Pelotas, Santos, Campos and Espírito Santo basins. The peak of magmatic activity is associated with the Serra Geral - Etendeka volcanism that pre-dates synrift sedimentation (Mizusaki et al. 2002). However, wedges of seaward-dipping reflectors post dating the Serra Geral - Etendeka volcanics are interpreted in the conjugate margins, not only in the Pelotas - Namibe basins, but also in the Santos-Campos- Espírito Santo province and in the African conjugate margin (Chang et al. 1992; Gladczenko et al. 1997; Jahnert et al. 1998; Franke et al. 2007; Blaich et al. 2011). These reflectors are interpreted to mark the continentocean transition towards an oceanic crust that was developed probably by Aptian time (about $112 \mathrm{Ma}$ ). Dating the magnetic anomalies associated with these volcanic wedges provides important insights, suggesting that rifting started in the southernmost basins (Argentina) and advanced northwards by oceanic propagators (Hinz et al. 1999; Mohriak 2001; Franke et al. 2010).

Inferences of Albian rifting processes (based on questionable seismic interpretation of fault-controlled syn-rift troughs, isopach mapping of the Albian carbonate sequences, and interpretation of basement-involved salt tectonics during rifting) are highly arguable as indicative of lithospheric rifting processes. The geometry and area distribution of the carbonate platform depocenters are mainly controlled by salt tectonics. The analysis of palinspastic reconstructions of the South Atlantic opening and breakup are also indicative of oceanic crust inception before the Early Albian in the southeastern Brazilian margin (Moulin et al. 2010). However, extensional reactivation episodes affecting Aptian and Albian sequences are locally observed in several segments of the conjugate margins, and these are observed even in the volcanic substratum associated with the oceanic crust.

The Rio Grande Rise, a major feature in the South Atlantic (Fig. 1), has been tentatively interpreted by some researchers as a fragment of continental crust or micro-continent affected by rifting. However, geological and geophysical data suggest it probably corresponds to an oceanic ridge (Gamboa \& Rabinowitz, 1984). It is characterized by a NW-SE trending lineament (Cruzeiro do Sul Lineament, Souza et al. 1993) and is also marked by igneous intrusions from oceanic crust towards continental crust, particularly near the Cabo Frio High (Bassetto et al. 2000; Mohriak 2003, Mohriak et al. 2010). The corresponding feature in the conjugate margin is the Walvis Ridge, which also seems to be associated with a major volcanism episode during the early phases of continental separation. These structures are thus related to a phase of abnormal volcanism formed at the initial stages of the plate divergence, straddling the spreading center.

In the western Gulf of Aden margins the Afar region is characterized by major volcanism both onshore and offshore (Figures 7 and 17). In the eastern Gulf of Aden magmatism has been 
interpreted in seismic profiles extending from the platform towards the Sheba Ridge, and some volcanoes are identified by seismic and potential field data. The region between the AlulaFartak and the Socotra-Hadbeen fracture zones (Fig. 16) is marked by a large volcanic province straddling the Sheba Ridge, indicating a period of enhanced magmatic activity from Recent to Pliocene (Leroy et al. 2010a; d'Acremont et al 2010). Volcanoes are also identified near the continent-ocean boundary in several seismic profiles (example, Fig. 18; Autin et al 2010; Lucazeau et al 2009).

A summary of the tectonic and stratigraphic evolution of the South Atlantic, as compared to the Red Sea / Gulf of Aden incipient development, suggests several similarities the sequence of events (Table II), and analogous exploratory plays in these margins.

\section{Conjugate margins pair profiles}

A transect using deep penetrating seismic images along the conjugate margins between eastern Brazil and western Africa (Espírito Santo-Kwanza basins, Fig. 22) indicates that the salt tectonic domains are controlled by the crustal architecture underlying the sedimentary basins, and the structural styles are highly influenced by subsidence patterns of each domain. On both margins, the conjugate margin seismic transect indicates extensional and compressional salt tectonic domains and igneous addition in the crust near the COB boundary (Mohriak 2003; Mohriak et al. 2008; Blaich et al. 2011).

The interpretation of magmatic accretion is based on geological and geophysical assumptions and comparisons of the oceanic crust seismic signature, particularly beyond the allochthonous salt tongues in the Espírito Santo Basin (Mohriak 2004; Mohriak et al. 2008). The post-breakup sedimentary layers overlie oceanic pillow basalts, which overlie lower crust igneous rocks, which in turn show a marked discontinuity with the upper mantle by a strong seismic reflector, thus corresponding to features highly suggestive of the crustal partioning that is commonly observed on ophiolites. Using the analogy provided by many outcropping ophiolite structures worldwide (which are associated with later compressional events that stacked oceanic material on continental crust), the seismic profile in the Espírito Santo Basin can be interpreted as a segment of oceanic crust covered by post-breakup sediments. These sediments were deposited on an upper basaltic layer overlying vertical sheeted dikes, intrusive igneous rocks, and possibly magma chamber and underplated rocks at the transition to the upper mantle peridotites (Karson et al. 1984).

A very think syn-rift sequence is interpreted in the Espírito Santo Basin, including a presalt sag basin that is also observed in the Angolan margin. Basinwards of the sag basin the massive salt layers make the visualization of the deeper structures more obscure, particularly in the ocean-continent transition (OCT) and in the outermost high. There are several alternative interpretations for the OCT and these highs in the South Atlantic salt basins; for example, Precambrian basement highs (Modica \& Brush 2004), intrusive and extrusive igneous rocks that formed drift basalts beyond the allochthonous salt tongue in Angola (Henry et al. 2007; Peebler et al. 2008), and exhumed mantle (Unternehr et al. 2010; Zalán et al. 2011).

A complete conjugate margin profile in the Gulf of Aden (Fig. 23) shows that the Neogene rift troughs in Somalia-Socotra and Yemen-Oman are quite narrow, and the OCT is marked by extensional faulting (d'Acremont et al. 2005; Autin et al. 2010; Leroy et al. 2010b). 
The OCT is also marked by rapid thinning of the crust (Leroy et al. 2004; Tiberi et al. 2007; Leroy et al. 2012) and high values of heat-flow (Lucazeau et al. 2008; Lucazeau et al. 2010; Watremez et al. 2011).

There is also an elevated basement high in the transition zone from continental to oceanic crust. Sedimentary troughs in these regions, adjacent to the outer high, are probably infilled by sediments younger than those located in more proximal syn-rift troughs, suggesting that rifting was progressively focused basinwards, advancing from the continental crust towards the incipient oceanic spreading center (Autin et al. 2010).

Oceanic crust is marked by symmetric magnetic anomalies relative to the present-day Sheba Ridge, which is characterized by a deep bathymetric depression and by extensional faults (Leroy et al. 2004; d'Acremont et al. 2006). A large magnetic anomaly marks this active oceanic spreading center (Sheba Ridge) that is separating the African from the Arabian plate in the Gulf of Aden (Cochran 1981; Leroy et al 2012). The continuation of magnetic anomalies from the offshore region towards the Gulf of Tadjura indicates that the Aden propagator is now advancing towards the Afar region, where massive Holocene volcanism and fault activity is registered both onshore and offshore.

\section{General model based on the Red Sea, Gulf of Aden and South Atlantic transects}

There is a large amount of geological and geophysical data for the Red Sea and the Gulf of Aden; however, in the Red Sea no regional penetrating deep seismic profile exists for the conjugate margins between the Nubian and the Arabian plates. Refraction data indicate the presence of crustal discontinuities such as the Conrad and the Moho discontinuities. The axial trough is floored by volcanic rocks and the spreading center is marked by a very high heat flow, indicative of active magma chambers underlying the ridge, and by organized magnetic anomalies that are symmetric ally distributed across the ridge, indicating reversals of the earth's magnetic field through breakup to early plate divergence time. The northern segment of the Red Sea and Gulf of Suez are characterized by rift structures extending from one margin to the other. Salt also forms a continuous layer across the conjugate margins. Spreading is only incipient, and punctiform oceanization by embryonic spreading centers might be the process of forming the continuous oceanic crust that is observed southwards.

The spreading center in the Gulf of Aden and in the central to southern Red Sea are characterized by an axial trough in water depths exceeding $2000 \mathrm{~m}$. The continental rift structures are not present in the main trough of the Red Sea, which is probably underlain by volcanic rocks related to the earliest spreading phases (proto-oceanic crust). The axial trough is marked by a protuberant ridge that may be associated with an oceanic propagator. In other regions, such as in the western Gulf of Aden, the ridge is associated with volcanoes and incipient seaward-dipping wedges may occur in the ocean-continent transition south of the city of Aden (Tard et al 1991; Leroy et al 2012). A very high heat flow and hydrothermal activity occurs in the axial troughs.

There is a marked asymmetry in the volcanic episodes registered in the Egyptian and Arabian side of the Red Sea, with most of the volcanic rocks intruded and extruded in the 
Arabian Plate. In the south, the Afar region is characterized by one of the largest LIPs in the world, probably related to a mantle plume. The Gulf of Suez and the shallow waters of the Red Sea are considered mature areas for petroleum exploration; however, the deep water region is a frontier area for exploration, and there are some similarities with the pre-salt structures observed in the South Atlantic, with possible pre-salt reservoirs sealed by massive stratified evaporates.

On the other hand, the breakup in the Iberian margin is marked by mantle exhumation, indicating a magma-poor margin preceding the continental breakup and formation of the oceanic crust. These two end-member models of continental breakup are related to propagation of extensional tectonics along strike and formation of oceanic crust at different regions in time. A general model for the continental breakup assuming propagation from south to north is presented on Fig. 24. This conceptual model, based on the observations discussed in this work, assumes an unthinned continental crust (tectonic domain A, locally affected by inherited structures from previous tectonic events), a rifted crust (tectonic domains $B$ and $C$, with proximal and distal rift basins) with extensional tectonics that evolved to form an incipient margin with an active spreading center (tectonic domain E). Transform fractures in oceanic crust probably used previous accommodation zones in the rift basins. The ocean-continent transition (tectonic domain $\mathrm{D}$ ) is marked by volcanic features in most margins, but in magma-poor margins exhumed mantle with peridotite ridges may occur.

A geological cross-section ( $X-Y$ on Fig. 24) shows a conceptual model for the early stages of continental separation for the South Atlantic, which could be compared to the Red Sea margins. The geological transect, based on the Espírito Santo - Kwanza conjugate margins in the Central South Atlantic (Fig. 25), extends from unthinned continental crust in the Brazilian margin (tectonic domain $A$ ) towards rifted crust ( $B$ and $C$ ), and crosses the continental-oceanic crust transition (D) and the active spreading center $(E)$, which separated the Espírito Santo basin from the Kwanza Basin after the continental breakup.

The model for the conjugate margins (Fig. 25) indicates an increase of volcanic activity at breakup followed by the abandonment of the main detachment and rift faults in the proximal basins, focusing the extension in the distal margin. The extensional system is interrupted by magmatic addition in the crust by dikes and extrusive lavas, which partially fill the distal syn-rift troughs. The continent-ocean transition is characterized by a magmatically accreted crust, and there is no exhumation phase because of high production of magma in the last phases of extension that preceded the emplacement of a spreading center. Finally, continental breakup resulted in symmetric magnetic anomalies associated with fully igneous crust separated by the active spreading center, ushering in the drift phase of the conjugate margins. Post-breakup magmatism is observed in several South Atlantic basins, indicating periods of increased mantle melting, particularly in regions near oceanic ridges that were affected by mantle plumes.

\section{Conclusions}

This work integrates geological and geophysical data in the Canadian-NW African and Iberian continental margins, which have been thoroughly investigated by research groups and 
petroleum companies, and compares their development with the more prolific Eastern Brazilian and West African margins, which have been extensively drilled during the past three decades, resulting in the discovery of several major hydrocarbon provinces. These margins were all developed in the Mesozoic, and may be compared with incipient oceanic basins that are in the embryonic stage in the Red Sea and slightly more evolved in the Gulf of Aden.

The breakup and divergence of the North American - NW African and the South American - West African continental plates in the Mesozoic is a direct consequence of opening the Central and South Atlantic oceans. From a tectonic perspective, three segments with different breakup histories can be identified. In segment 1, between the North American and the NW African margins, the breakup developed during the Jurassic, whereas the breakup in segment 2 developed during the Early Cretaceous, and in segment 3, between the Greenland and Norwegian margins, it developed during the Early Tertiary.

Several models have been discussed recently for the development of the conjugate margins, including pure shear, simple shear and mantle exhumation mechanisms. Some of these models impact the tectonic and thermal evolution of the sedimentary basins from the rifting to the spreading stages as there are some suggestions of lithospheric stretching and continental rifting extending into the post-salt sequence. Continental rifting is now regarded as a multi-phase process that may be aborted (as in the Recôncavo Basin onshore Brazil or in the Gulf of Suez) or evolve to breakup and formation of divergent margins (as has occurred along the Brazilian - West African margins or in the Gulf of Aden).

The South Atlantic and Central and North Atlantic rift systems display several characteristics that are common in divergent margins, such as the rift-phase controlled by extensional faults that is overlain by evaporites and then by shallow marine carbonate environments that grade into deep marine siliciclastic environments. South Atlantic rifting during the Early Cretaceous formed conjugate basins along the southeastern Brazilian and West African margins, resulting in deposition of lacustrine rocks that are much more oil-prolific than those of the Central and North Atlantic. The pre-salt sedimentary package is characterized by a belt of proximal syn-rift tilted blocks which are overlain by an extremely thick sag basin deposits in more distal areas. In the ultradeep water province of the Atlantic margins the pre-breakup structures are often obscured by thick salt and post-salt sedimentation; the Red Sea and the Gulf of Aden are natural laboratories for these processes as they are currently in the early stages of breakup and development.

Two end-member types of divergent margins are recognized in the Atlantic Ocean: the volcanic (magma-rich, corresponding to the majority of basins from Argentina to SE Brazil and their conjugates in West Africa) and non-volcanic (magma-poor) rifted margins, which may be represented by the northern Bahia basins (Camamu-Almada) and the Gabon Basin in West Africa. Most of these basins have been extensively drilled in the platform and deep water for petroleum exploration. However, only a few (e.g., Iberia and Newfoundland) have been sampled by ODP drill sites at the transition with oceanic crust. These sites targeted features that were alternatively interpreted as volcanic plugs, basement highs, tilted fault blocks, or as was proved by the boreholes, serpentinized peridotites or lherzolite ridges. These have not been proved in 
the South Atlantic or in the Gulf of Aden, but there is one small island in the Red Sea were peridotites may represent the sub-crustal rocks uplifted during the formation of the oceanic crust.

The Iberian model of continental breakup and mantle exhumation by detachment faults has recently been extensively used as an analog for the basins offshore Brazil and West Africa. However, it presents several fundamental differences to the sedimentary and tectonic processes envisaged for the South Atlantic and documented in the Red Sea-Gulf of Aden. Geological models for continental breakup and formation of oceanic crust have important implications for paleoenvironments, heat flow and petroleum systems, so these conceptual models necessitate calibration by robust interpretations based on geological and geophysical datasets, including profiles derived from deep penetrating seismic, gravity, magnetics, and where possible scientific drilling to sample rocks and measure their petrophysical properties.

The Red Sea and Gulf of Aden margins provide an analog for continental breakup in magma-rich regions that is more adequate than models based on the magma-poor IberiaNewfoundland margins. There are several similarities between the Red Sea and the Atlantic margins, particularly in terms of rift structures, sedimentary facies, pre-, syn- and post-rift volcanism, and the presence of massive evaporites in distal parts of the basins.

The Red Sea and the Gulf of Aden conjugate margins are in an incipient stage of oceanic crust development following continental crust breakup. Consequently, while the IberiaNewfoundland margin is an important and widely used analog for magma-poor margins, its applicability to South and Central Atlantic magma-rich margins is at best limited and questionable. The present-day Red Sea-Gulf of Aden magma-rich incipient spreading complex provides a valuable template to use in understanding various stages of the structural stratigraphic development and petroleum system evolution of magma-rich margins throughout the world.

\section{Acknowledgments}

We thank several colleagues at Petrobras, UERJ and several other institutions for enlightening discussions concerning the South Atlantic breakup processes. We acknowledge the important contributions by several geoscientists and explorationists, particularly Peter Szatmari, Sylvia dos Anjos, Alfredo Duarte, André Romanelli, Carlos Alves da Cunha Filho, Armando Guedes Vicentini and Alvaro Lucio de Oliveira Gomes. We also thank Neil Mitchell for providing high resolution seismic images of the Red Sea axial trough. Several research teams by ISTEP Univ Paris 06 and other institutions helped in the acquisition, processing and interpretation of regional seismic transects in the Gulf of Aden (ANR YOCMAL, Actions Marges) that provided the basis for the comparisons with the South Atlantic. Paul J. Post has kindly reviewed the first draft of the manuscript and contributed with several illuminating suggestions. We thank the critical reviews provided by Cindy Ebinger, and anonymous reviewer and Michal Nemcok, which greatly improved the manuscript. This work also benefitted from constructive suggestions provided by Naresh Kumar and David E. Brown. 


\section{References}

ALVES, T.M., MOITA, C., SANDNES, F., CUNHA, T., MONTEIRO, J.H. \& PINHEIRO, L.M. 2006. Mesozoic-Cenozoic evolution of North Atlantic continental-slope basins: The Peniche basin, western Iberian margin. Bulletin of the American Association of Petroleum Geologists, 90, 31-60.

ASSUMPÇÃO, M., DOURADO, J.C., RIBOTTA, L.C., MOHRIAK, W.U., DIAS, F.L. \& BARBOSA, J.R. 2011. The São Vicente earthquake of 2008 April and seismicity in the continental shelf off SE Brazil: further evidence for flexural stresses. Geophysical Journal International, 87, 1076-1088.

AUSTIN JR., J.A., TUCHOLKE, B.E. \& UCHUPI, E. 1989. Upper Triassic - Lower Jurassic salt basin southeast of the Grand Banks. Earth and Planetary Science Letters, 92, 357 - 370.

AUSTIN JR.,J.A., STOFFA, P.L., PHILLIPS, J D., OH, J., SAWYER, D.S., PURDY, G.M., REITER, E. \& MAKRIS, J. 1990. Crustal structure of the southeast Georgia embayment-Carolina trough: Preliminary results of a composite seismic image of a continental suture(?) and a volcanic passive margin. Geology, 18, 1023-1027.

AUTIN, J., LEROY, S., BESLIER, M. O., D'ACREMONT, RAZIN, E., P., RIBODETTI, A., BELLAHSEN, N., ROBIN, C. \& AL-TOUBI, K. 2010. Continental break-up history of a deep magma-poor margin from seismic reflection data (northeastern Gulf of Aden margin, offshore Oman). Geophysical Journal International, 180, 501-519, doi:10.1111/j.1365-246X.2009.04424.x.

BASSETTO, M., ALKMIN, F.F., SZATMARI, P. \& MOHRIAK, W.U. 2000. The oceanic segment of the southern Brazilian margin: morpho-structural domains and their tectonic significance. In: MOHRIAK, W.U. \& TALWANI, M. (eds.) Atlantic rifts and continental margins. American Geophysical Union Geophysical Monograph 115, 235-259.

BASTOW, I.D. \& KEIR, D. 2011. The protracted development of the continent-ocean transition in Afar. Nature Geoscience, 4, 248-250.

BASUYAU, C., TIBERI, C., LEROY, S., STUART, G., AL-LAZKI, A., AL-TOUBI, K. \& EBINGER, C. 2010. Evidence of partial melting beneath a continental margin: case of Dhofar, in the Northern Gulf of Aden (Sultanante of Oman). Geophysical Journal International, 180, 520-534.

BESLIER, M.O., ASK, M. \& BOILLOT, G., 1993. Ocean-continent boundary in the lberial abyssal plain from multichannel seismic data. Tectonophysics,.218, 383-393.

BEYDOUN, Z.R. 1989. The hydrocarbon prospects of the Red Sea - Gulf of Aden: a review. Journal of Petroleum Geology, 12, 125-44.

BLAICH, O.A., FALEIDE, J.I. \& TSIKALAS, F. 2011. Crustal breakup and continent-ocean transition at South Atlantic conjugate margins. Journal of Geophysical Research, 116, B01402, doi:10.1029/2010JB007686.

BOHANNON, R.G. 1989. Style of extensional tectonism during rifting, Red Sea and Gulf of Aden. Journal of African Earth Sciences, 8, 589-602.

BOILLOT, G., BESLIER, M.O., KRAWCZYK, C.M., RAPPIN, D. \& RESTON, T.J. 1995. The formation of passive margins: constraints from the crustal structure and segmentation of the deep Galicia margin, Spain. Geological Society, London, Special Publications, 90, 71 - 91.

BOILlot, G., GRIMAUD, S., MAUfFRET, A. MOUGENOT, D., KORNPROBST, J., MERGOILDANIEL, J. \& TORRENT, G. 1980. Ocean-continent boundary off the lberian margin: a serpentinite diapir west of the Galicia Bank. Earth \& Planetary Science Letters, 48, 23-34.

BONATTI, E. 1985. Punctiform initiation of seafloor spreading in the Red Sea during transition from a continental to an oceanic rift. Nature, 316, 33 - 37.

BONATTI, E., HAMLYN, P. \& OTTONELLO, G. 1981. Upper mantle beneath a young oceanic rift: 
peridotites from the Island of Zabargad (Red Sea). Geology, 9, 474-479.

BONATTI, E., CLOCCHIATTI, R., COLANTONI, P., GELMINI, R., MARINELLI, G., OTTONELLO, G., SANTACROCE, R., TAVIANI, A., ABDEL-MEGUID, A.A., ASSAF, H.S. \& EL TAHIR M.A. 1983. Zabargad (St. John's) Island: an uplifted fragment of sub-Red Sea lithosphere. Journal of the Geological Society, 140, 677-690.

BONATTI, E., OTTONELLO, G. \& HAMLYN, P.R. 1986. Peridotites from the Island of Zabargad (St. John), Red Sea: petrology and geochemistry. Journal of Geophysical Research, 91, B1, 599-631.

BOSENCE, D.W.J. 1998. Stratigraphic and sedimentological models of rift basins. In: PURSER B.H. \& BOSENCE, D.W.J. (eds) Sedimentation and Tectonic of rift basins: Red Sea-Gulf of Aden. Chapman \& Hall, London, Chapter A2, 9-25.

BOSWORTH, W., HUCHON, P., \& MCCLAY, K. 2005. The Red Sea and Gulf of Aden basins. Journal of African Earth Sciences, 43, 334-378.

BOTT, W.F., SMITH, B.A., OAKES, G., SIKANDER, A.H. \& IBRAHIM, A.I. 1992. The tectonic framework and regional hydrocarbon prospectivity of the Gulf of Aden. Journal of Petroleum Geology, 15, 211-243.

BOWLING, J.C. \& HARRY, D.L. 2001. Geodynamic models of continental extension and the formation of non-volcanic rifted continental margins. In: WILSON, R.C.L., WHITMARSH, R.B., TAYLOR, B. \& FROITZHEIM, N. (eds) Non-Volcanic rifting of continental margins: A comparison of evidence from land and sea. Geological Society of London, Special Publications, 187, 511-536.

BP 2011. Statistical Review of World Energy June 2011.

BROWN, D.E., MOHRIAK, W.U., JABOUR, H. \& TARI, G. 2008. Central and South Atlantic Conjugate Margins Pre- and Post-Salt Successions: Recognition, Definition and Implications to Rift Models and Petroleum Systems. American Association of Petroleum Geologists International Conference \& Exhibition, October 26-29, 2008; Cape Town, South Africa, Extended Abstracts CD, 1p. http://www.searchanddiscovery.net/documents/2009/30081brown/ndx_brown.pdf

BUENO, G.V. 2004. Diacronismo de eventos no rifte Sul-Atlântico. Boletim de Geociências da Petrobras, Rio de Janeiro, 12, (2), 203-229.

CARMINATTI, M., WOLFF, B. \& GAMBOA, L.A.P. 2008. New exploratory frontiers in Brazil. 19th World Petroleum Congress, Madrid, Spain, WPC Proceedings, Abstracts CD, 11p.

CASADO, C.L., GALDEANO, C.S., PALACIOS, S.M. \& ROMERO, J.H. 2001. The structure of the Alboran Sea: an interpretation from seismological and geological data. Tectonophysics, 338, 79-95.

CHANG, H.K., KOWSMANN, R.O., FIGUEIREDO, A.M.F., \& BENDER, A.A. 1992. Tectonic and stratigraphy of the East Brazil Rift System: an overview. Tectonophysics, 213, 97-138.

CHAZOT, G., MENZIES, M.A. \& BAKER, J. 1998. Pre-, syn- and post-rift volcanism on the southwestern margin of the Arabian plate. In: BOSENCE, D.J.W \& PURSER, B.H. (eds) Sedimentation and Tectonic of rift basins: Red Sea - Gulf of Aden. Chapman \& Hall, London, Chapter B2, 50-55.

CHIAN, D., LOUDEN, K.E., MINSHULL, T.A. \& WHITMARSH, R.B. 1999. Deep structure of the oceancontinent transition in the southern Iberia Abyssal Plain from seismic refraction profiles, Ocean Drilling Program (Legs 149 and 173) transect. Journal of Geophysical Research, 104, 7443-7462.

COBBOLD, P.R., SZATMARI, P., DEMERCIAN, L.S., COELHO, D. \& ROSSELLO, E.A. 1995. Seismic experimental evidence for thin-skinned horizontal shortening by convergent radial gliding on evaporites, deep-water Santos Basin. In: JACKSON, M.P.A., ROBERTS, R.G. \& SNELSON S. (eds.), Salt tectonics: a global perspective. American Association of Petroleum Geologists, Memoir 65, 305321.

COCHRAN, J.R. 1981. The Gulf of Aden: structure and evolution of a young ocean basin and continental margin. Journal of Geophysical Research, 86, 263-287.

COCHRAN, J.R. 1982. The magnetic quiet zone in the eastern Gulf of Aden: implications for the early 
development of the continental margin. Geophysical Journal of the Royal Astronomical Society, 68, 171-201.

COCHRAN, J.R. 1983. A model for development of Red Sea. Bulletin of the American Association of Petroleum Geologists, 67, 41-69.

COCHRAN, J.R. 2005. Northern Red Sea: Nucleation of an oceanic spreading center within a continental rift. Geochemistry, Geophysics, Geosystems, 6, Q03006, doi:10.1029/2004GC000826.

COCHRAN, J.R. \& KARNER, G. D. 2007. Constraints on the deformation and rupturing of continental lithosphere of the Red Sea: the transition from rifting to drifting. Geological Society of London, Special Publications, 282, 265-289.

COCHRAN, J.R. \& MARTINEZ, F. 1988. Evidence from the northern Red Sea on the transition from continental to oceanic rifting. Tectonophysics, 153, 25-53.

D'ACREMONT, E., LEROY, S., BESLIER, M.O., BELLAHSEN, N., FOURNIER, M., ROBIN, C., MAIA, M. \& GENTE, P. 2005. Structure and evolution of the eastern Gulf of Aden conjugate margins from seismic reflection data. Geophysical Journal International, 160, 869-890.

D'ACREMONT, E., LEROY, S., MAIA, M., PATRIAT, P., BESLIER MARIE, O., BELLAHSEN, N., FOURNIER, M. \& GENTE, P. 2006. Structure and evolution of the eastern Gulf of Aden; insights from magnetic and gravity data (Encens-Sheba MD117 cruise). Geophysical Journal International, 165, 786803.

D'ACREMONT, E., LEROY, S., MAIA, M., GENTE, P. \& AUTIN, J. 2010. Volcanism, jump and propagation on the Sheba Ridge, eastern Gulf of Aden: Segmentation evolution and implications for accretion processes. Geophysical Journal International, 180, 535-551.

DAVISON, I. 1997. Wide and narrow margins of the Brazilian South Atlantic. Journal of the Geological Society of London, 154, 471-476.

DAVISON, I. 1999. Tectonics and hydrocarbon distribution along the Brazilian South Atlantic margin. In: CAMERON, N.R., BATE, R.H. \& CLURE, V.S. (eds) The Oil and Gas Habitats of the South Atlantic. Geological Society of London, Special Publications, 153, 133-151.

DAVISON, I. 2005. Central Atlantic margin basins of North West Africa: Geology and hydrocarbon potential (Morocco to Guinea). Journal of African Earth Sciences, 43, 254-274.

DAVISON, I., AL-KADASI, M., AL-KHIRBASH, S., AL-SUBBARY, A., BAKER, J. BLAKEY, S., BOSENCE, D., DART, C., HEATON, R., MCCLAY, K., MENZIES, M., NICHOLS, G., OWEN, L. \& YELLAND, A. 1994. Geological evolution of the southeastern Red Sea rift margin: Republic of Yemen. Geological Society of America Bulletin, 106, 1474-1493.

DAVISON, I., BOSENCE, D., ALSOP, I. \& AL-AAWAH, M.H. 1995. Deformation and sedimentation above and below Miocene salt diapirs and their overhangs, NW Yemen. In: TRAVIS, C.J., HARRISON, H., HUDEC, M.R., VENDEVILLE, B.C., PEEL F.J. \& PERKINS, R.E. (eds) Salt, Sediment and Hydrocarbons, 33-40.

DAVISON, I., BOSENCE, D., ALSOP, I. \& AL-AAWAH, M.H. 1996. Deformation and sedimentation around active Miocene salt diapirs on the Tihama Plain, northwest Yemen. In: ALSOP, I., BLUNDELL, D.J. \& DAVISON, I. (eds) Salt Tectonics. Geological Society of London, 100, 23-39.

DAVISON, I., TATNELL, M.R., OWEN, L.A., JENKINS, G. \& BAKER, J. 1998. Tectonic geomorphology and rates of crustal processes along the Red Sea margin, north-west Yemen. In: PURSER, B., AND BOSENCE, D. (eds) Sedimentation and Rift Tectonics of Rift Basins: Red Sea-Gulf of Aden. Chapman and Hall, London, 595-612.

DEMERCIAN, L.S., SZATMARI, P. \& COBBOLD, P.R. 1993. Style and pattern of salt diapirs due to thin-skinned gravitational gliding, Campos and Santos basins, offshore Brazil. Tectonophysics, 228, 393-433.

DIREEN, N.G., STAGG, H.M.J., SYMONDS, P.A. \& COLWELL J. B. 2011. Dominant symmetry of a conjugate southern Australian and East Antarctic magma-poor rifted margin segment. Geochemistry, 
Geophysics, Geosystems, 12, Q02006, doi:10.1029/2010GC003306

DISCOVERY WORKING GROUP 1998. Deep structure in the vicinity of the ocean-continent transition zone under the southern Iberia abyssal plain. Geology, 26, 743-746.

EBINGER, C.J., KEIR, D., AYELE, A., CALAIS, E., WRIGHT, T.J., BELACHEW, M., HAMMOND, J.O.S., CAMPBELL, E. \& BUCK, W.R. 2008. Capturing magma intrusion and faulting processes during continental rupture: seismicity of the Dabbahu (Afar) rift. Geophysical Journal International, 174, 11381152.

EGLOFF, F., RIHM, R., MAKRIS, J., IZZELDIN, Y.A., BOBSIEN, M., MEIR, K., JUNGE, P., NOMAN, T. \& WARSI, W. 1991. Contrasting structural styles of the eastern and western margins of the southern Red Sea: the 1988 SONNE experiment. Tectonophysics, 198, 329-353.

ENACHESCU, M.E. 1988. Extended basement beneath the intracratonic rifted basins of the Grand Banks of Newfoundland. Canadian Journal of Exploration Geophysics, 24, 48-65.

FAINSTEIN, R., 2008. Sub-salt and post-salt reservoirs. T\&B Petroleum, 25, 58-64.

FANTOZZI, P.L.1996. Transition from continental to oceanic rifting in the Gulf of Aden: structural evidence from field mapping in Somalia and Yemen. Tectonophysics, 259, 285-311.

FORMIGLI, J. 2007. Pre-Salt Reservoirs Offshore Brazil: Perspectives and Challenges. Bank of America Energy Conference, 21p. http://www2.petrobras.com.br/ri/pdf/2007_Formigli_Miami_presal.pdf

FOURNIER, M., HUCHON, P., KHANBARI, K. \& LEROY S. 2007. Segmentation and along-strike asymmetry of the passive margin in Socotra, eastern Gulf of Aden: Are they controlled by detachment faults? Geochemistry, Geophysics, Geosystems, 8, 1-17.

FOURNIER, M., CHAMOT-ROOKE, N., PETIT, C., HUCHON, P., AL-KATHIRI, A., AUDIN, L., BESLIER, M.-O., D'ACREMONT, E., FABBRI, O., FLEURY, J.-M., KHANBARI, K., LEPVRIER, C., LEROY, S., MAILLOT, B. \& MERKOURIEV, S. 2010. Arabia-Somalia plate kinematics, evolution of the Aden-Owen-Carlsberg triple junction, and opening of the Gulf of Aden. Journal of Geophysical Research, 115, B04102.

FRANKE, D., NEBEN, S., LADAGE, S., SCHRECKENBERGER, B. \& HINZ, K. 2007. Margin segmentation and volcano-tectonic architecture along the volcanic margin off Argentina/Uruguay, South Atlantic. Marine Geology, 244, 46-67.

FRANKE, D., LADAGE, S., SCHNABEL, M., SCHRECKENBERGER, B., REICHERT, C., HINZ, K., PATERLINI, M., ABELLEYRA, J. \& SICILIANO, M. 2010. Birth of a volcanic margin off Argentina, South Atlantic. Geochemistry, Geophysics, Geosystems, 11, Q0AB04, doi:10.1029/2009GC002715.

GAMBOA, L.A.P. \& RABINOWITZ, P.D. 1984. The evolution of the Rio Grande Rise in the Southwest Atlantic Ocean. Marine Geology, 58, 35-58.

GLADCZENKO, T.P., HINZ, K., ELDHOLM, O., MEYER, H., NEBEN, S. \& SKOGSEID, J. 1997. South Atlantic volcanic margins. Journal of the Geological Society of London, 154, 465-470.

GOMES, P.O., KILSDONK, B., MINKEN, J., GROW, T. \& BARRAGAN, R. 2008. The outer high of the Santos Basin, Southern São Paulo Plateau, Brazil: pre-salt exploration outbreak, paleogeographic setting, and evolution of the syn-rift structures. American Association of Petroleum Geologists International Conference and Exhibition, Cape Town, South Africa, October 26-29, 2008, Abstracts CD, 6p. http://www.searchanddiscovery.net/documents/2009/10193gomes/images/gomes.pdf

HAYWARD, N.J. \& EBINGER, C.J. 1996. Variations in the along-axis segmentation of the Afar Rift system. Tectonics, v. 15, n.2, p.244-257.

HENRY, S.G., DANFORTH, A., TARI, G. \& VENKATRAMAN, S. 2007. Pre-Salt and Salt Geometry as Controlling Factors in Post-Salt Tectonics. First MAPG International Conference \& Exhibition, October 28-31, 2007, Marrakech, Morocco. Poster Session, Abstract.

http://www.searchanddiscovery.com/documents/2008/08006morocco_abs 
HENRY, S.G., KUMAR, N., \& VENKATRAMAN, S. 2009. New pre-salt insight. GeoExpro, 6, (5), 46-48. HEY, R., DUENNEBIER, F.K. \& MORGAN, W. J. 1980. Propagating rifts on mid-ocean ridges. Journal of Geophysical Research, 85, 3647-3658.

HINZ, K., ELDHOLM, O., BLOCK, M. \& SKOGSEID, J. 1993. Evolution of North Atlantic volcanic continental margins. In: PARKER, J.R. (ed.) Petroleum Geology of Northwest Europe, Proceedings of the 4th Conference, Geological Society of London, 2, 901-913.

HINZ, K., NEBEN, S., SCHRECKENBERGER, B., ROESER, H.A., BLOCK, M., SOUZA, K.G. \& MEYER, H. 1999. The Argentine continental margin north of $48^{\circ} \mathrm{S}$ : sedimentary successions, volcanic activity during breakup. Marine and Petroleum Geology, 16, 1-25.

HUISMANS, R. \& BEAUMONT, C. 2011. Depth-dependent extension, two-stage breakup and cratonic underplating at rifted margins. Nature, 473, 74-79, doi:10.1038/nature09988

JACKSON, M.P.A. \& VENDEVILLE, B.C. 1994. Regional extension as a geologic trigger for diapirism. Geological Society of America Bulletin, 106, 57-73.

JACKSON, M.P.A., CRAMEZ, C. \& FONCK, J.M. 2000. Role of subaerial volcanic rocks and mantle plumes in creation of South Atlantic margins: implications for salt tectonics and source rocks. Marine and Petroleum Geology, 17, 477-498.

JAHNERT, R., FRANÇA, A., TRINDADE, L., QUINTAES, C., SANTOS, P., PESSOA, J., \& BEDREGAL, R. 1998. The petroleum system of Campos Basin. In: Mello, M.R. \& Yilmaz, P.O. (eds.), Extended Abstract Volume, 1998 AAPG International Conference and Exhibition, Rio Janeiro, Brazil, 600-601.

KARNER, G.D. 2008. Depth-dependent extension and mantle exhumation: an extreme passive margin end-member or a new paradigm? In: BROWN, D.E. \& WATSON, N. (eds) Extended Abstracts - Central Atlantic Conjugate Margins Conference, Halifax 2008. 10-16.

KARSON, J.A., COLLINS, J.A., \& CASEY, J.F. 1984. Geologic and seismic velocity structure of the crust/mantle transition in the Bay of Islands Ophiolite Complex. Journal of Geophysical Research, 89, B7, 6126-6138.

KEEN, C.E. \& POTTER, D.P. 1995. The transition from a volcanic to a non-volcanic rifted margin off eastern Canada. Tectonics, 14, 359-371.

KIDSTON, A.G., BROWN, D.E., SMITH, B.M. \& ALTHEIM, B., 2002. Hydrocarbon Potential of the Deep-Water Scotian Slope. Canada-Nova Scotia Offshore Petroleum Board, Halifax, 111p. CD-ROM and www.cnsopb.ns.ca/resources/assessment.html

KUMAR, N. \& GAMBOA, L.A.P. 1979. Evolution of the São Paulo Plateau (southeastern Brazilian margin) and implications for the early history of the South Atlantic. Geological Society of America Bulletin, 90, 281-293.

LENTINI, M.R., FRASER, S.I., SUMNER, H.S. \& DAVIES, R.J. 2010. Geodynamics of the central South Atlantic conjugate margins: implications for hydrocarbon potential. Petroleum Geosciences, 16, 217-229.

LEROY, S., GENTE, P., FOURNIER, M., D'ACREMONT, E., PATRIAT, P., BESLIER, M.O., BELLAHSEN, N., MAIA, M., ANGELINA BLAIS, A., PERROT, J., AL-KATHIRI, A., MERKOURIEV, S., JEAN-MARC FLEURY, RUELLAN, P.Y., CLAUDE LEPVRIER, C. \& HUCHON, P. 2004. From rifting to spreading in the eastern Gulf of Aden: A geophysical survey of a young oceanic basin from margin to margin. Terra Nova, 16, 185-192, doi:10.1111/j.1365-3121.2004.00550.x.

LEROY, S., D'ACREMONT, E., TIBERI, C., BASUYAU, C., AUTIN, J., LUCAZEAU, F., \& SLOAN, H. 2010a. Recent off-axis volcanism in the eastern Gulf of Aden: implications for plume-ridge interaction. Earth Planetary Science Letters, 293, 140-153. doi:10.1016/j.epsl.2010.02.036.

LEROY, S., LUCAZEAU, F., D'ACREMONT, E., WATREMEZ, L., AUTIN, J., ROUZO, S., BELLAHSEN, N., TIBERI, C., EBINGER, C., BESLIER, M.O., PERROT, J., RAZIN, P., ROLANDONE, 
F., SLOAN, H., STUART, G., AL LAZKI, A., AL-TOUBI, K., BACHE, F., BONNEVILLE, A., GOUTORBE, B., HUCHON, P., UNTERNEHR, P. \& KHANBARI, K. 2010b. Contrasted styles of rifting in the eastern Gulf of Aden: A combined wide-angle, multichannel seismic, and heat flow survey. Geochemistry, Geophysics, Geosystems, 11, 1-14, Q07004, doi:10.1029/2009GC002963.

LEROY, S., RAZIN, P., AUTIN, J., BACHE, F., ACREMONT, E., WATREMEZ, L., ROBINET, J., BAURION, C., DENĖLE, Y., BELLAHSEN, N., LUCAZEAU, F., ROLANDONE, F., ROUZO, S., KIEL, J.S., ROBIN, C., GUILLOCHEAU, F., TIBERI, C., BASUYAU, C., BESLIER, M.O., EBINGER, C., STUART, G., AHMED, A., KHANBARI, K., GANAD, I., CLARENS, P., UNTERNEHER, P., TOUBI, K. \& LAZKI, A.A. 2012. From rifting to oceanic spreading in the Gulf of Aden: a synthesis. Arabian Journal of Geosciences, 1-43, DOI 10.1007/s12517-011-0475-4.

LIGI, M., BONATTI, E., TONTINI, F.C., CIPRIANI, A., COCCHI, L., SCHETTINO, A., BORTOLUZZI, G., FERRANTE, V., KHALIL, S., MITCHELL, N.C. \& RASUL, N. 2011. Initial burst of oceanic crust accretion in the Red Sea due to edge-driven mantle convection. Geology, 39, 1019-1022. doi:10.1130/G32243.1

LISTER, G.S., ETHERIDGE, M.A. \& SYMONDS, P.A. 1986. Detachment faulting and the evolution of passive continental margins. Geology, 14, 246-250.

LOWELL, J.D. \& GENIK, G.J. 1972. Sea-floor spreading and structural evolution of the southern Red Sea. Bulletin of the American Association of Petroleum Geologists, 56, 247-259.

luCAZEAU, F., LeROY, S., AUtin, J., BONNEVILle, A., GOUTORBE, B., ROLANDONE, F., D'ACREMONT, E., WATREMEZ, L., DÜSÜNUR, D., \& HUCHON, P. 2009. Post-Rift Volcanism and high heat-flow at the Ocean-Continent Transition of the Gulf of Aden. Terra Nova, 21, 285-292.

LUCAZEAU, F., LEROY, S., BONNEVILLE, A., GOUTORBE, B., ROLANDONE, F., D'ACREMONT, E., WATREMEZ, L., DÜSÜNUR, D., TUCHAIS, P., HUCHON, P., BELLAHSEN, N., \& AL-TOUBI, K. 2008. Persistent thermal activity at the Eastern Gulf of Aden after continental break-up. Nature Geosciences, 854-858.

LUCAZEAU, F., LEROY, S., ROLANDONE, F., D'ACREMONT, E., WATREMEZ, L., BONNEVILLE, A., GOUTORBE, B., DÜSÜNUR, D., 2010. Heat-flow and hydrothermal circulations at the OceanContinent Transition of the Eastern Gulf of Aden. Earth Planetary Science Letters, 295, 554-570.

LUHESHI, M., ROBERTS, D.G, NUNN, K., MAKRIS, J., COLLETTA, B., WILSON, H., MONNIER, F., RABARY, G. \& DUBILLE, M. 2012. The impact of conjugate margins analysis on play fairway evaluation - an analysis of the hydrocarbon potential of Nova Scotia. First Break, 30, 61-72.

MACDONALD, D., GOMEZ-PEREZ, I., FRANZESE, J., SPALLETTI, L., LAWVER, L., GAHAGAN, L., DALZIEL, I., THOMAS, C., TREWIN, N., HOLE, M. \& PATON, D. 2003. Mesozoic break-up of SW Gondwana: implications for regional hydrocarbon potential of the southern South Atlantic. Marine and Petroleum Geology, v. 20, p. 287-308.

MALDONADO, A., SOMOZA, L. \& PALLARÉS, L. 1999. The Betic Orogen and the Iberian-African boundary in the Gulf of Cadiz: geological evolution (central North Atlantic). Marine Geology, 155, 0943.

MANATSCHAL, G. \& BERNOULLI, D. 1998. Rifting and early evolution of ancient ocean basins: the record of the Mesozoic Tethys and of the Galicia-Newfoundland margins. Marine Geophysical Research, 20, 371-381.

MANIGHETTI, I., TAPPONNIER, P., GILLOT, P.Y., JACQUES, E., COURTILLOT, V., ARMIJO, R., RUEGG, J.C. \& KING, G. 1998. Propagation of rifting along the Arabia-Somalia plate boundary: into Afar. Journal of Geophysical Research, 103, B3, 4947-4974.

MARTINEZ, F. \& COCHRAN, J.R. 1988. Structure and tectonics of the northern Red Sea: catching a continental margin between rifting and drifting. Tectonophysics, 150, 1-32.

MITCHELL, N.C., LIGI, M., FERRANTE, V., BONATTI, E., \& RUTTER, E. 2010. Submarine salt flows in the central Red Sea. Geological Society of America Bulletin, 122, 701-713. 
MIZUSAKI, A.M.P., THOMAZ-FILHO, A., MILANI, E.J. \& CÉSERO, P. 2002. Mesozoic and Cenozoic igneous activity and its tectonic control in northeastern Brazil. Journal of South American Earth Sciences, 15, 183-198.

MODICA, C.J. \& BRUSH, E.R. 2004. Postrift sequence stratigraphy, paleogeography, and fill history of the deep-water Santos Basin, offshore southeast Brazil. Bulletin of the American Association of Petroleum Geologists, 88, 923-946.

MOHRIAK, W.U., 2001. Salt tectonics, volcanic centers, fracture zones and their relationship with the origin and evolution of the South Atlantic Ocean: geophysical evidence in the Brazilian and West African margins. 7th International Congress of the Brazilian Geophysical Society, Salvador-BahiaBrazil, October 28-31, 2001, Expanded Abstract, 1594-1597.

MOHRIAK, W.U. 2003. Bacias sedimentares da margem continental Brasileira. In: BIZZA, L.A., SCHOBBENHAUS, C., VIDOTTII, R.M. \& GONÇALVES, J.H. (eds) Geología, Tectônica e Recursos Minerais do Brasil. Chapter III, 87-165, CPRM, Brasília, Brazil.

MOHRIAK, W.U. 2004. Recursos energéticos associados à ativação tectônica mesozóico-cenozóica da América do Sul. In: MANTESSO NETO, V., BARTORELLI, A., CARNEIRO, C.D.R. \& BRITONEVES, B.B. (eds) Geologia do continente sul-americano: evolução da obra de Fernando Flávio Marques de Almeida. Beca Produções Culturais Ltda., São Paulo, Chapter XVIII, 293-318.

MOHRIAK, W.U. 2005. Salt tectonics in Atlantic-type sedimentary basins: Brazilian and West African perspectives applied to the North Atlantic Margin. In: POST, P.J., ROSEN, N.C., OLSON, D.L., PALMES, S.L., LYONS, K.T. \& NEWTON, G.B. (eds) Petroleum Systems of Divergent Continental Margin Basins. GCSSEPM 25th Annual Bob F. Perkins Research Conference, Houston, Texas, 375413.

MOHRIAK, W.U. 2011. Continental breakup, magmatism and the role of propagators: insights from the South Atlantic and the Red Sea-Gulf of Aden conjugate margins. Gondwana 14, Abstracts, Session GBR-03.01.21. Rio de Janeiro-Buzios, September 25-30, 2011.

MOHRIAK, W.U., BROWN, D.E. \& TARI, G. 2008. Sedimentary Basins in the Central and South Atlantic Conjugate Margins: Deep Structures and Salt Tectonics. In: BROWN, D.E. \& WATSON, N. (eds) Extended Abstracts: Central Atlantic Conjugate Margins Conference - Halifax 2008. CD, 89-102.

MOHRIAK, W.U., CUNHA FILHO, C.A., VICENTINI, A.G. \& GOMES, A.L. 2010Aa. Modelo geofísico de ruptura continental em bacia evaporítica: o caso histórico do Mar Vermelho. Simpósio de Geofísica da Petrobras, Boletim de Resumos Expandidos, 6p.

MOHRIAK, W.U., ROSENDAHL, B.R., TURNER, J.P. \& VALENTE, S.C. 2002. Crustal architecture of South Atlantic volcanic margins. In: MENZIES, M.A., KLEMPERER, S.L., EBINGER, C.J. \& BAKER, J. (eds) Volcanic Rifted Margins. Geological Society of America Special Paper, 362, 159-202.

MOHRIAK, W.U., NÓBREGA, M., ODEGARD, M.E., GOMES, B.S. \& DICKSON, W.G. $2010 \mathrm{~b}$. Geological and geophysical interpretation of the Rio Grande Rise, south-eastern Brazilian margin: extensional tectonics and rifting of continental and oceanic crusts. Petroleum Geoscience, 16, 231245.

MONIN, A.S., LITVIN, V.M., PODRAZHANSKY, A.M., SAGALEVICH, A.M., SOROKHTIN, O.G., VOITOV, V.I., YASTREBOV, V.S. \& ZONENSHAIN, L.P. 1982. Red Sea Submersible Research Expedition. Deep Sea Research Part A. Oceanographic Research Papers, 29, 361-373.

MONTENAT, C., OTT D'ESTEVOU, P., PURSER, B.H., BUROLLET, P.F., JARRIGE, J.J.,ORSZAGSPERBER, F., PHILOBBOS, E., PLAZIAT, J.C., PRAT, P., RICHERT, J.P., ROUSSEL, N. \& THIRIET, J.P. 1988. Tectonic and sedimentary evolution of the Gulf of Suez and the northwestern Red Sea. Tectonophysics, 153, 161-173.

MOULIN, M., ASLANIAN, D. \& UNTERNEHR, P. 2010. A new starting point for the South and Equatorial Atlantic Ocean. Earth-Science Reviews, 98, 1-37. 
OETR ASSOCIATION, 2011. Play Fairway Analysis Atlas-Offshore Nova Scotia. Nova Scotia Department of Energy Report, NSDOE Records Storage File No.88-11-0004-01, 347p. http://www.offshoreenergyresearch.ca/OETR/OETRPlayFairwayProgramMainPage/tabid/402/Default.a $\operatorname{spx}$

OH, J., AUSTIN, J.A., PHILLIPS, J.D., COFFIN, M.F. \& STOFFA, P.L. 1995. Seaward-dipping reflectors offshore the southeastern United States: seismic evidence for extensive volcanism accompanying sequential formation of the Carolina trough and Blake Plateau basin. Geology, 23, 9-12.

OMAR, G.I. \& STECKLER, M.S. 1995. Fission Track Evidence on the Initial Rifting of the Red Sea: Two Pulses, No Propagation. Science, 270, 1341-1344. DOI: 10.1126/science.270.5240.1341.

PEEBLER, R. 2008. Where to from Here? Leveraging technology to address the supply challenge. Hyderabad 2008 Conference, India, 50p.

PÉRON-PINVIDIC, G. \& MANATSCHAL, G. 2008. The final rifting evolution at deep magma-poor passive margins from lberia-Newfoundland: a new point of view. International Journal of Earth Sciences (Geol. Rundsch.), doi:10.1007/s00531-008-0337-9.

PÉRON-PINVIDIC, G.,,MANATSCHAL, G., MINSHULL, T.A. \& SAWYER, D.S. 2007.

Tectonosedimentary evolution of the deep Iberia-Newfoundland margins: Evidence for a complex breakup history. Tectonics, 26, TC2011, doi:10.1029/2006TC001970.

PURSER, B.H. \& HOTZL, H. 1988. The sedimentary evolution of the Red Sea rift: a comparison of the northwest (Egyptian) and the northeast (Saudi Arabian) margins. Tectonophysics, 153, 193-208.

RABINOWITZ, P.D. \& LABRECQUE, V. 1979. The Mesozoic South Atlantic Ocean and evolution of its continental margins. Journal of Geophysical Research, 84, 5973-6020.

RESTON, T.J., KRAWCZYK, C.M. \& KLAESCHEN, D. 1996. The S reflector west of Galicia (Spain): evidence from prestack depth migration for detachment faulting during continental breakup. Journal of Geophysical Research, 101, B4, 8075-8091.

RIHM, R. \& HENKE, C.H. 1998. Geophysical studies on early tectonic controls on Red Sea rifting, opening and segmentation. In: BOSENCE, D.W.J. \& PURSER, B.H. (eds) Sedimentation and Tectonic of rift basins: Red Sea-Gulf of Aden. Chapman \& Hall, London, Chapter B1, 29-49.

ROSENDAHL, B. R., MOHRIAK, W.U., ODEGARD, M.E., TURNER, J.P. \& DICKSON, W.G. 2005. West African and Brazilian Conjugate Margins: Crustal Types, Architecture, and Plate Configurations. In: POST, P.J., ROSEN, N.C., OLSON, D.L., PALMES, S.L., LYONS, K.T. \& NEWTON, G.B. (eds) Petroleum Systems of Divergent Continental Margin Basins. GCSSEPM 25th Annual Bob F. Perkins Research Conference, Houston, Texas, 261-317.

ROY, P.L. \& PIQUÉ, A. 2001. Triassic-Liassic Western Moroccan synrift basins in relation to the Central Atlantic opening. Marine Geology, 172, 359-381.

SAMUEL, M.A., HARBURY, N., BOTT, R. \& TA, M. 1997. Field observations from the Socotran platform: their interpretation and correlation to Southern Oman. Marine and Petroleum Geology, 14, 661-673.

SAVOYAT, E., SHIFERAW, A. \& BALCHA, T. 1989. Petroleum exploration in the Ethiopian Red Sea. Journal of Petroleum Geology, 12, 187-204.

SCHETTINO, A. \& TURCO, E. 2009. Breakup of Pangaea and plate kinematics of the central Atlantic and Atlas regions. Geophysical Journal International, 178, 1078-1097.

SCOTCHMAN, I.C., GILCHRIST, G., KUSZNIR, N.J., ROBERTS, A.M. \& FLETCHER, R. 2010. The breakup of the South Atlantic Ocean: formation of failed spreading axes and blocks of thinned continental crust in the Santos Basin, Brazil and its consequences for petroleum system development. In: VINING, B.A. \& PICKERING, S.C. (eds) Petroleum Geology: From Mature Basins to New Frontiers. Proceedings of the 7th Petroleum Geology Conference, Geological Society of London, 855-866, doi: $10.1144 / 0070855$. 
SHERIDAN, R.E., MUSSER, D.L., GLOVER, L., TALWANI, M., EWING, J.I., HOLBROOK, W.S., PURDY, G.M., HAWMAN, R. \& SMITHSON, S. 1993. Deep seismic reflection data of EDGE U.S. midAtlantic continental margin experiment: implications for Appalachian sutures and Mesozoic rifting and magmatic underplating. Geology, 21, 563-567.

SIBUET, J.C. 1992. New constraints on the formation of the non-volcanic continental Galicia - Flemish Cap conjugate margins. Journal of the Geological Society, London, 149, 829-840.

SZATMARI, P. \& MILANI, E.J. 1999. Microplate rotation in northeast Brazil during South Atlantic rifting: analogies with the Sinai microplate. Geology, 27, 1115-1118.

TANKARD, A. J., ULIANA, M. A. ,WELSINK, H. J., RAMOS,V. A., TURIC, M., FRANÇA, A. B., MILANI, E. J. , NEVES, B. B. DE BRITO, EYLES, N., SKARMETA, J., SANTA ANA, H., WIENS, F., CIRBIÁN, M., PAULSEN, O.L., GERMS, G.J.B., WIT, M.J., MACHACHA, T. \& MULLER, R.M. 1995. Tectonic controls of basin evolution in southwestern Gondwana. In: Tankard, A.J., Suárez R.S. \& Welsink, H.J. (eds.), Petroleum basins of South America, AAPG Memoir, 62, 5-52.

TARD, F., MASSE, P., WALGENWITZ, F. \& GRUNEISEN, P. 1991. The volcanic passive margin in the vicinity of Aden, Yemen. Bulletin des Centres de Recherches Exploration-Production Elf-Aquitaine, 15, 1-9.

TAVIANI, M. 1998. Axial sedimentation of the Red Sea transitional region $\left(22^{\circ}-25^{\circ} \mathrm{N}\right)$ : pelagic, gravity flow and sapropel deposition during the late Quaternary. . In: Purser, B.H. \& Bosence, D.W.J. (eds.), Sedimentation and tectonics of rift basins: Red Sea - Gulf of Aden. Chapman \& Hall, London, p. 467-478.

TIBERI, C., LEROY, S., D'ACREMONT, E., BELLAHSEN, N., EBINGER, C., AL-LAZKI, A. \& POINTU, A. 2007. Crustal geometry of the northeastern Gulf of Aden passive margin: localization of the deformation inferred from receiver function analysis. Geophysical Journal International, 168, 12471260.

UNTERNEHR, P., PÉRON-PINVIDIC, G., MANATSCHAL, G. \& SUTRA, E. 2010. Hyper-extended crust in the South Atlantic: in search of a model. Petroleum Geoscience, 16, 207-215.

VOGGENREITER, W., HOTZL, H. \& MECHIE, J. 1988. Low-angle detachment origin for the development of the Red Sea? Tectonics, 150, 51-75.

VOGGENREITER, W. \& HOTZL, H. 1989. Kinematic evolution of the southwestern Arabian continental Margin: implications for the origin of the Red Sea. Journal of African Earth Sciences, 8, 541-564.

WATREMEZ, L., LEROY, S., ROUZO, S., D'ACREMONT, E., UNTERNEHR, P., EBINGER, C., LUCAZEAU, F. \& AL-LAZKI, A. 2010. The crustal structure of the north-eastern Gulf of Aden continental margin: insights from wide-angle seismic data. Geophysical Journal International, 184, 575594.

WEGENER, A. 1912. "Die entstehung der kontinente" (in German). International Journal of Earth Sciences, 3, 276-292, doi:10.1007/BF02202896.

WELSINK, H.J., DWYER, J.D., \& KNIGHT, R.J. 1990. Tectono-Stratigraphy of Passive Margin off Nova Scotia. In: Tankard, A.J. \& Balkwill, J.R. (eds) In: Extensional Tectonics and Stratigraphy of the North Atlantic Margins. American Association of Petroleum Geologists Memoir 31, 215-231.

WERNICKE, B. 1985. Uniform-sense normal simple-shear of the continental lithosphere. Canadian Journal of Earth Sciences, 22,108-125.

WHITE, R.S. \& MCKENZIE, D.P. 1989. Magmatism at rift zones: the generation of volcanic continental margins and flood basalts. Journal of Geophysical Research, 94, 7685-7730.

WHITE, R.S., MCKENZIE, D. \& O'NIONS, R.K. 1992. Oceanic crustal thickness from seismic measurements and Rare Earth Element inversions. Journal of Geophysical Research, 97, B13, $19,683-19,715$. 
WITHJACK, M.O. \& SCHLISCHE, R.W. 2005. A review of tectonic events on the passive margin of Eastern North America. In: POST, P.J., ROSEN, N.C., OLSON, D.L., PALMES, S.L., LYONS, K.T. \& NEWTON, G.B. (eds) Petroleum Systems of Divergent Continental Margin Basins. GCSSEPM 25th Annual Bob F. Perkins Research Conference, Houston, Texas, 203-235.

WHITMARSH, R.B., MINSHULL, T.A., RUSSEL, S.M., DEAN, S.M., LOUDEN, K.E. \& CHIAN, D., 2001. The role of syn-rift magmatism in the rift-to-drift evolution of the West lberia continental margin: geophysical observations. In: Wilson, R.C.L., Whitmarsh, R.B., Taylor, B. \& Froitzheim, N., NonVolcanic Rifting of Continental Margins: A Comparison of Evidence from Land and Sea. Geological Society, London, Special Publications, 187, 107-124.

WHITMARSH, R.B., WHITE, R.S., HORSEFIELD, S.J., SIBUET, J.-C., RECQ, M. \& LOUVEL, V. 1996. The ocean-continent boundary off the western continental margin of Iberia: crustal structure west of Galicia Bank. Journal of Geophysical Research, 101, B12, 28, 291-28, 314.

WILSON, R.C.L., HISCOTT, R.N., WILLIS, M.G., AND GRADSTEIN, F.M., 1989. The Lusitanian Basin of west-central Portugal: Mesozoic and Tertiary tectonic, stratigraphic, and subsidence history. In: Tankard, A.J. \& Balkwill, H.R. (eds.), Extensional tectonics and stratigraphy of the North Atlantic margins AAPG Memoir, 46, 341 - 361.

WOLFENDEN, E., EBINGER, C., YIRGUB, G., DEINOC, A. \& AYALEW, D. 2004. Evolution of the northern Main Ethiopian rift: birth of a triple junction. Earth and Planetary Science Letters, 224, 213228.

ZALÁN, P.V., SEVERINO, M.C.G., RIGOTI, C.A., MAGNAVITA, L.P., DE OLIVEIRA, J.A.B. \& VIANNA, A.R. 2011. An Entirely New 3D-View of the Crustal and Mantle Structure of a South Atlantic Passive Margin: Santos, Campos and Espírito Santo Basins, Brazil. Extended Abstract, American Association of Petroleum Geologists Annual Convention \& Exhibition, Houston, Texas, April 2011. http://www.searchanddiscovery.com/abstracts/html/2011/annual/abstracts/Zalan.html 


\section{Figure Captions}

1. Satellite image showing the North and South Atlantic Oceans with the present-day spreading center separating Mesozoic rifted margins in different stages of evolution. The Red Sea and Gulf of Aden are related to divergent motions between Africa and Arabia that started in the Paleogene, and may be considered as modern analogues of the Mesozoic breakup that formed the Atlantic continental margins. Labels and stars indicate regions and features discussed in the text.

2. Comparison between schematic geological transects along the continental margins offshore Canada (Scotian Basin) and Brazil (Campos Basin).

3. Tectono-stratigraphic columns comparing the South Atlantic and North Atlantic margins development with pre-rift, syn-rift, and transitional evaporitic sequences formed previous to continental breakup. Subsequently, marine carbonatic to siliciclastic sequences were formed as the plated drifted apart. .

4. Regional geological map of the Red Sea and Gulf of Aden on satellite image of the African-Arabian plates.

5. Regional tectonic map of the Somalian and Arabian plates, characterized by nascent divergent margins, and the convergent boundary between Arabia and Iran. The Red Sea and Gulf of Aden are characterized by spreading centers formed in the Neogene. The Sheba Ridge separates the Oman rift basins from the conjugate margin rifts in northern Somalia and Socotra. The Aden Ridge is characterized by an oceanic propagator that is advancing towards the Afar region. Transform fault zones separate segments of the spreading center (example, Owen Transform Fault). Active plate boundaries (both divergent and convergent) are marked by earthquakes. The map shows only the earthquakes with magnitude greater than 5, registered from 1960 to 2011 . The location of the seismic profile in the Red Sea spreading center (SS-1) and the refraction profiles in the western margin of the Red Sea (S-1 and P-1) are indicated as yellow lines.

6. Tectono-stratigraphic columns of the Gulf of Suez-Red Sea-western Gulf of Aden comparing the development of the rifted margins.

7. Schematic reconstructions of the Red Sea and Gulf of Aden showing the evaporite deposition in Neogene times (10-5 Ma) and the development of an active spreading center in the central Red Sea (3-0 Ma). The Aden Ridge between the Somali Block and the Arabian Plate is advancing towards the Afar region.

8. Comparison of salt tectonics extensional styles in the Red Sea (Gulf of Suez) and in the Santos Basin, offshore Brazil. The development of major salt diapirs occurs very early in the geological development of these basins. In the South Atlantic, halokinesis has continued for more than $100 \mathrm{Ma}$, resulting in very large salt diapirs in the conjugate continental margins (Brazil - Angola), with massive salt walls and allochthonous salt tongues near the transition from the continent to oceanic crust. In the Gulf of Suez 
example shown here, the salt wall is located in the deeper part of the basin, with thin salt towards the platforms.

9. Comparison of salt tectonics structures in the Red Sea (Amber borehole, offshore Ethiopia, which drilled a thick salt wall north of the Dahlac Islands) with equivalent structures in the Santos Basin (Tupi discovery, a supergiant oil field). In the Santos Basin, presalt reservoirs are sealed by stratified evaporites that may reach more than $2000 \mathrm{~m}$ in thickness.

10. Schematic interpretation of the Red Sea refraction transect (P1) from the onshore region towards the transitional and oceanic crust, which is characterized by magnetic anomalies M2 to M4. Location of profile is shown on Figure 5.

11. Conceptual tectonic model for breakup in the Red Sea between Sudan and Saudi Arabia. Incipient spreading is observed in the axial trough, separating two Late Miocene salt basins (Mohriak et al. 2010)

12. Comparison of seismic profiles in the present-day spreading ridge in the central Red Sea (see location on Fig. 5) with an embryonic spreading center in the southern Santos Basin, interpreted as an oceanic propagator aborted before the final breakup. (A) In the Red Sea, the top of the evaporites is characterized by an undulating topography indicative of early halokinesis, resulting in anticlinal and synclinal structures and minibasins. (B) The Abimael Ridge propagated from the Pelotas towards the Santos Basin in the Early Cretaceous and was aborted in the early Albian, but separated salt basins by incipient spreading in the axial trough, which has been preserved in the Brazilian side of the conjugate margins.

13. (A) Topo-bathymetric map of the Southeastern Brazilian region with location of earthquake epicenters and main tectonic elements along the continental margin. Location of the seismic profile is indicated by the yellow line. AR: Abimael Ridge; AS: Almirante Saldanha Seamount; AVC: Abrolhos Volcanic Complex; CBFZ: Cabo Frio Fault Zone; FFZ: Florianópolis Fracture Zone; LC Leplac: Limit of crusts from Leplac project; LV: Limit of volcanic basement; PAL: pre-Aptian limit of the continental margin basins; RGFZ: Rio Grande Fracture Zone; RGR: Rio Grande Rise; SCL: Southern Cross (Cruzeiro do Sul) Lineament; SEH: Southeast Santos Basin High; VT: Vitória-Trindade Lineament;

(B) Separation of the Late Aptian salt basins by an Incipient volcanic spreading center in the southern Santos Basin. Alternative interpretations suggest a peridotite ridge or belt of exhumed mantle; however, the feature is characterized by a negative magnetic anomaly and by a positive gravity anomaly.

14. In the southern Santos Basin/northern Pelotas basin the propagator is associated with volcanic rocks in the proto-oceanic crust (as indicated by wedges of seaward-dipping reflectors) and the mantle is not exhumed, indicating that breakup resulted in massive magmatism probably influenced by a mantle plume. 
15. Simplified geological map of the Gulf of Aden - Red Sea region, with main structural elements. Seismic profiles indicate the occurrence of volcanoes near the continentocean transition in the Gulf of Aden. The Aden ridge separates conjugate divergent margins and is presently propagating towards the west (Gulf of Tadjura, in the Afar region).

16. Topobathymetric map of the Gulf of Aden region with main tectonic elements and location of regional profiles in the south Oman and north Somalia conjugate margins. The Sheba Ridge is offset by major transform fault zones and is marked by increased magmatic activity in Pleistocene to Recent times, particularly along the segment between the Socotra Fracture Zone and the Alula-Fartak Fracture Zone. The Aden Ridge is propagating towards the Afar region, and the conjugate margins west of the Shukra El Sheik Fracture Zone are clearly volcanic. Regional seismic transects near the Socotra transform fault zones are characterized by Neogene rift basins in the proximal part. The western transect corresponds to a complete seismic profile across an incipient divergent margin, including ES-26 in the south (offshore Socotra) and ES-12 in the north (offshore Oman). The eastern transect, near the Socotra Island, includes the profiles ESS-20 and ENC-18, and is shown in this work as a geological cross-section (Fig. 20).

17. Topobathymetric map of the Afar region where Neogene volcanic rocks are associated with a mantle plume and extensional tectonics forming depressions adjacent to the Red Sea and Gulf of Aden. The Erta Ale volcano is characterized by bluish colors and is located west of the Danakil horst, northwest of the Gulf of Tadjura, the western tip of the Aden propagator. The Asal Lake (light blue color) is located immediately to the west of the Gulf of Tadjura. Several volcanoes and lava flow deposits occur onshore, west of the Strait of Bab-el-Mandeb, a narrow strait linking the Red Sea and the Gulf of Aden. The conjugate margins in the Arabian and Somalian plate, near the Afar region, are characterized by seaward-dipping volcanic wedges.

18. Seismic profile in the Gulf of Aden northern margin offshore Oman (ENC-34), extending from the distal part of the Ashawq - Salalah Graben through the ocean-continent transition and oceanic crust. The OCT is marked by a volcanic feature that outcrops at sea-bottom., and a large heat flow anomaly is also observed in this region. The oceanic crust is characterized by magnetic anomalies indicative of organized spreading in the Miocene. Anomaly A5d (about 17.6 Ma) is located near the western flank of the volcano. Younger magnetic anomalies are observed towards the present-day spreading center (Sheba Ridge), and a large volcanic province is observed near the present-day ridge crest, indicating excessive magmatism at the plate boundary.

19. Schematic line interpretation of the seismic profile ENC-34 (see location on Figure 16) in the northern Gulf of Aden, crossing the Ashawk - Salalah Graben and extending through the ocean-continent transition (which is marked by rotated blocks and a sag basin). A volcanic build-up overlies the OCT volcanics and sediments in the transition from continental to oceanic crust. A magmatically accreted igneous crust (with possible 
underplating) is interpreted near the continent-ocean transition, but there is an alternative possibility of mantle exhumation near the continent-ocean boundary. The oceanic crust is characterized by magnetic anomalies indicative of organized spreading in the Miocene (anomalies A6 to A5, 20 to $16 \mathrm{Ma}$ ). Increased magmatism is indicated towards the present-day Sheba Ridge, which separates the Somalian and the Arabian plates.

20. (A) Schematic reconstruction of the Socotra-Oman pre-breakup rifted basins in the Gulf of Aden, corresponding to the eastern transect shown on Fig. 16, located just west of the Socotra Island. It shows the complementary asymmetry of the opposing margins and the distribution of the Neogene rifts. The location of the breakup where the oceanic spreading center initially formed is offset towards Socotra, resulting in a narrow margin. A detachment is interpreted to occur at shallower depths in the lower plate (Socotra) and penetrate deeper into the crust towards the upper plate, which is characterized by the Southern Oman margin rift basins.

(B) After breakup, organized spreading formed an oceanic crust characterized by magnetic anomalies that date back to anomaly $5 d$ (about 17.6 Ma). The Sheba Ridge is the present-day spreading center, marked by a bathymetric low and large magnetic anomalies.

21. Reconstruction map of the Gulf of Aden and the Neogene rifts between the Arabian and Somalian plates just before the continental breakup and formation of oceanic crust (about $18 \mathrm{Ma}$ ). Large grabens onshore Yemen and Somalia (example, Balhaf and Berbera, Masilah and Darror) were formed during pre-Cretaceous extensional events and correspond to inherited structures with some reactivation in the Neogene. The reconstruction shown on Figure 20 is located near the Socotra-Hadbeen Fracture Zone (SHFZ), near the Socotra Island.

22. Top: reconstruction map of the South Atlantic just before continental breakup (112 Ma), with sag basins developed offshore Kwanza and in the Santos Basin;

Bottom: Geoseismic transects across approximate conjugate margins offshore Brazil (B) and West Africa (A). The present-day spreading center (Mid-Atlantic Ridge) is located more than $2000 \mathrm{~km}$ beyond the continent-ocean boundary in both margins.

23. Geoseismic transect west of Socotra (location on Fig. 16) across the conjugate margins offshore Somalia (SSW) and South Oman (NNE). Organized spreading is indicated by magnetic anomalies from the plataform (anomaly $5 \mathrm{~d}$, about $17.6 \mathrm{Ma}$ ) towards the present-day spreading center (Sheba Ridge), which is located $170 \mathrm{~km}$ from the continent-ocean boundary in the Somalian margin, and about $270 \mathrm{~km}$ from the continentocean boundary in the South Oman margin. Volcanic features occur adjacent to the spreading center, which is a deep trough with a thin veneer of recent sediments.

24. Continental breakup model with embryonic spreading in volcanic and non-volcanic margins, subdivided into tectonic domains $A-E$. The transect $X-Y$ might correspond to a cross section in the Red Sea margins, still in the early stages of separation by an active spreading center. The South Atlantic divergent margins correspond to a more advanced 
stage of plate divergence, where the oceanic crust formed about 110 Ma ago. Volcanic features and igneous intrusions are located near the continental-oceanic crust transition in the South Atlantic, whereas in magma-poor margins the COT is characterized by peridotite ridges.

25. Tectonic model for the Espírito Santo-Kwanza conjugate margins during breakup and early post-breakup phases, corresponding to the X-Y profile on Fig. 24. It assumes unthinned crust $(A)$ landwards of the rift basins, where only post-breakup sediments onlap pre-rift rocks and basement. The thinned crust is characterized by a syn-rift basin with siliciclastic and carbonates predominant in the proximal part (B), and increased influence of volcanic rocks in the distal margin $(C)$, which is affected by younger faults. A thick sag basin, underlain by evaporites, marks the final stages of the rifting and breakup. The drift-phase sediments across the conjugate margins are separated by an igneous crust (D) with a spreading center (E). Magma injection and dikes affected the continental crust in the continent-ocean transition, resulting in accretion of magmatic crust. A high-velocity/high density underplated lower crust is marked by a strong $M$ reflector near the transition from crust to mantle. 
Tables:

Table I:

North Atlantic (Newfoundland - Iberia) vs. South Atlantic (Campos - Kwanza) conjugate divergent margins

Table II:

South Atlantic (Campos - Kwanza) vs. Red Sea / Gulf of Aden conjugate divergent margins 


\section{Table I:}

\section{North Atlantic (Newfoundland - Iberia) vs. South Atlantic (Campos - Kwanza) conjugate divergent margins}

\begin{tabular}{l|}
\hline Proximal margin with widespread volcanism dated \\
around 200-201 Ma. (Central Atlantic Magmatic Province \\
- CAMP), distal margin with sparse to negligible \\
volcanism in the rifted continental crust \\
(5) \\
\hline Proximal margin with thick syn-rift sequences covered by \\
post-rift sediments; distal margin with thin syn-rift \\
sequences in highly tilted blocks, which have been \\
sediment-starved since the breakup. \\
(7)
\end{tabular}

Peridotite ridges occur in ultradeep waters and are overlain by pelagic sediments in the abyssal plain. (4)

Proximal margin with inner rift basins showing small amounts of salt, distal margin and outer basins with no salt.

(6)
Proximal margin with widespread volcanism dated around 133-135 Ma. (Paraná - Etendeka LIP), distal margin with abundant volcanism in the rifted continental crust, local presence of SDRs.

(10)

Proximal margin with thick syn-rift sequences covered by post-rift sediments; distal margin with thick sag basin that was not affected by normal faults during the late rift phase; outermost salt province highly affected by faults and volcanism

(11)

Outermost highs show indications of volcanic origin and are associated with shallow-water pre-salt sediments. (11)

Proximal margin with inner rift basins showing small amounts of salt, distal margin and outer basins with extremely thick autochthonous and allochthonous salt layers.

(11)

Evaporite deposition dated around 112-115 Ma

Evaporite deposition dated around 195-208 Ma (6)

Rifting in the proximal margin did not evolve into oceanic crust, rifting in the distal margin happened tens of million years after the proximal rifting event, with breakup around $112 \mathrm{Ma}$

(7)

Very long and complex period of continental rifting (230-

145), mantle exhumation until breakup (145-112) (8)

Volcanoes are uncommon in continental crust or in the ocean-continent transition.

(3)

Basement ridges of hyper-extended continental crust occur in the ocean-continent transition.

(2) (10)

Rifting in the proximal margin did not evolve into oceanic crust, rifting in the distal margin happened a few million years after the proximal rifting event, with breakup around 112-110 Ma.

$(10)$

Very short period of continental rifting until breakup (130$115 \mathrm{Ma})$

(10)

Volcanoes are common in continental crust and in the continent-ocean transition.

(12)

Volcanic highs occur in the ocean-continent transition, with considerable thickness of continental and igneous crust.

(11)

Non-magnetic to poorly magnetic peridotite ridges observed in the continent-ocean transition.

(1)

Outer high with mass deficiency due to serpentinization (1)

Highly magnetic igneous intrusions are observed in the continent-ocean transition.

(11)

Outer highs generally marked by high gravity anomaly, locally the gravity anomaly may be reduced due to increased mantle temperature or density anomalies. (11)

Shallow detachment zones (S reflector) above serpentinized mantle.

(2)

Intracrustal detachment zones occur above the crust/mantle transition; underplating is often indicated by lower crust layered reflectors

(9)

Low heat flow in the distal margin that did not produce significant melts in the outer basin.

(4)

Asymmetric rifts with simple shear detachments along the conjugate margins.

(1)

Very high heat flow in the distal margin producing melts and hydrothermal events

(11)

Symmetric rifts with pure shear extension, local asymmetry may be related to ridge jumps or crustal heterogeneities.

(11)

Key-references: (1) Boillot et al., 1980; (2) Sibuet 1992; (3) Boillot et al. 1995; (4) Whitmarsh et al. 1996; (5) McHone et al. 2005; (6) Alves et al. 2006; (7) Tucholke et al. 2007; (8) Péron-Pinvidic et al. 2007; (9) Chang et al. 1992; (10) Mohriak 2003; (11) Mohriak et al. 2008; (12) Mohriak et al. 2010. 
Table II:

South Atlantic (Campos - Kwanza) vs. Red Sea / Gulf of Aden conjugate divergent margins

\begin{tabular}{|c|c|c|}
\hline $\begin{array}{l}\text { Tectonic } \\
\text { Phases }\end{array}$ & South Atlantic & Red Sea / Gulf of Aden \\
\hline $\begin{array}{l}\text { Early Development } \\
\text { Geodynamics }\end{array}$ & $\begin{array}{l}\text { Subduction in the Pacific and in the } \\
\text { South African margins } \\
\text { (3) }\end{array}$ & $\begin{array}{l}\text { Subduction in the Persian Gulf } \\
\text { (1) }\end{array}$ \\
\hline Pre-rift magmatism & $\begin{array}{l}\text { Tristan da Cunha Plume around } \\
\text { 135-133 } \mathrm{Ma} \\
\text { (5) }\end{array}$ & $\begin{array}{l}\text { Afar Plume around } 45-20 \mathrm{Ma} . \\
\text { (3) Main event at } 30 \mathrm{Ma}(9)\end{array}$ \\
\hline Syn-rift phase & $\begin{array}{l}\text { 130-115 Ma. in SE Brazil } \\
\text { (5) }\end{array}$ & $\begin{array}{l}\text { 34-18 Ma in the Gulf of Aden (4); } \\
24-16 \mathrm{Ma} \text {. in the Gulf of Suez and } \\
\text { northern Red Sea. } \\
\text { (3) }\end{array}$ \\
\hline Evaporite deposition & $\begin{array}{l}\text { 115-112 Ma. in SE Brazil } \\
\text { (5) }\end{array}$ & $\begin{array}{l}\text { 10-5 Ma. in the Red Sea; Late Tertiary } \\
\text { gypsum layers in the Gulf of Aden } \\
\text { (3) }\end{array}$ \\
\hline Continental Breakup & $\begin{array}{l}\text { around } 130-115 \mathrm{Ma} \text {. in Argentina } \\
\text { and South Africa; } 112-110 \mathrm{Ma} \text {. in } \\
\text { SE Brazil. } \\
\text { (5) }\end{array}$ & $\begin{array}{l}\text { around } 5 \mathrm{Ma} \text {. in the central Red Sea; } \\
\text { around } 18-16 \mathrm{Ma} \text { in the eastern Gulf of } \\
\text { Aden. } \\
(4)\end{array}$ \\
\hline Carbonate Deposition & $\begin{array}{l}112-90 \text { Ma. in SE Brazil } \\
(5)\end{array}$ & $\begin{array}{l}5-0 \text { in the Red Sea (3), } 34-18 \mathrm{Ma} \text { in the } \\
\text { Gulf of Aden (4). }\end{array}$ \\
\hline $\begin{array}{l}\text { Siliciclastic deposition } \\
\text { (drift phase) }\end{array}$ & $\begin{array}{l}90-0 \mathrm{Ma} \\
(5)\end{array}$ & $\begin{array}{l}\text { 5-0 Ma. in the Red Sea (3), 18-0 Ma. in } \\
\text { the Gulf of Aden (4) }\end{array}$ \\
\hline $\begin{array}{l}\text { Post-breakup } \\
\text { magmatism }\end{array}$ & $\begin{array}{l}\text { 84-74 Ma. and } 60-45 \mathrm{Ma} \text {, focused } \\
\text { on Abrolhos and Cabo Frio (SE } \\
\text { Brazilian margin) } \\
\text { (5) }\end{array}$ & $\begin{array}{l}\text { 5-0 Ma. in the Red Sea and Gulf of } \\
\text { Aden, focused on Afar. Post breakup } \\
\text { volcanic layers also occur in W Arabia } \\
\text { and between the Socotra and the Alula- } \\
\text { Fartak fracture zones. } \\
\text { (4) }\end{array}$ \\
\hline Petroleum plays & $\begin{array}{l}\text { Pre-salt, post-salt carbonates, Late } \\
\text { Cretaceous to Late Tertiary } \\
\text { turbidites. } \\
\text { (7) }\end{array}$ & $\begin{array}{l}\text { Pre-salt syn-rift reservoirs in the Gulf of } \\
\text { Suez. Syn-rift and pre-rift targets in the } \\
\text { Yemen and Oman rifts. } \\
\text { (2) }\end{array}$ \\
\hline HC Reserves & $\begin{array}{l}14.2 \times 10^{9} \mathrm{bbl} \text { of oil in Brazil, } 90 \% \\
\text { in the Santos/Campos/ES basins, } \\
13.5 \times 10^{9} \mathrm{bbl} \text { of oil in Angola, most } \\
\text { of it in the Cabinda region. } \\
(8)\end{array}$ & $\begin{array}{l}4.5 \times 10^{9} \mathrm{bbl} \text { of oil in Egypt } \\
2.7 \times 10^{9} \mathrm{bbl} \text { of oil in Yemen } \\
5.5 \times 10^{9} \mathrm{bbl} \text { of oil in Oman } \\
\text { (part of these reserves are in the Gulf of } \\
\text { Suez and in the rifts onshore Yemen } \\
\text { and Oman) } \\
\text { (8) }\end{array}$ \\
\hline
\end{tabular}

Key-references:

(1) Hempton 1987; (2) Beydoun 1989; (3) Bosworth et al. 2005; (4) Leroy et al. 2012; (5) Mohriak 2003;

(6) Macdonald et al. 2003; (7) Fainstein 2008; (8) BP Statistical Review of World Energy 2011 (9)

Hoffman et al 1997. 
Satellite image showing the North and South Atlantic Oceans with the present-day spreading center separating Mesozoic rifted margins in different stages of evolution. The Red Sea and Gulf of Aden are related to divergent motions between Africa and Arabia that started in the Paleogene, and may be considered as modern analogues of the Mesozoic breakup that formed the Atlantic continental margins.

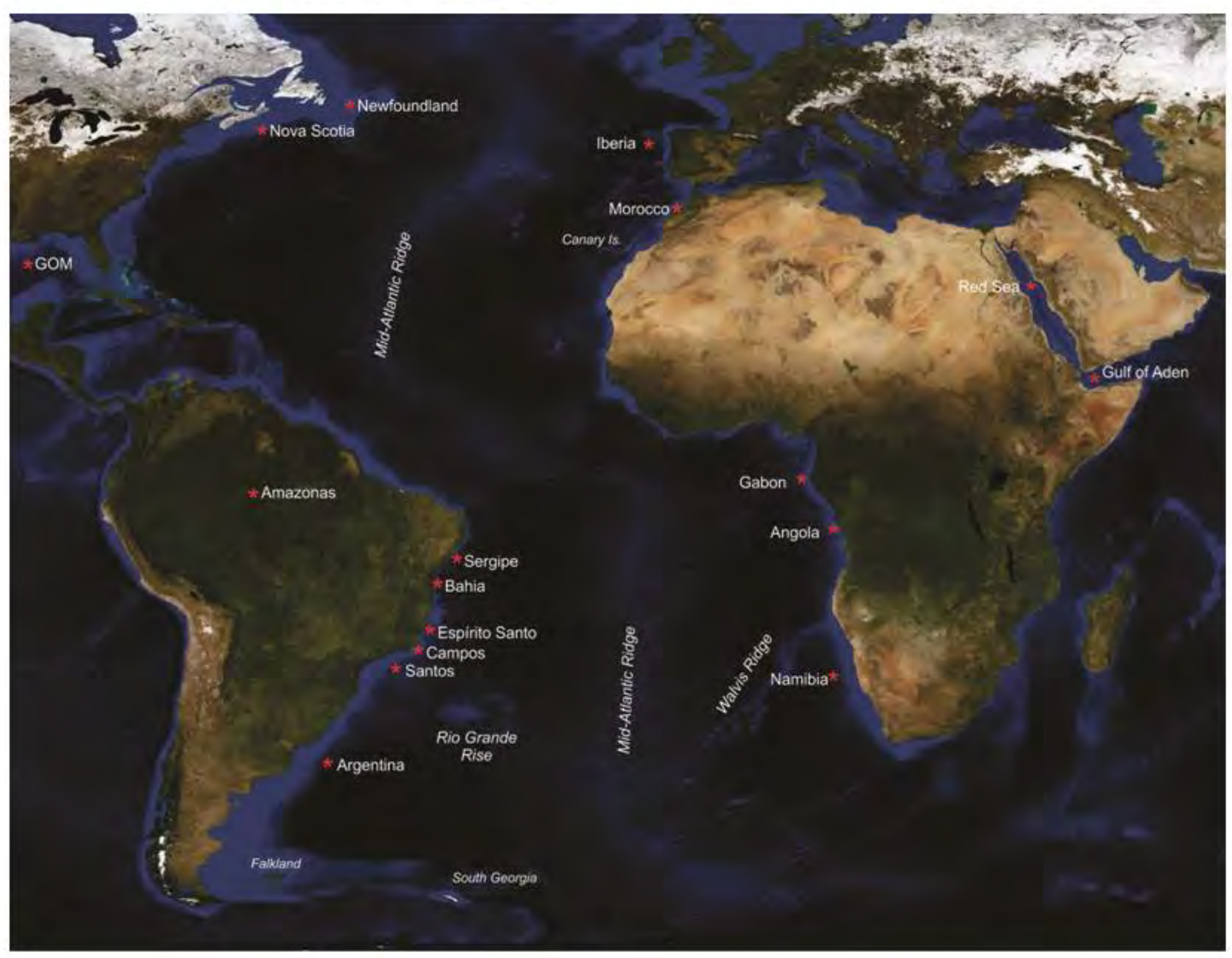




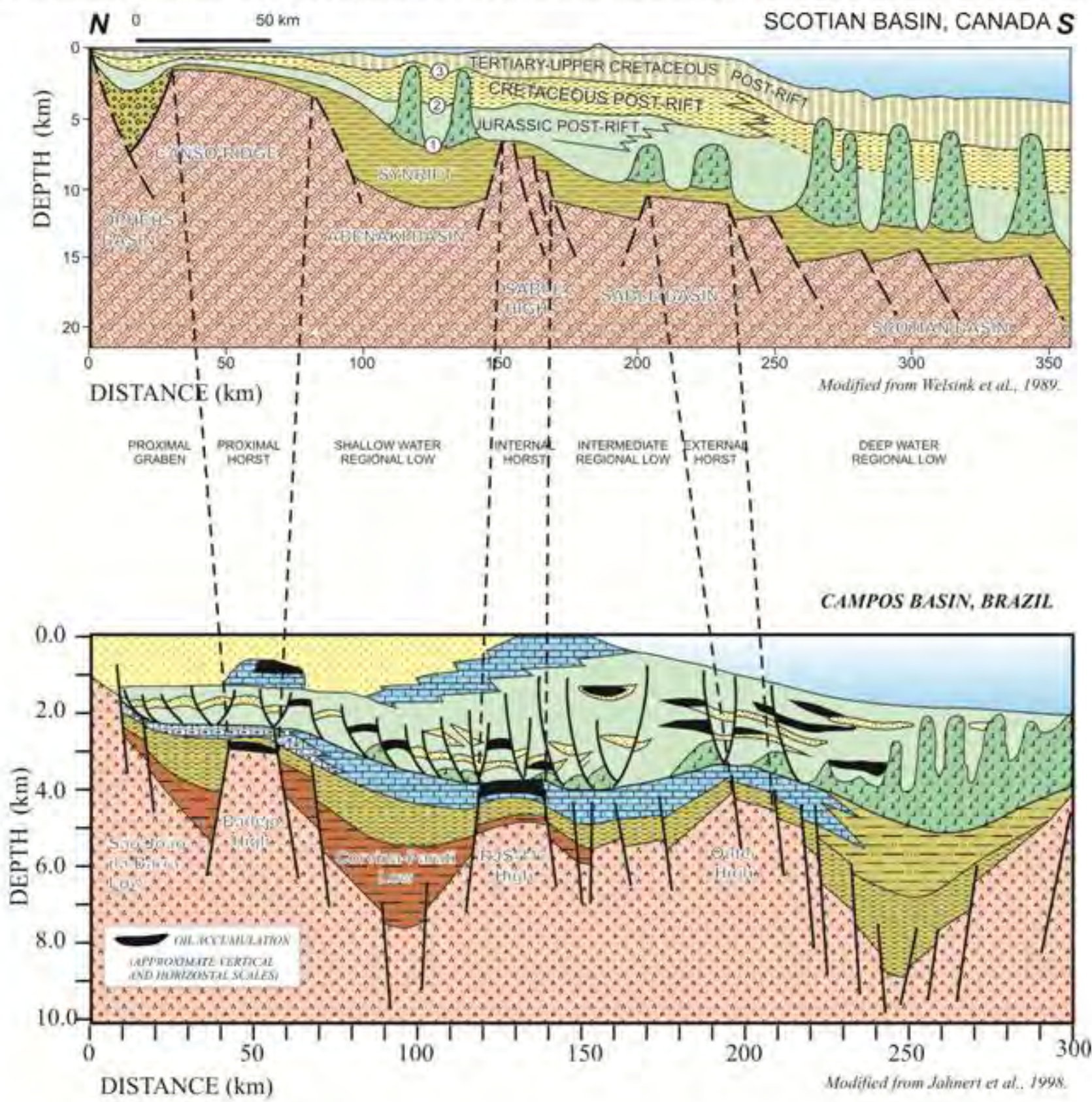




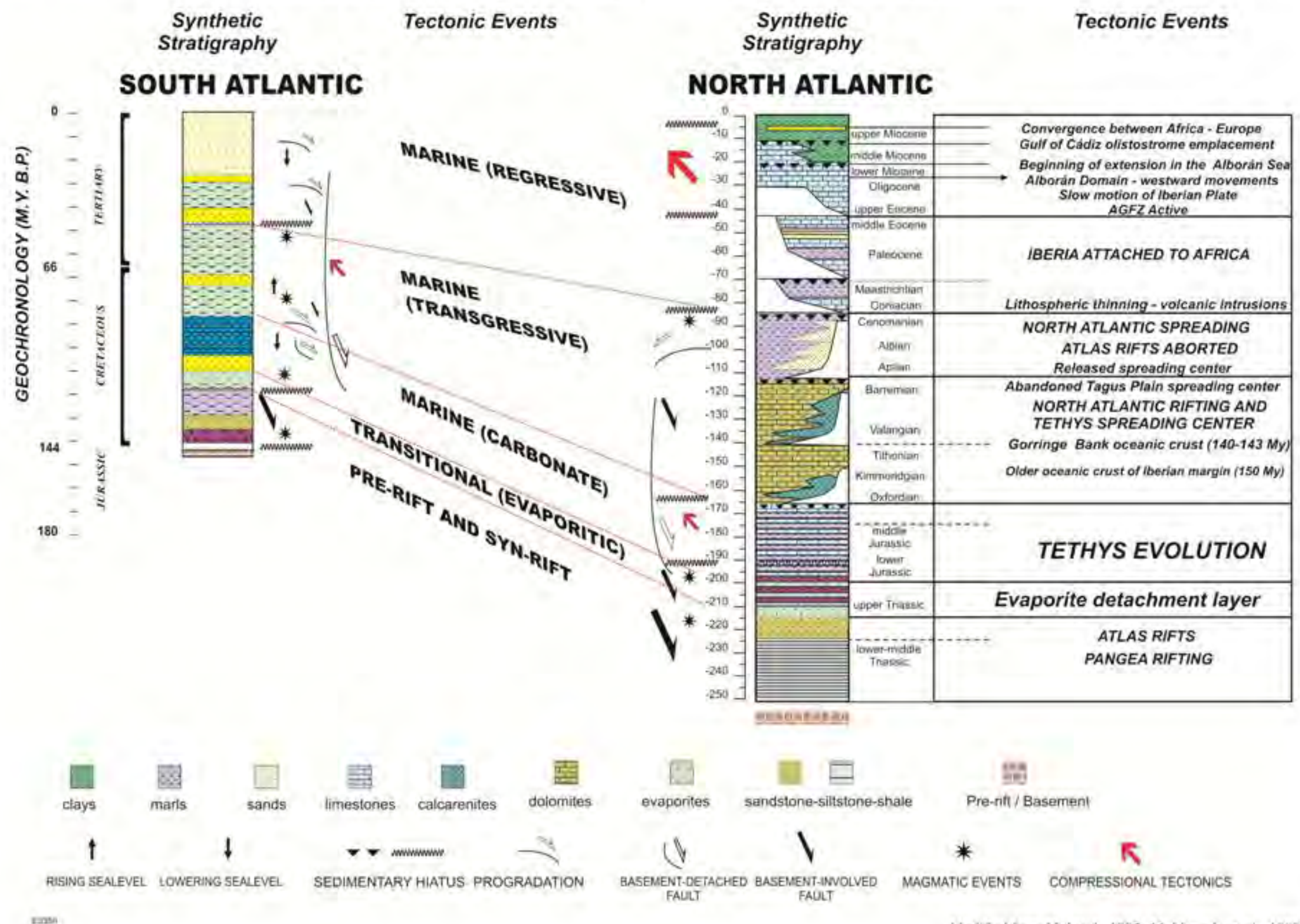


Regional geological map of the Red Sea and Gulf of Aden on satellite image of the African-Arabian plates.

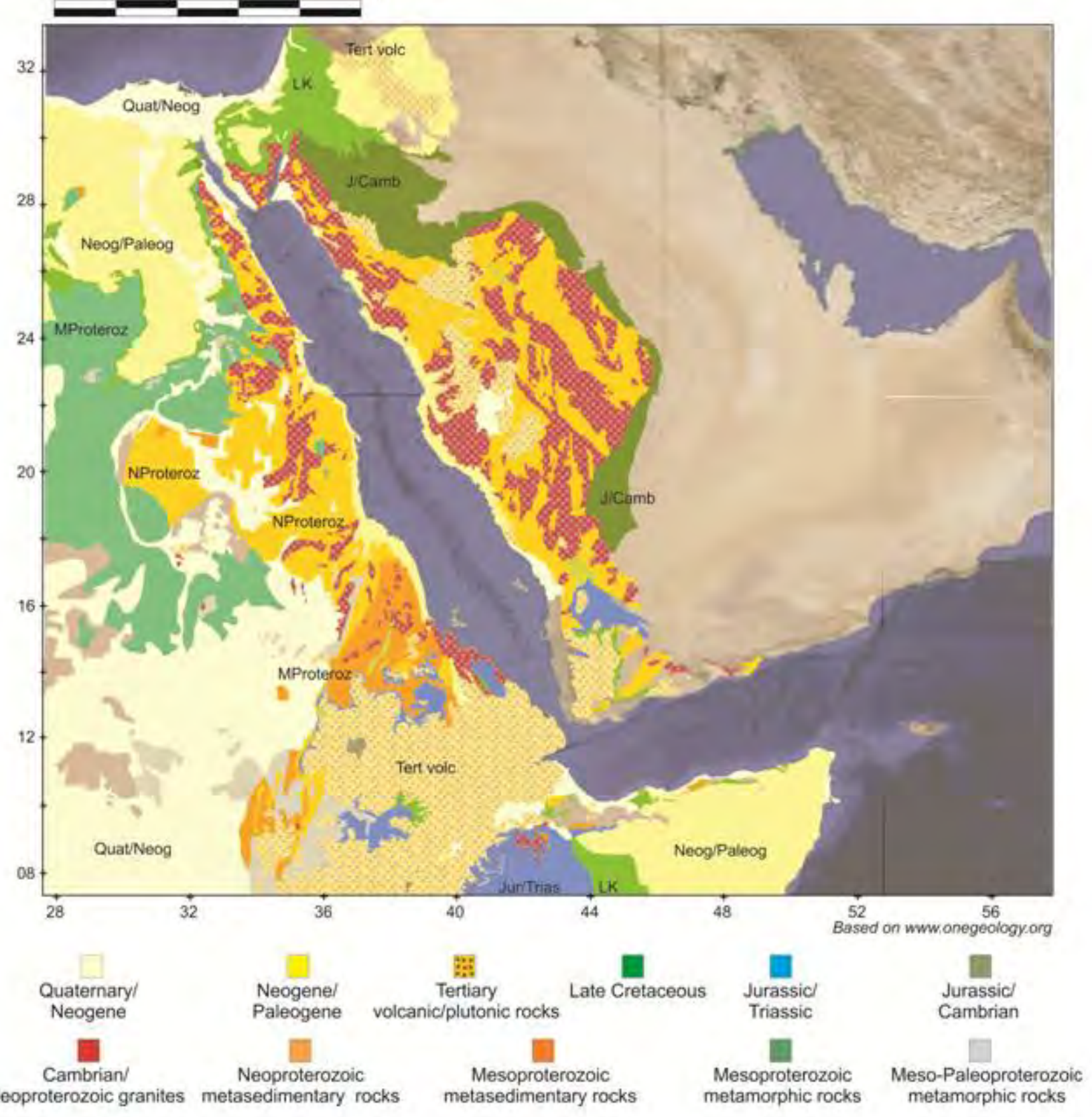


Regional tectonic map of the Somalian and Arabian plates, characterized by nascent divergent margins, and the convergent boundary between Arabia and Iran. The Red Sea and Gulf of Aden are characterizec by spreading centersformed in the Neogene. The Sheba Ridge separatesthe Oman rift basins from the conjugate margin rifts in northern Somalia and Socotra. The Aden Ridge is characterized by an oceanic propagator that is advancing towards the Afar region. Transform faultzones separate segments of the spreading center (example, Owen Transform Fault). Active plate boundaries (both divergent and convergent) are marked by earthquakes. The map shows only the earthquakes with magnitude greater than 5, registered from 1960 to 2011. The location of the seismic profile in the Red Sea spreading center (SS-1) and the refraction profiles in the western margin of the Red Sea (S-1 and P-1) are indicated as yellow lines.

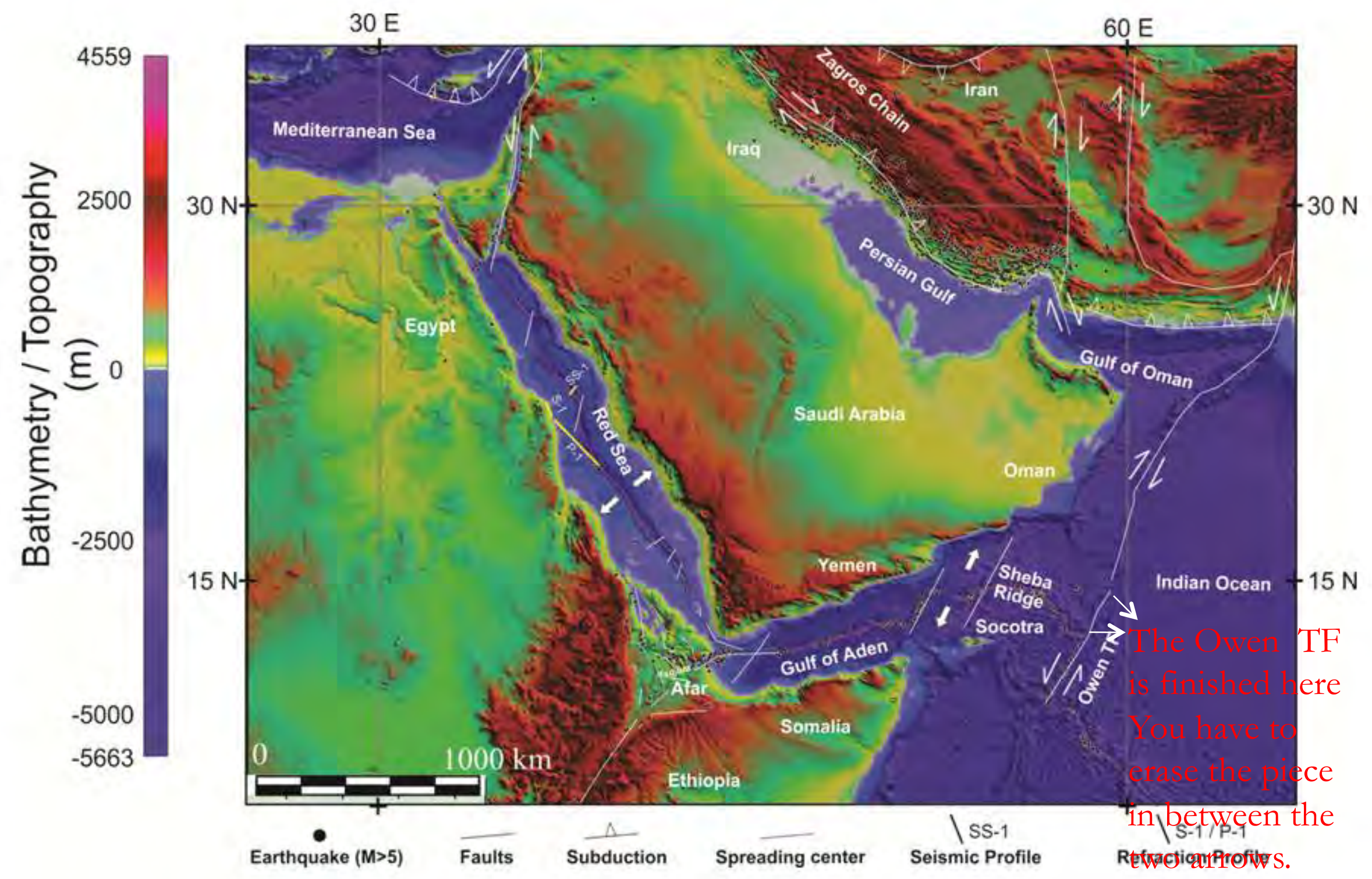


Tectono-stratigraphic columns of the Gulf of Suez - Red Sea - Gulf of Aden comparing the development of the rifted margins.
GULF OF SUEZ
RED SEA
GULF OF ADEN

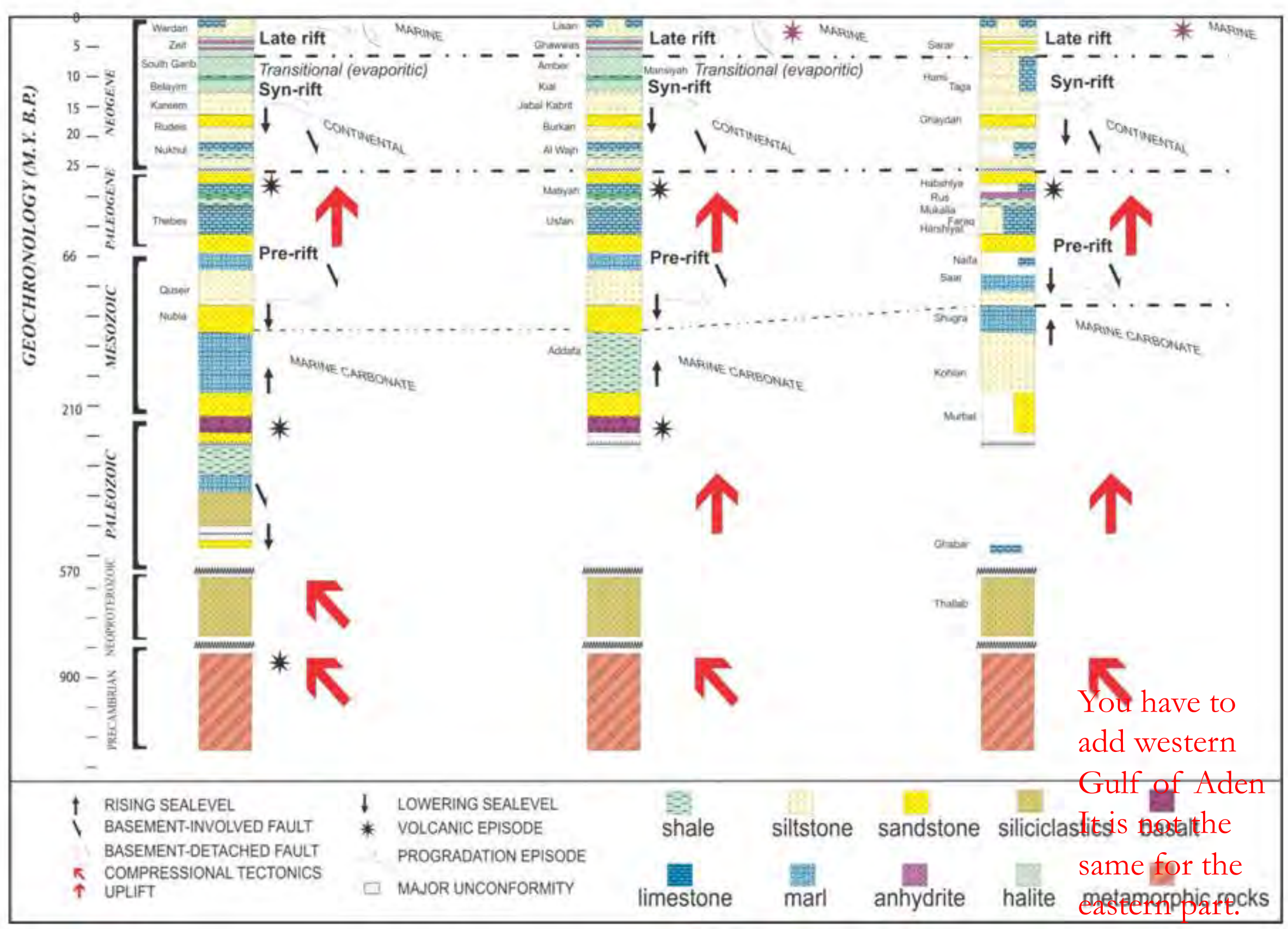




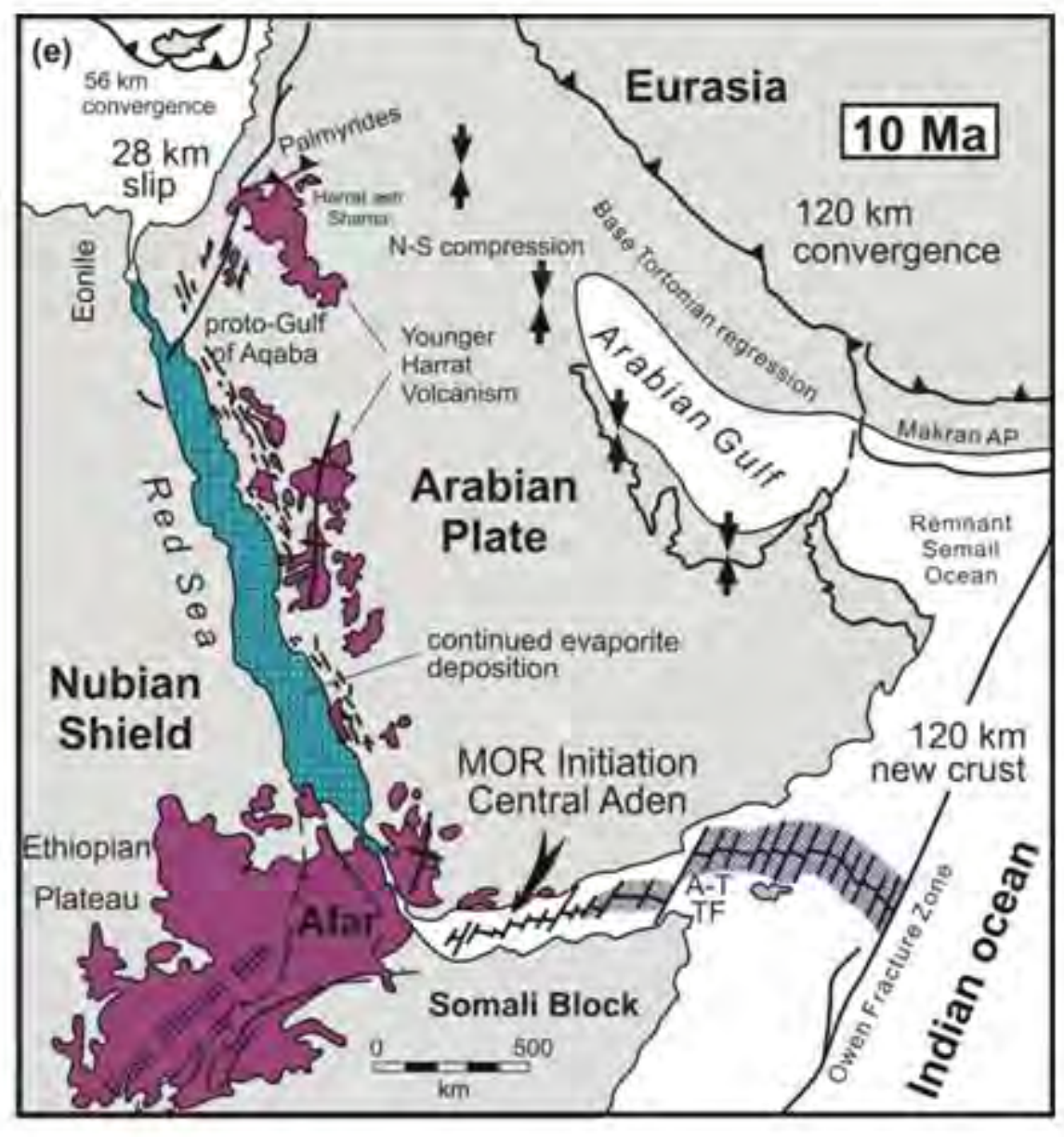

Modified trom Bosworth ot at, 2005 .

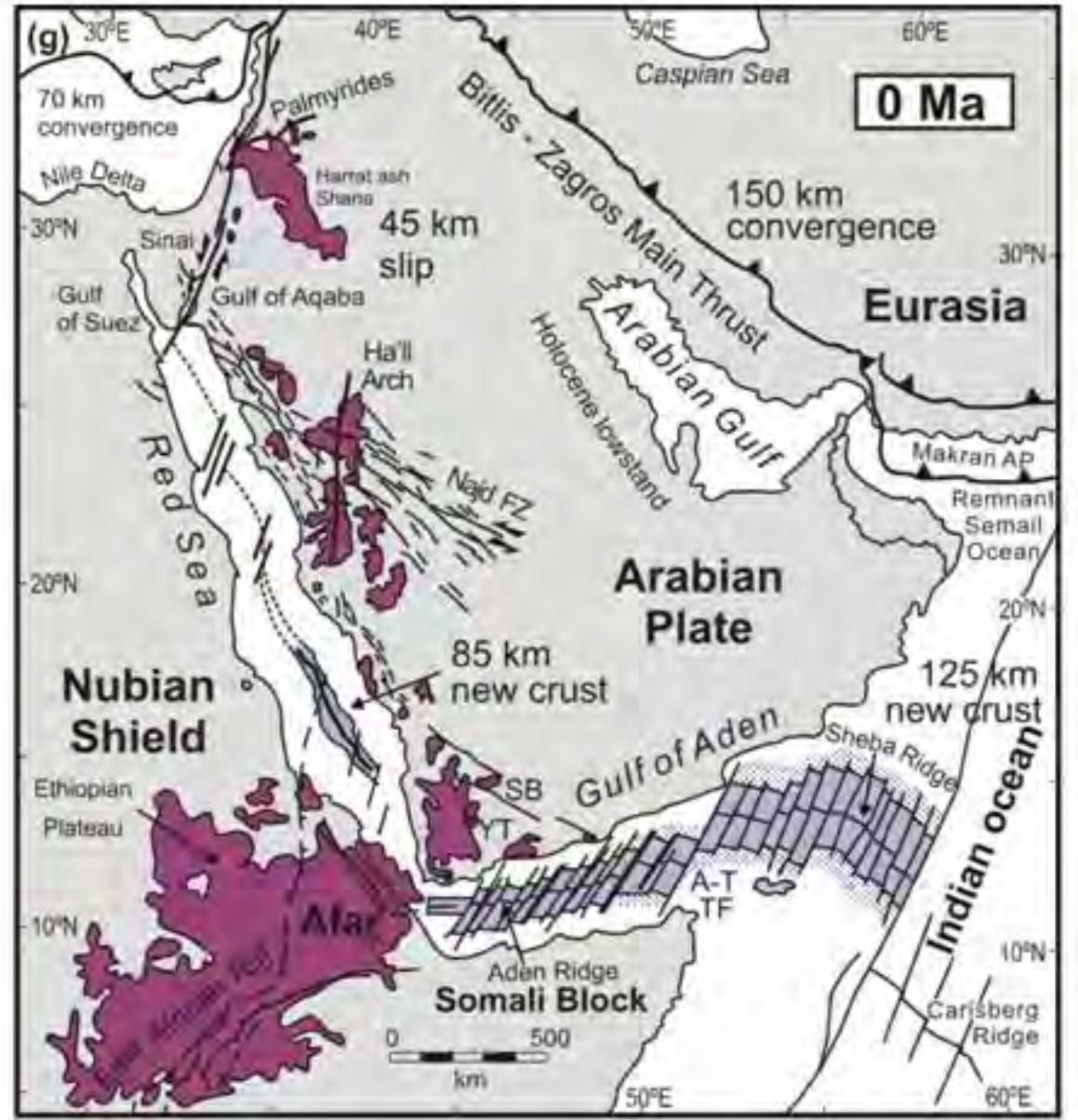

Modified from Bosworth ot al, 2005. 
Comparison of salt tectonics extensional styles in the Red Sea (Gulf of Suez) and in the Santos Basin, offshore Brazil. The development of major salt diapirs occursvery early in the geological development of these basins. In the South Atlantic, halokinesis has continued for more than $100 \mathrm{Ma}$, resulting in very large salt diapirs in the conjugate

continental margins (Brazil-Angola), with massive salt walls and allochthonous salt tonguesnear the transition from the continent to oceanic crust. In the Gulf of Suez example shown here, the saltwall is located in the deeper part of the basin, with thin salt towards the platforms.

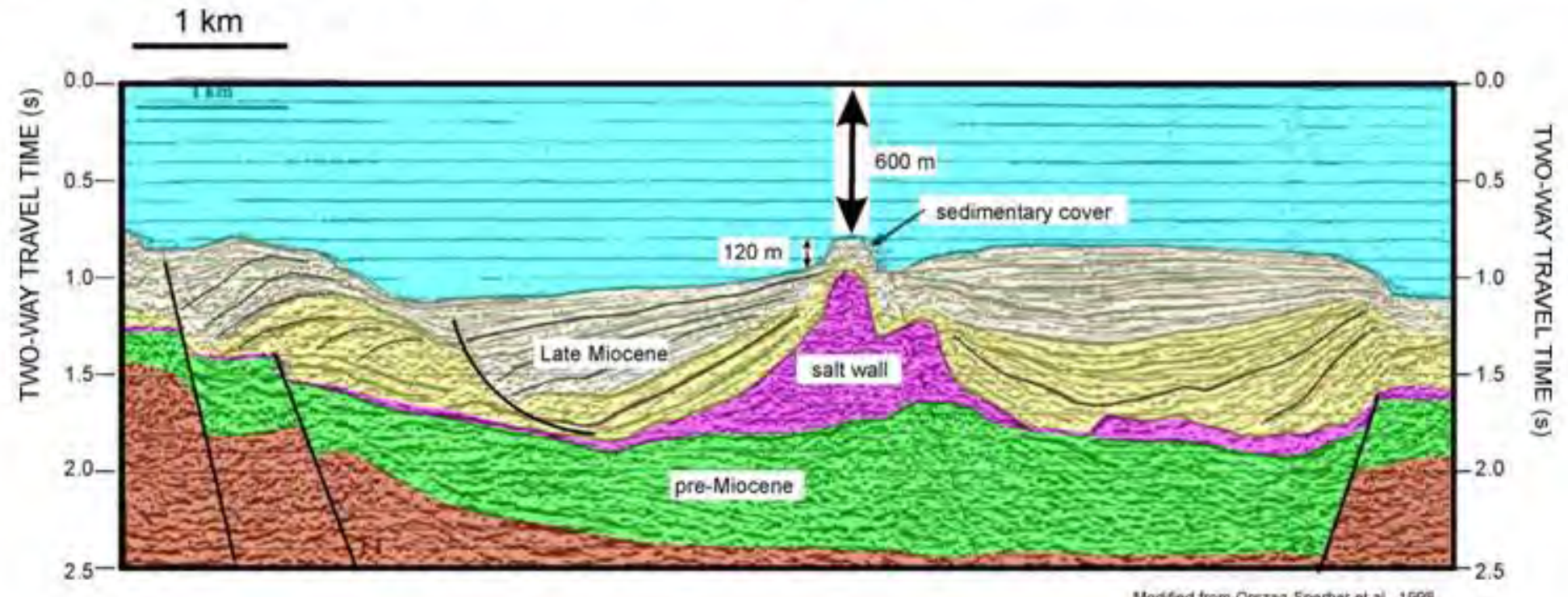

Modfed from Onsag-Sperber et al 1906

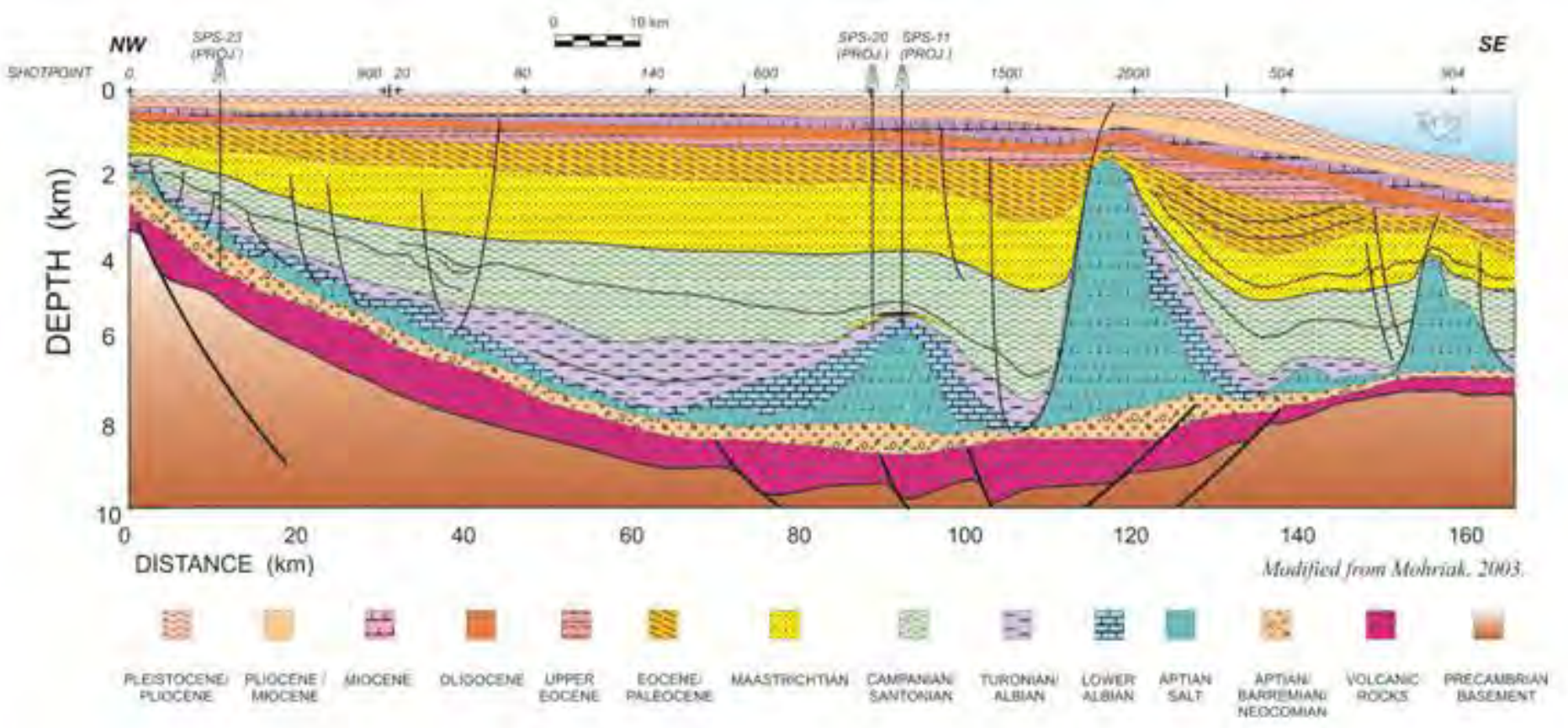




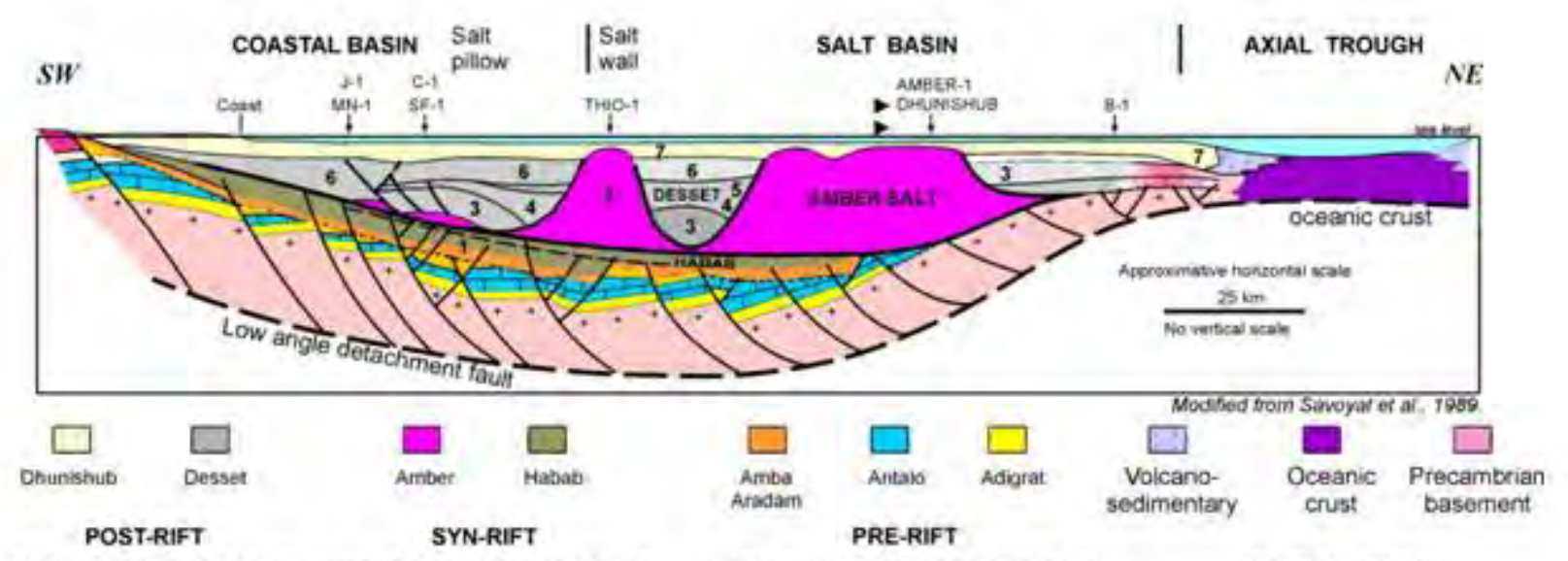

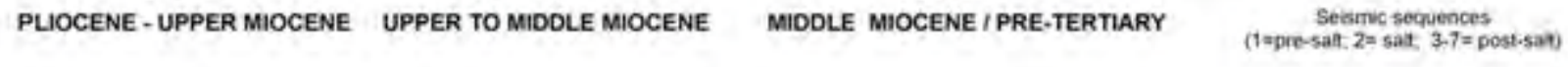

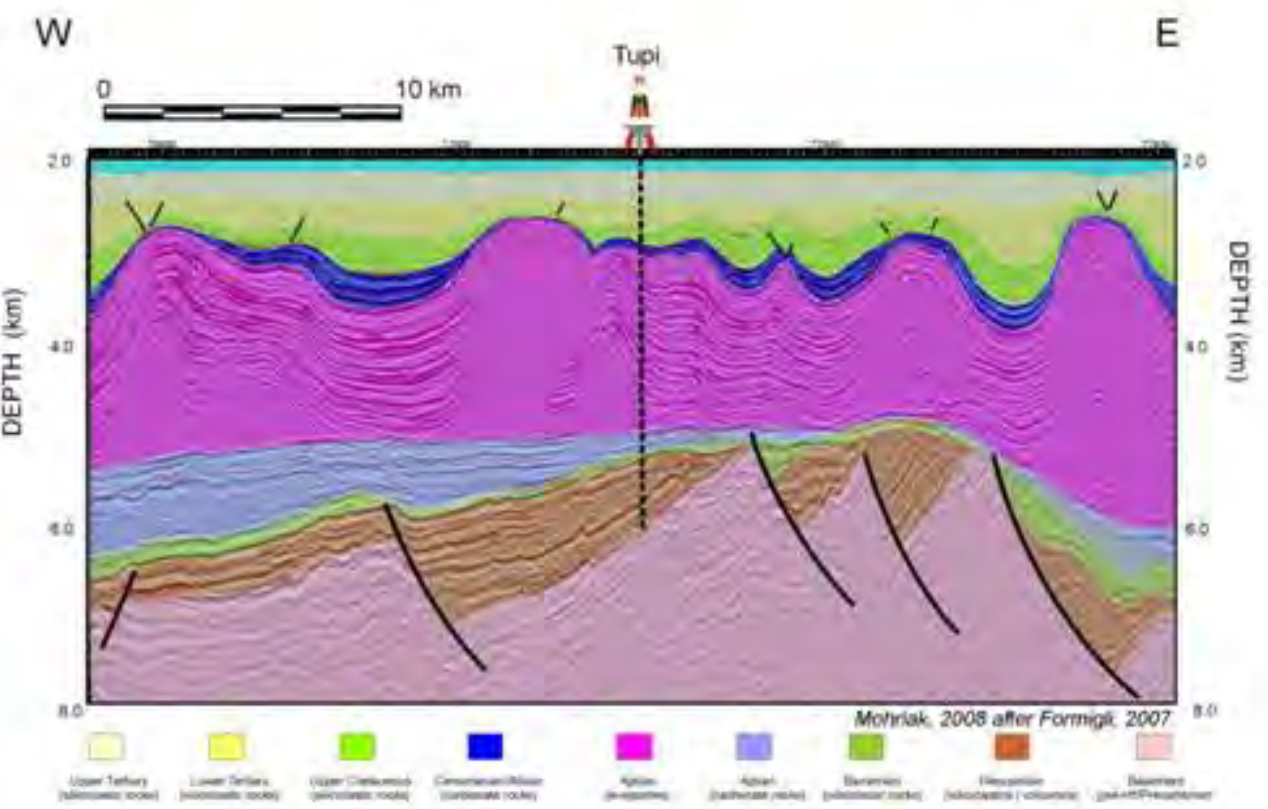




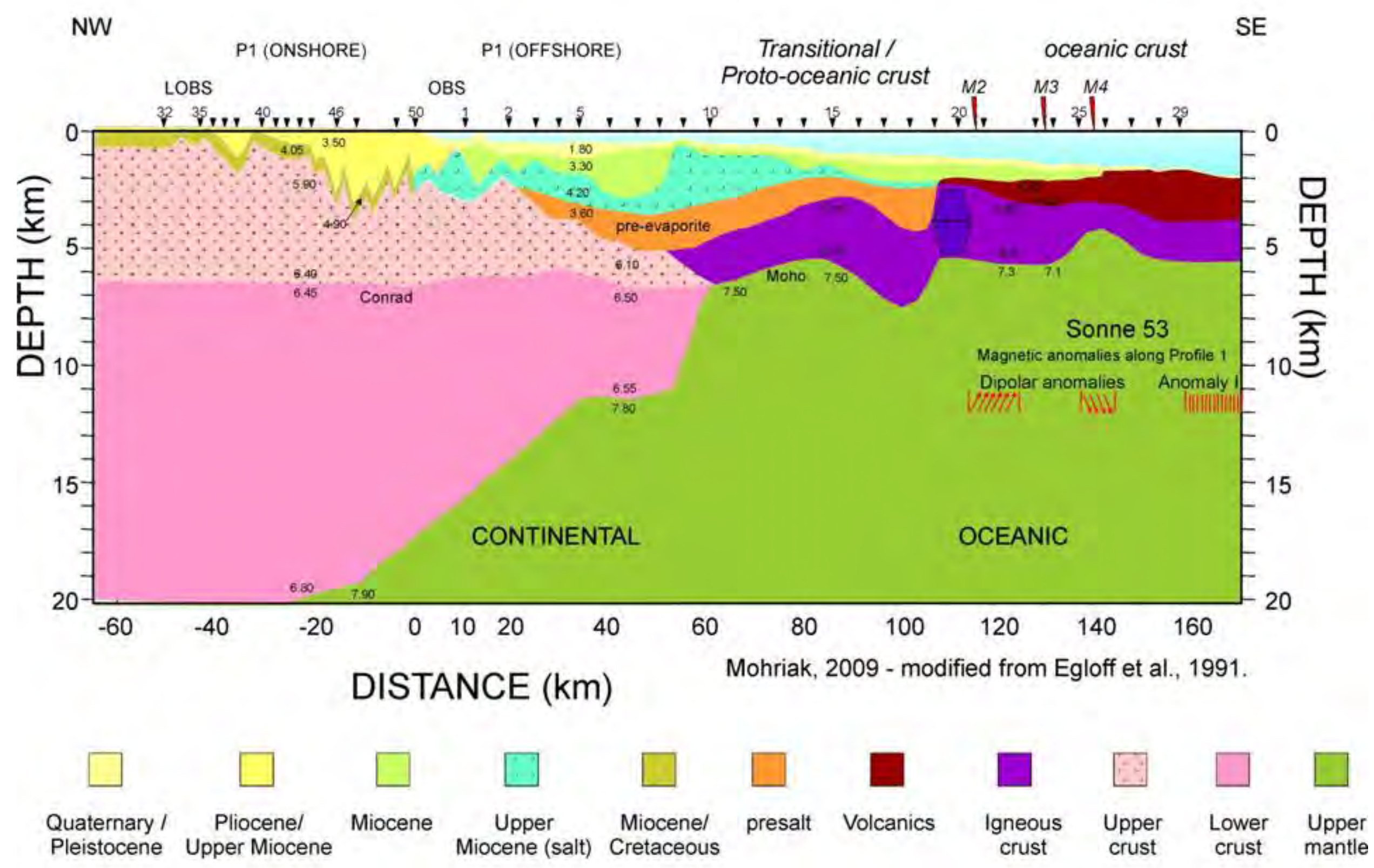



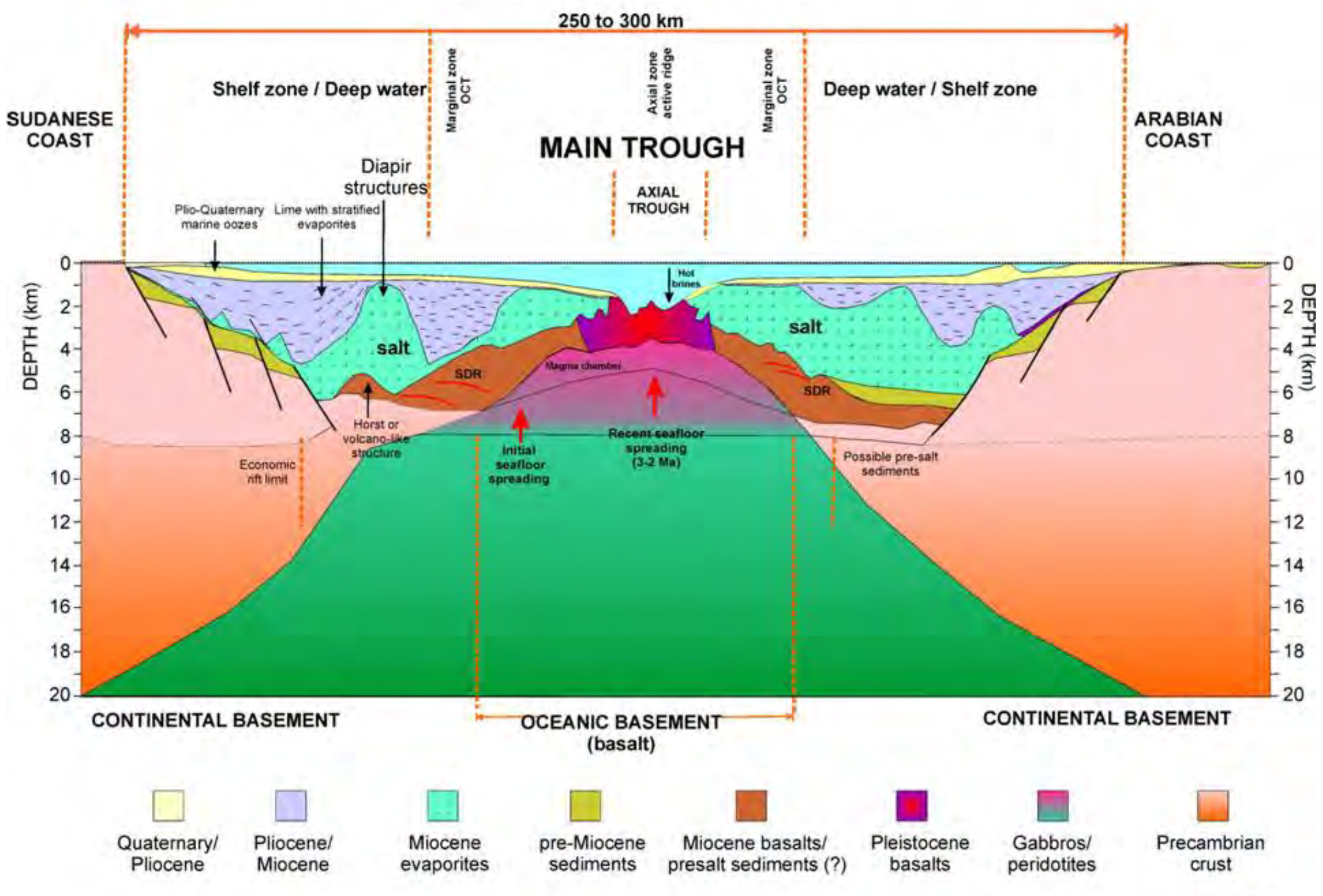
Comparison of seismic profiles in the present-day spreading ridge in the central Red Sea (see location on Figure 5) with an embryonic spreading center in the southern Santos Basin, interpreted as an oceanic propagator aborted before the final breakup. (A) In the Red Sea, the top of the evaporites is characterized by an undulating topography indicative of early halokinesis, resulting in anticlinal and synclinal structures and mini-basins. (B) The Abimael Ridge propagated from the Pelotas towards the Santos Basin in the Early Cretaceous and was aborted in the early Albian, but separated salt basins by incipient spreading in the axial trough, which has been preserved in the Brazilian side of the conjugate margins.

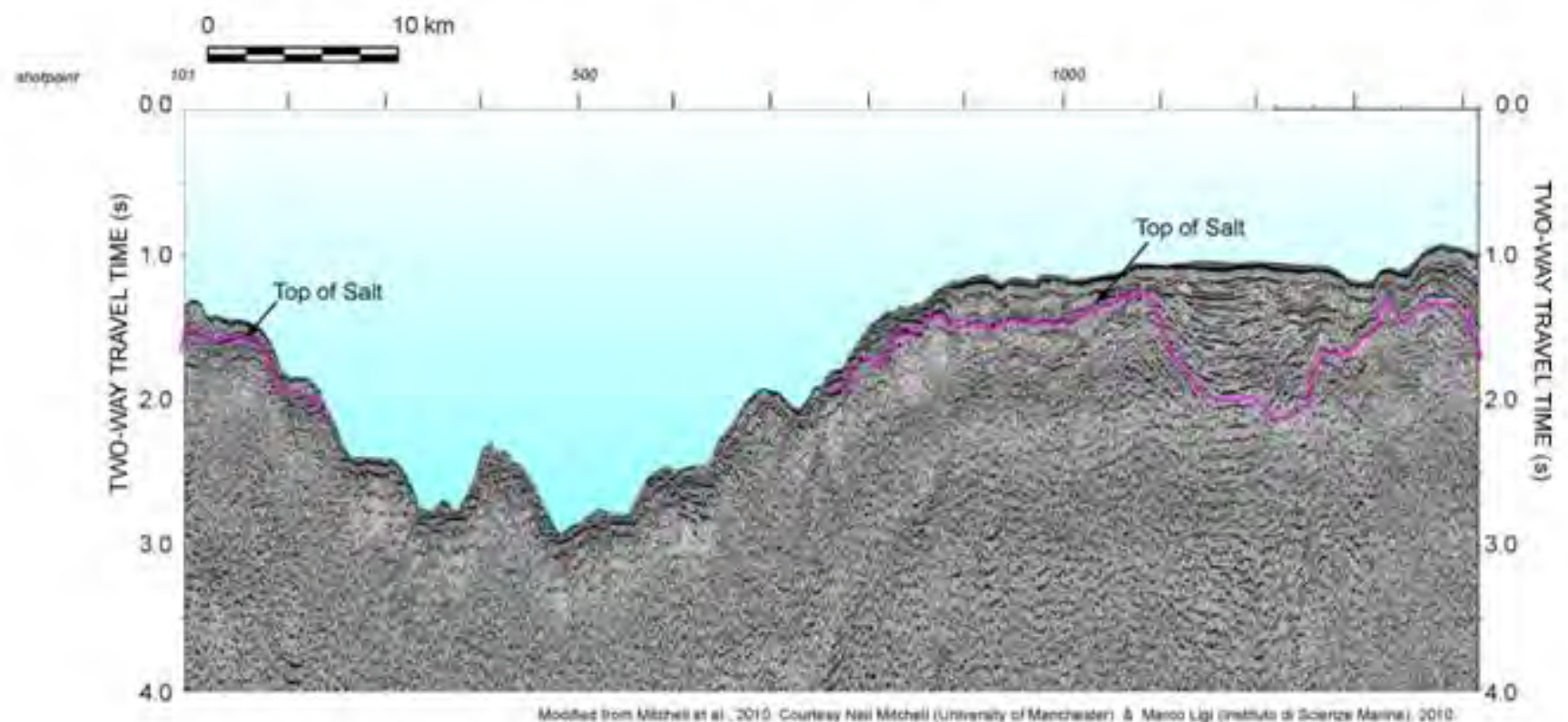

NW

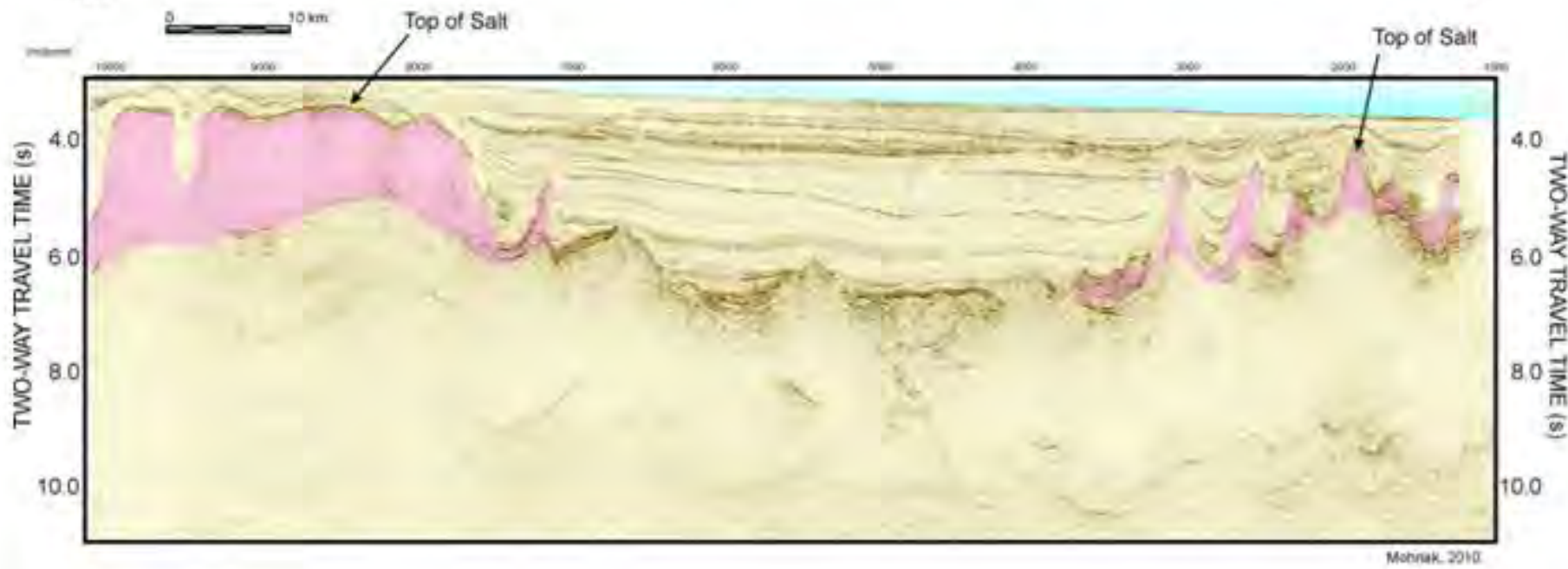




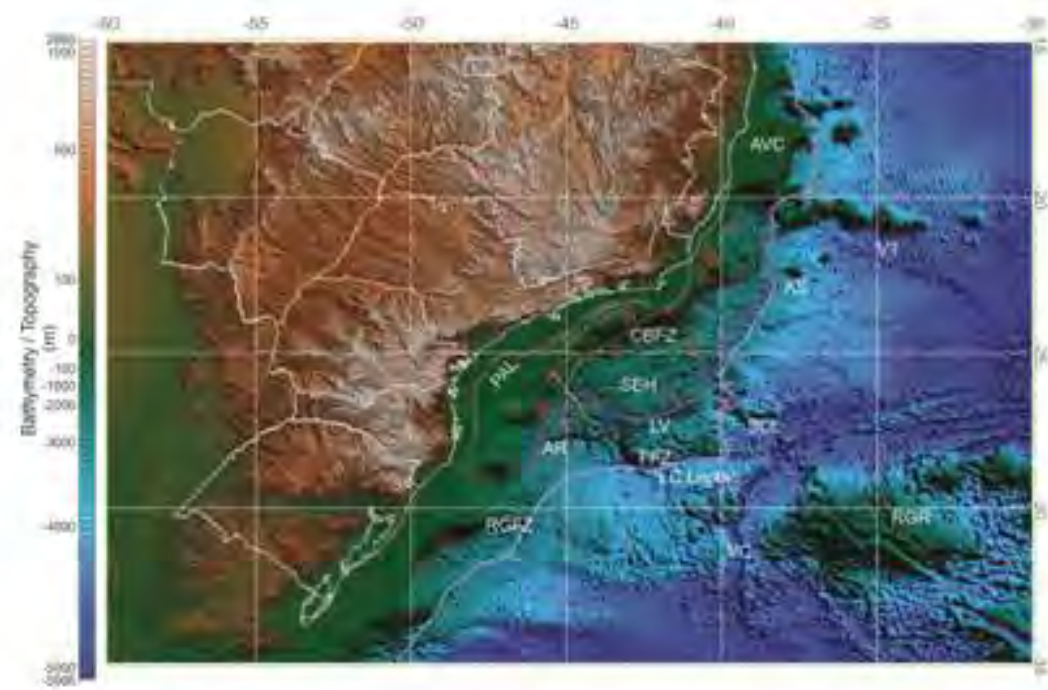

NW

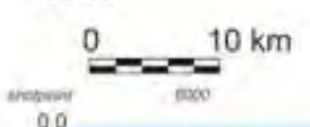

w

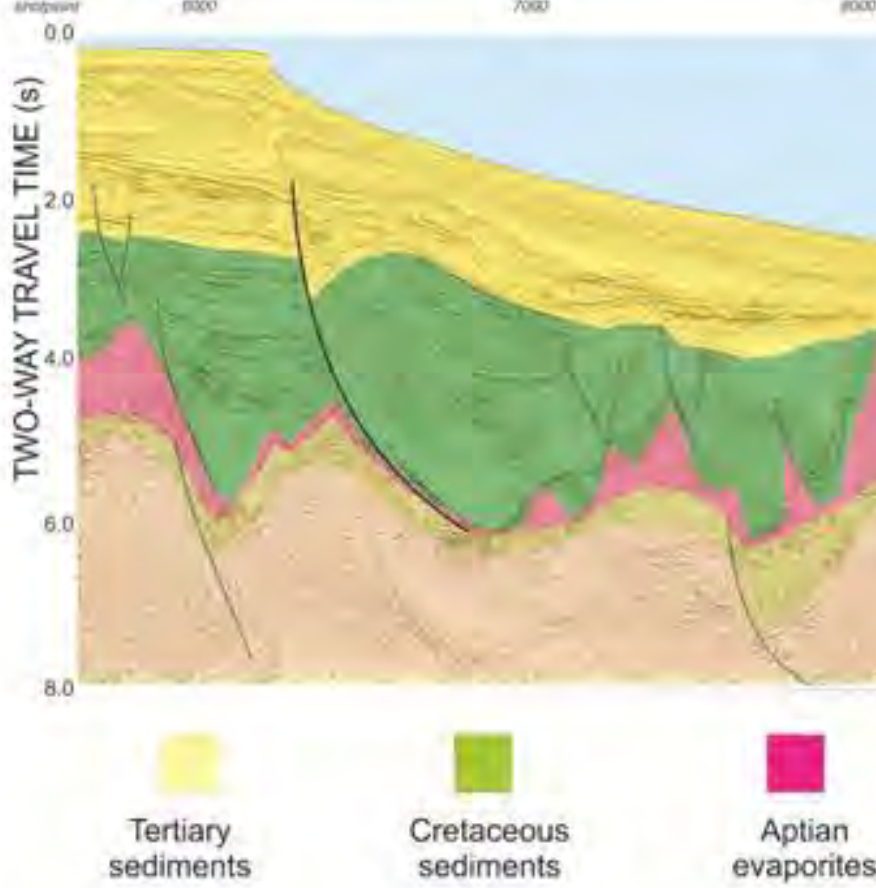

(A) Topo-bathymetric map of the Southeastern Brazilian region with location of earthquake epicenters and main tectonic elements along the continental margin. Location of the seismic profile is indicated by the yellow line.

AR: Abimael Ridge; AS: Almirante Saldanha Seamount; AVC: Abrolhos Volcanic

Complex; CBFZ: Cabo Frio Fault Zone; FFZ: Florianópolis Fracture Zone; LC Leplac: Limit of crusts from Leplac project; LV: Limit of volcanic basement; PAL: pre-Aptian limit of the continental margin basins: RGFZ: Rio Grande Fracture Zone; RGR: Rio Grande Rise;

SCL: Southern Cross (Cruzeiro do Sul) Lineament; SEH: Southeast Santos Basin High; VT: Vitória-Trindade Lineament;

(B) Separation of the Late Aptian salt basins by an Incipientvolcanic spreading center in the southern Santos Basin. Alternative interpretations suggest a peridotite ridge or belt of exhumed mantle; however, the feature is characterized by a negative magnetic anomaly and by a positive gravity anomaly.

Incipient volcanic spreading center / peridotite ridge / exhumed mantle (?)

\section{SE}

now noso

nowo 0.0

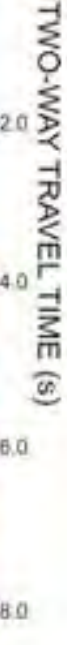

Early Cretaceous sediments
Volcanic / Precambrian basement
Igneous accretion / peridotite (?) 

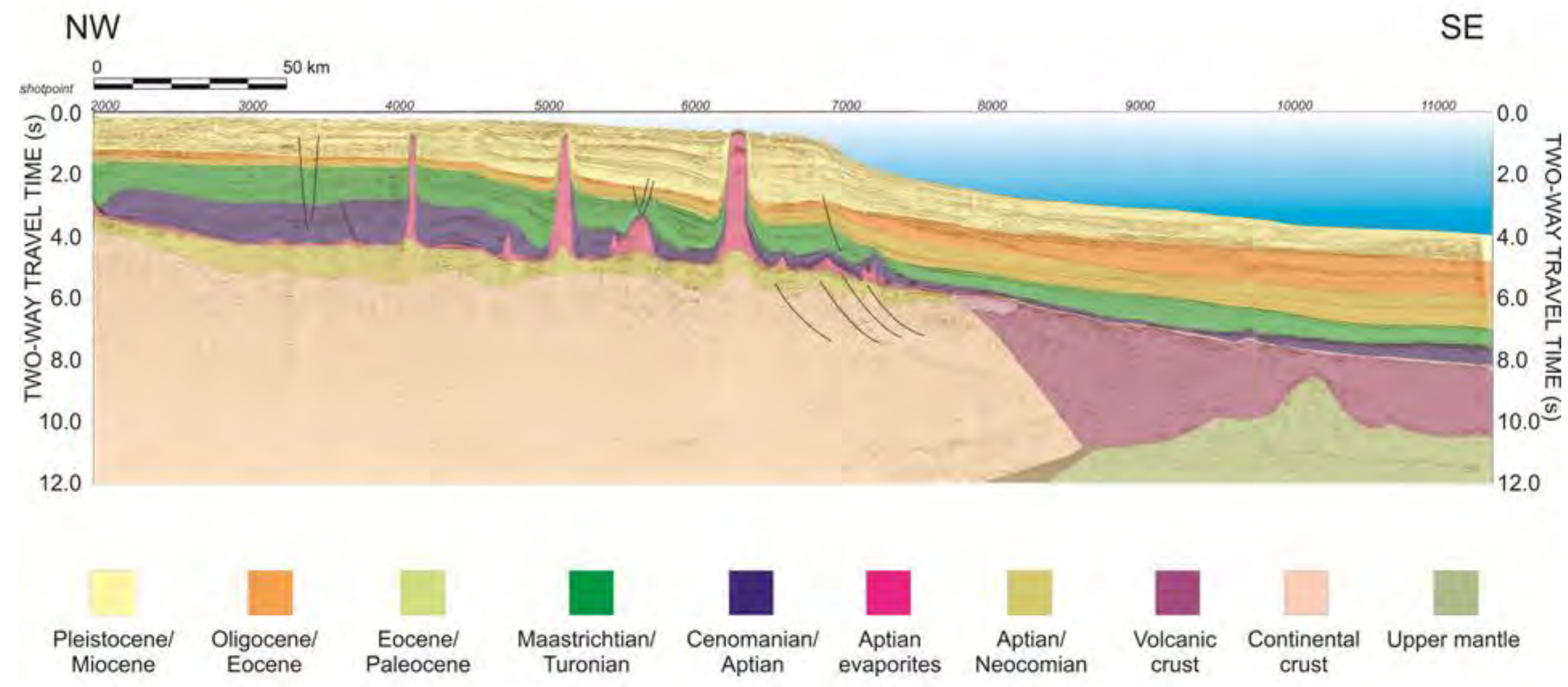
Simplified geological map of the Gulf of Aden - Red Sea region, with main structural elements. Seismic profiles indicate the occurrence of volcanoes near the continent-ocean transition in the Gulf of Aden. The Aden ridge separates conjugate divergent margins and is presently propagating towards the west (Gulf of Tadjura, in the Afar region).

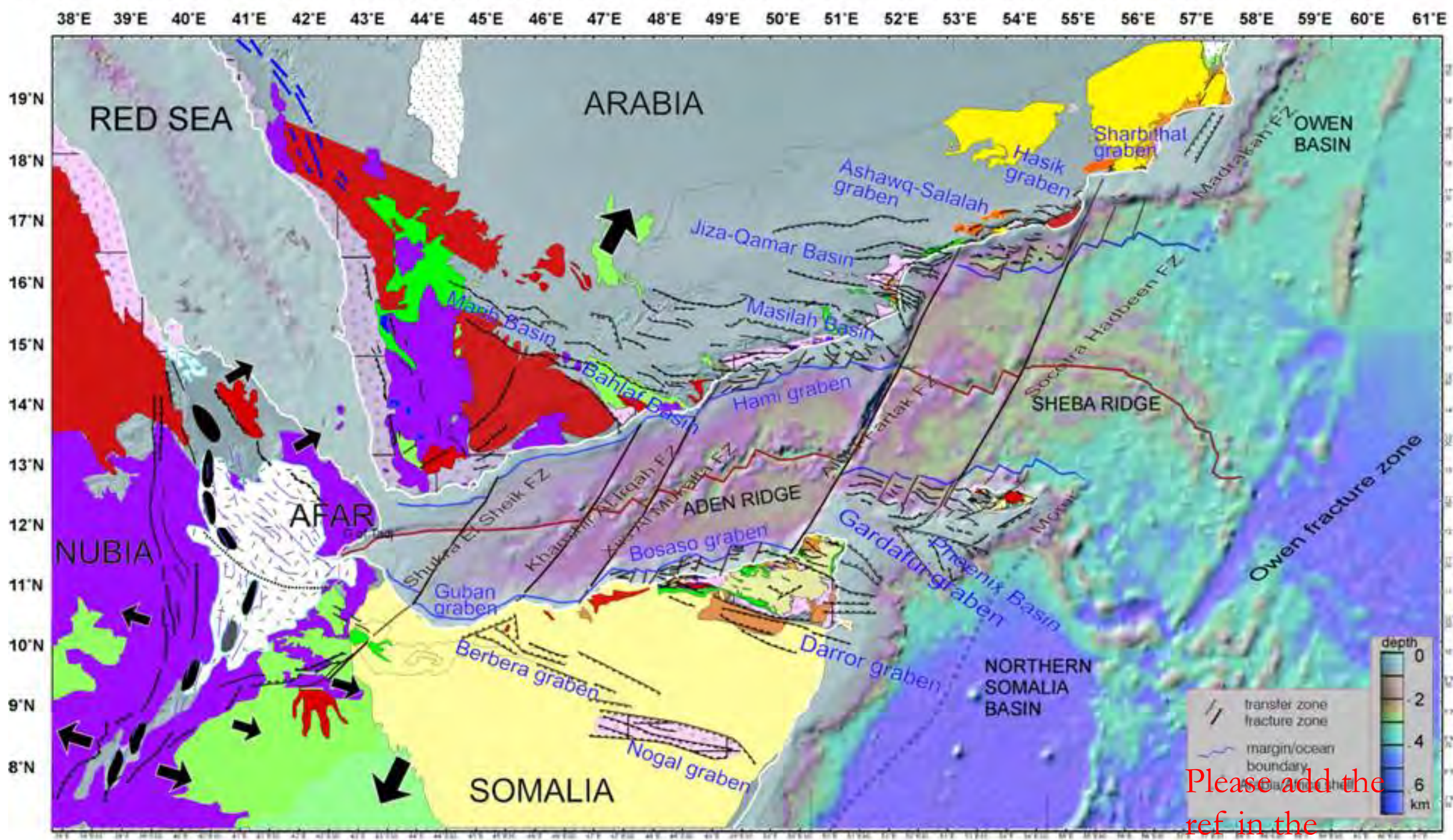

normal fault

- Quaternary fault

7 Plate Motion
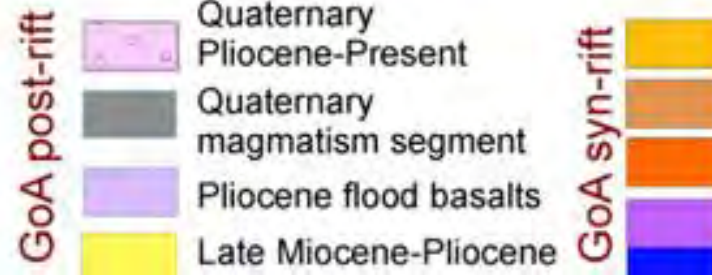

Oligo-Miocene (marine)

Oligo-Miocene

(Continental)

Priabonian

Cenozoic volcanism

Tertiarv Granite

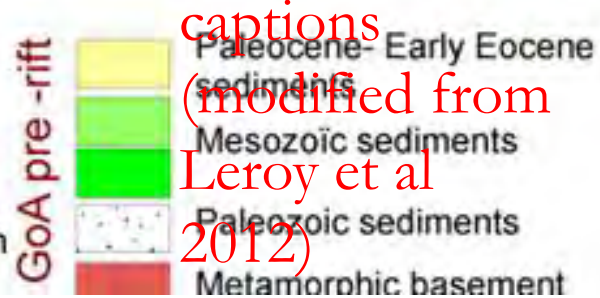


Topobathymetric map of the Gulf of Aden region with main tectonic elements and location of regional profiles in the south Oman and north Somalia conjugate margins. The ShebaRidge is offset by major transform faultzones and is marked by increased magmatic activity in Pleistocene to Recent times, particularly along the segment between the Socotra Fracture Zone and the Alula-Fartak Fracture Zone. The Aden Ridge is propagating towards the Afar region, and the conjugate margins west of the Shukra El Sheik

Fracture Zone are clearly volcanic. Regional seismic transects near the Socotra-Hadbeen transform faultzones are characterized by Neogene rift basins in the proximal part.

0

$500 \mathrm{~km}$
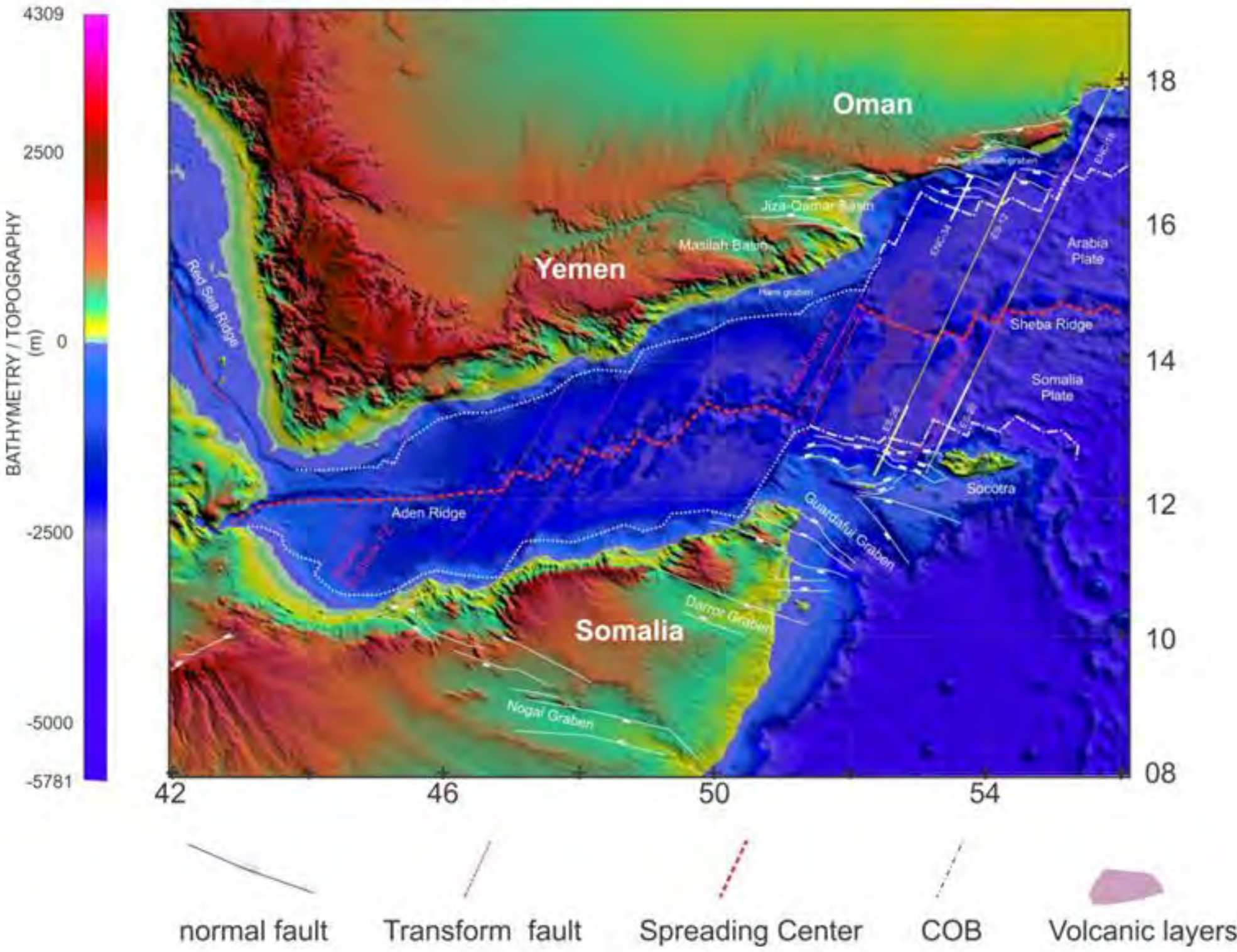
Topobathymetric map of the Afar region where Neogene volcanic rocks are associated with a mantle plume and extensional tectonics forming depressions adjacent to the Red Sea and Gulf of Aden. The Erta Ale volcano is characterized by bluish colors and is located west of the Danakil horst, northwest of the Gulf of Tadjura, the western tip of the Aden propagator. The Asal Lake (light blue color) is located immediately to the west of the Gulf of Tadjura. Several volcanoes and lava flow deposits occur onshore, west of the Strait of Bab-el-Mandeb, a narrow link between the Red Sea and the Gulf of Aden. The conjugate margins in the Arabian and Somalian plate, nearthe Afar region, are characterized by seaward-dipping volcanic wedges.

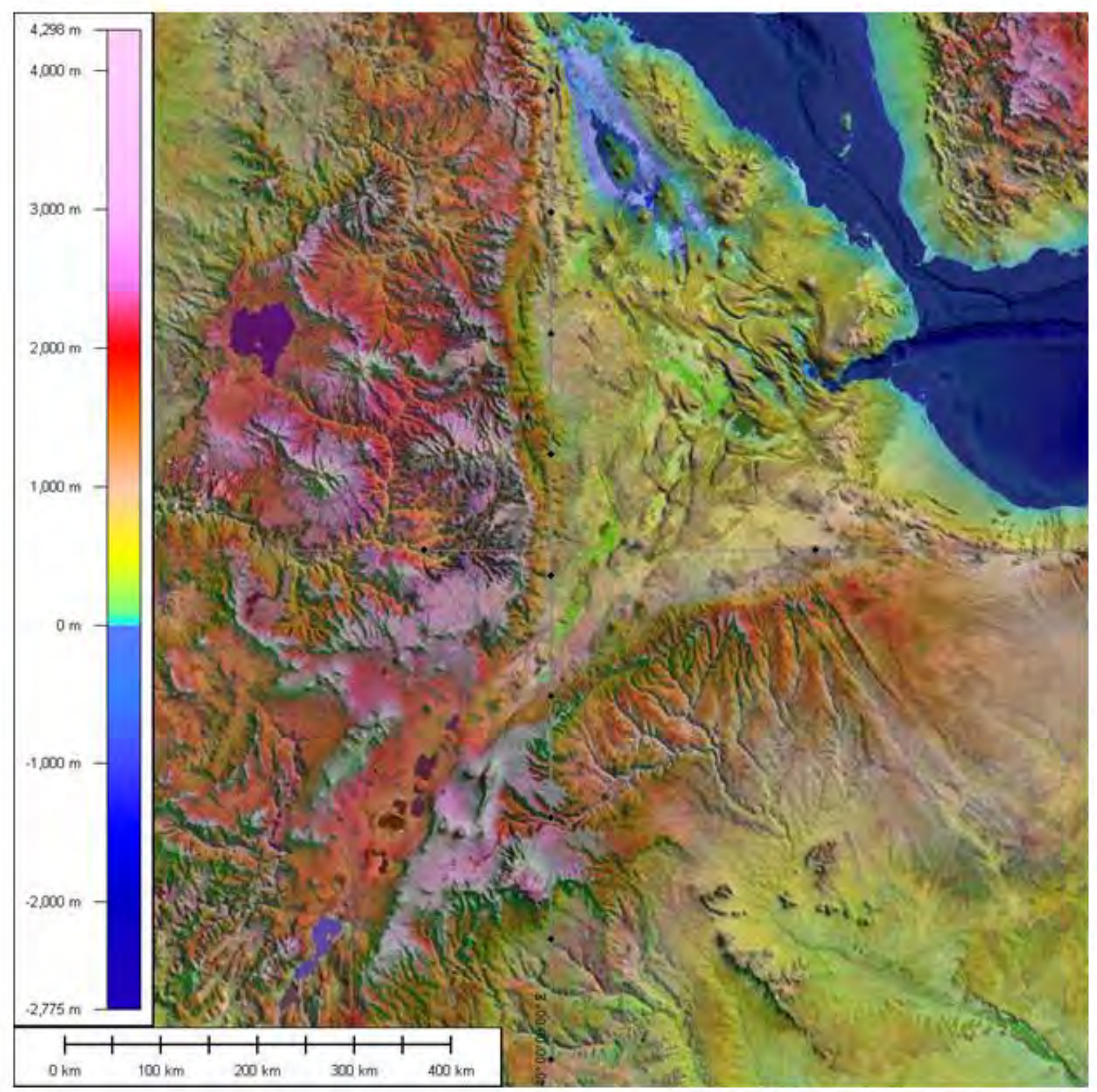



crust is characterized by magnetic anomalies indicative of organized spreading in the Miocene. Anomaly A5d (about $17.6 \mathrm{Ma}$ ) is located near the western flank of the volcano.

Younger magnetic anomalies are observed towards the present-day spreading center (Sheba Ridge), and a large volcanic province is observed near the present-day ridge crest, indicating excessive magmatismat the plate boundary.

Oceanic crust

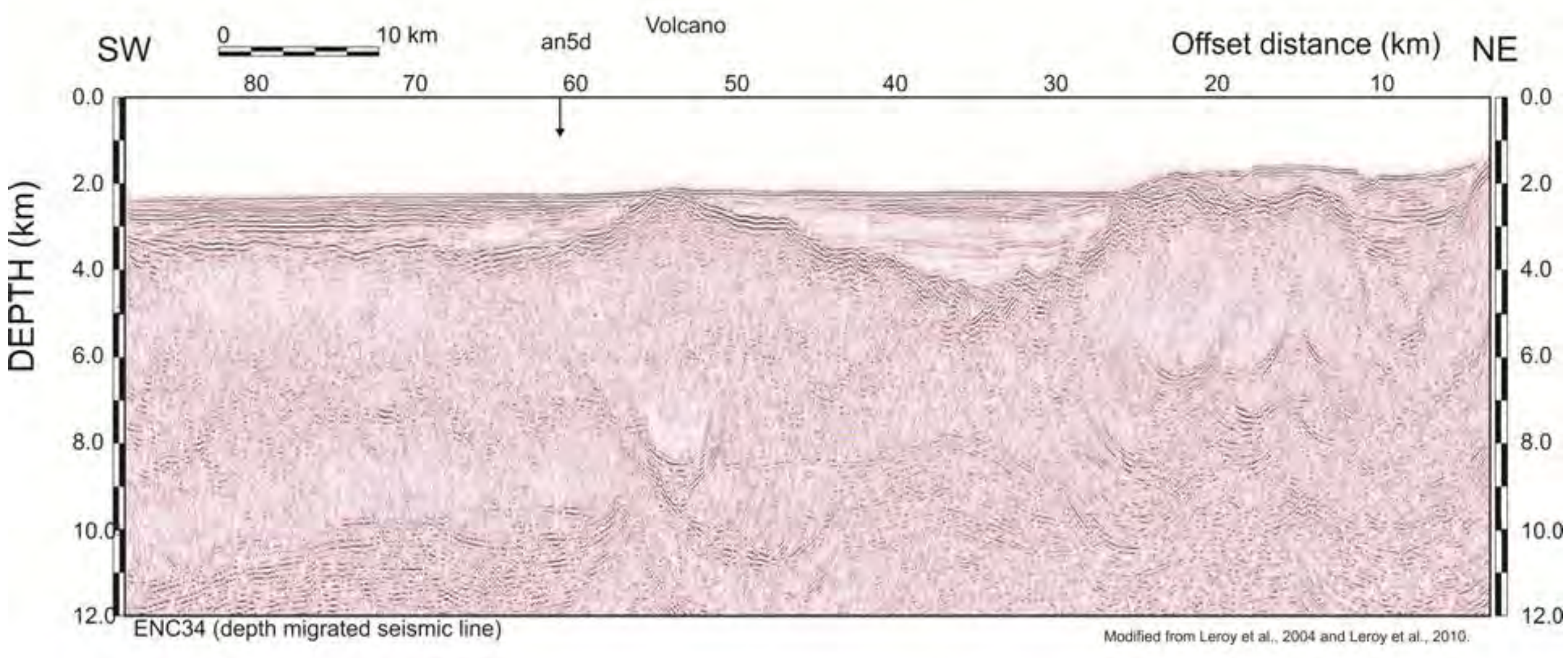

Continental Crust

Ocean-Continent Transition

Modified from

Autin et al 2010

\& Leroy et al

$2.010 \mathrm{~h}$ 
Schematicline interpretation of the seismic profile ENC-34 in the northern Gulf of Aden, crossing the Ashawk-Salalah graben and extending through the ocean-continent transition (which is marked by rotated blocks and a sag basin). A volcanic build-up overlies the OCT volcanics and sediments in the transition from continental to oceanic crust. A magmatically accreted igneous crust (with possible underplating) is interpreted near the continent-ocean transition, but there is an alternative possibility of mantle exhumation near the continent-ocean boundary. The oceanic crust is characterized by magnetic anomalies indicative of organized spreading in the Miocene (anomalies A6 to A5, 20 to $16 \mathrm{Ma}$ ). Increased magmatismis indicated towards the present-day Sheba Ridge, which separates the Somalian and the Arabian plates.

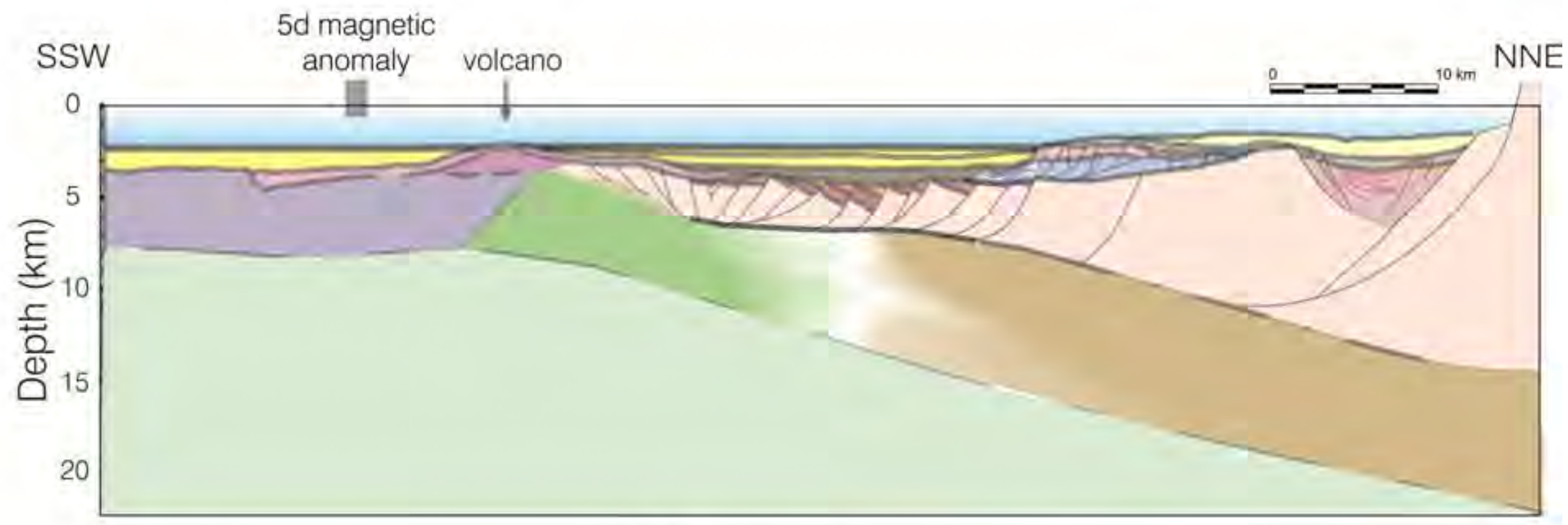

\section{Sequences}

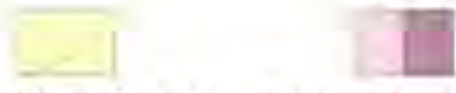

Post rift U3-4-5 Volcanic features
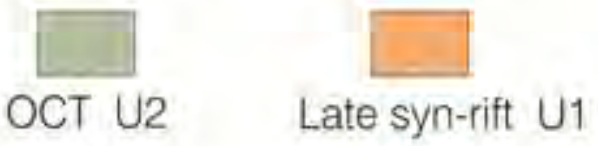

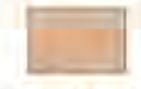

syn-rift U1
Pre-rift (and basement)

\section{Lithosphere}
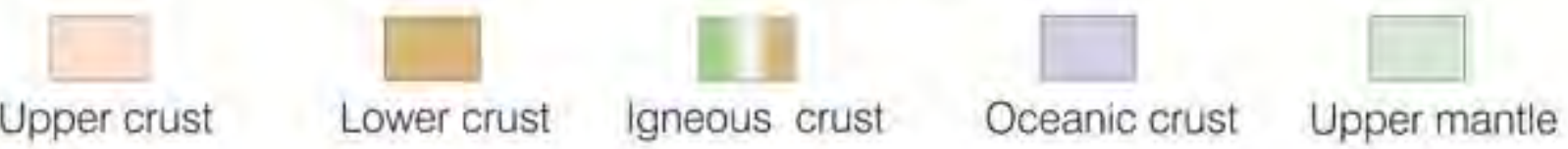
(A) Schematic reconstruction of the Socotra-Oman pre-breakup rifted basins in the Gulf of Aden, corresponding to the transect east of the Socotra Fracture Zone on Figure 16. It shows the complementary asymmetry of the opposing margins and the distribution of the Neogene rifts. The location of the breakup where the oceanic spreading center initially formed is offset towards Socotra, resulting in a narrow margin. A detachment is interpreted to occur at shallower depths in the lower plate (Socotra) and penetrate deeper into the crust towards the upper plate, which is characterized by the Southern Oman margin rift basins.

(B) After breakup, organized spreading formed an oceanic crust characterized by magnetic anomalies that date back to anomaly $5 \mathrm{~d}$ (about $17.6 \mathrm{Ma}$ ). The Sheba Ridge is the present-day spreading center, marked by a bathymetric low and large magnetic anomalies.

\section{(A) Pre-breakup}

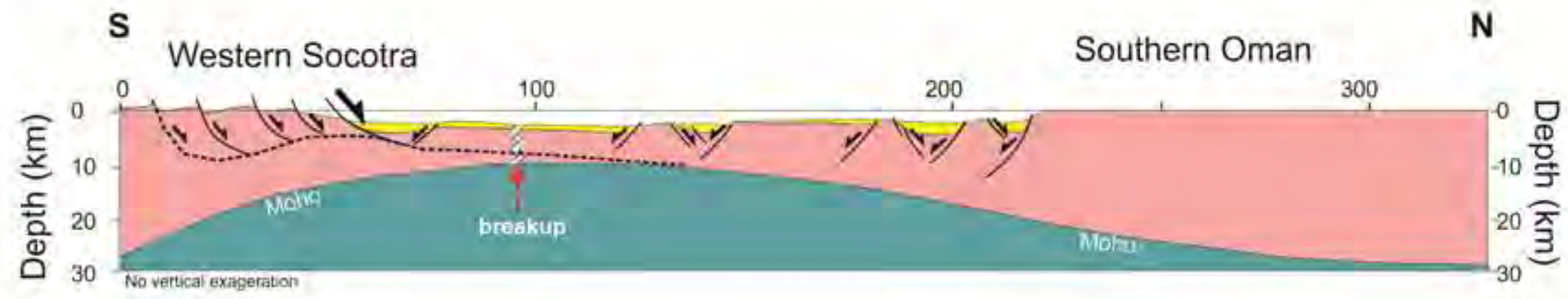

\section{(B) Present day}

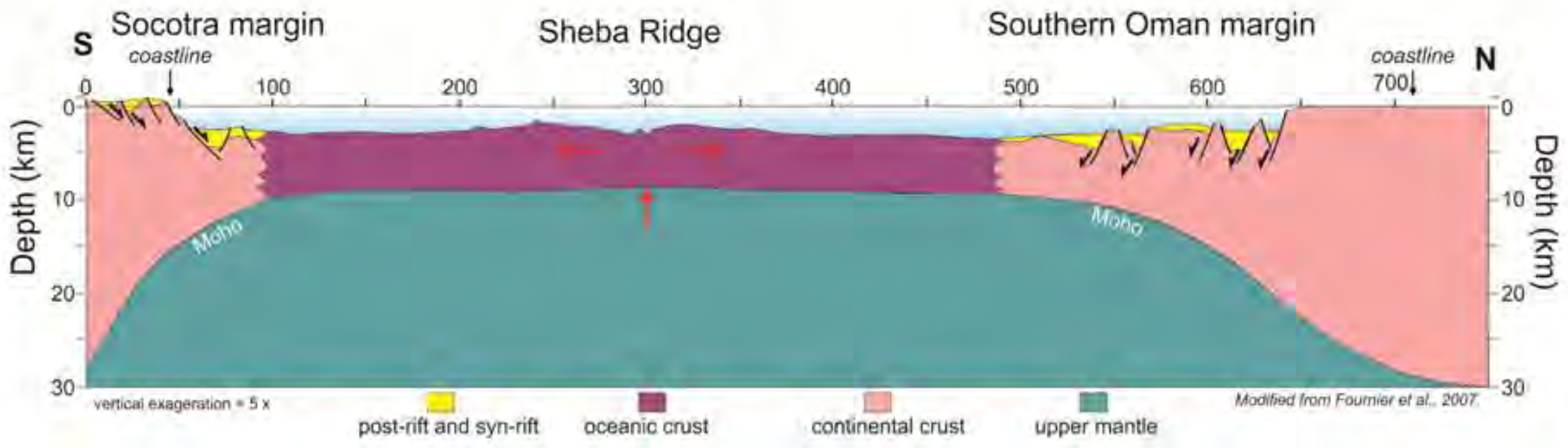


Reconstruction map of the Gulf of Aden and the Neogene rifts between the Arabian and Somalian plates just before the continental breakup and formation of oceanic crust (about $18 \mathrm{Ma}$ ). Large grabens onshore Yemen and Somalia (example, Balhaf and Berbera, Masilah and Darror) were formed during pre-Cretaceous extensional events and correspond to inherited structures with some reactivation in the Neogene.

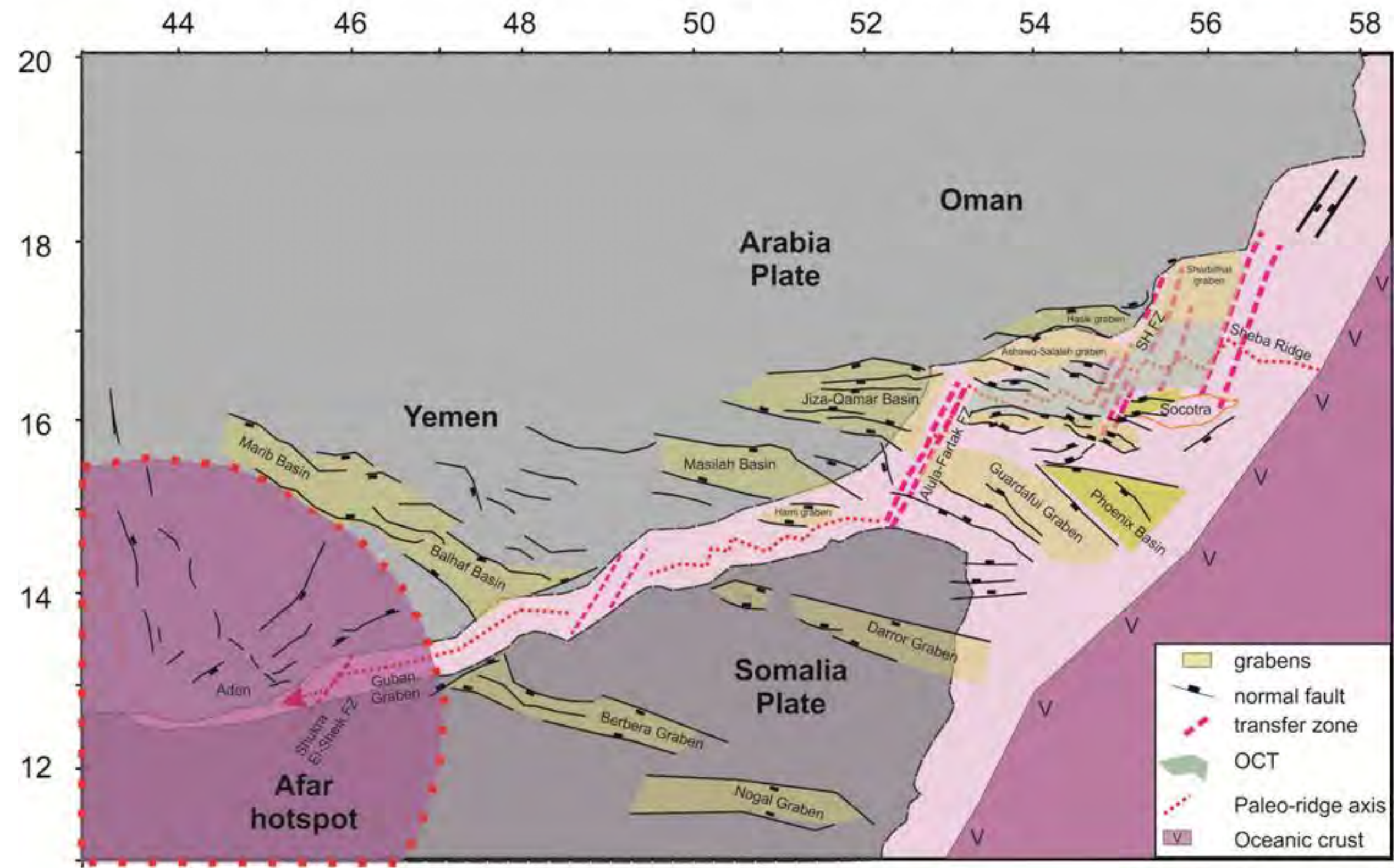

Leroy et al 20 Modified from Leroy et al., 2011. 
Top: reconstruction map of the South Atlantic just before continental breakup (112 Ma), with sag basins developed offshore Kwanza and in the Santos Basin; Bottom: Geoseismic transects across approximate conjugate margins offshore Brazil (B) and West Africa (A). The present-day spreading center (Mid-Atlantic Ridge) is located more than $2000 \mathrm{~km}$ beyond the continent-ocean boundary in both margins.
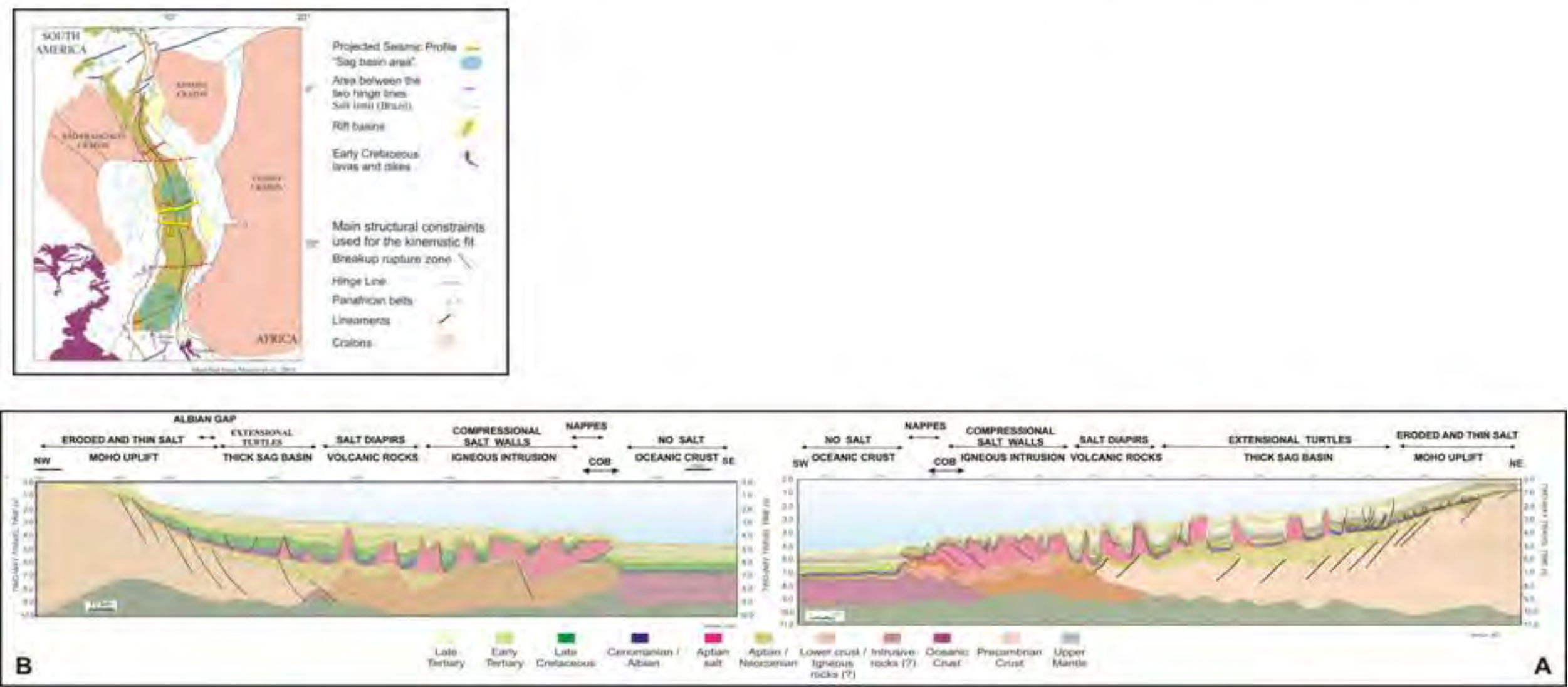
Geoseismictransect west of Socotra Fracture Zone (location on Figure 16) across the conjugate margins offshore Somalia (SSW) and South Oman (NNE). Organized spreading is indicated by magnetic anomaliesfromthe plataform (anomaly $5 \mathrm{~d}$, about $17.6 \mathrm{Ma}$ ) towards the present-day spreading center (Sheba Ridge), which is located 170 $\mathrm{km}$ from the continent-ocean boundary in the Somalian margin, and about $270 \mathrm{~km}$ from the continent-ocean boundary in the South Oman margin. Volcanicfeatures occur adjacent to the spreading center, which is a deep trough with a thin veneer of Recent sediments.

Ssw

SHEEA
PIDCE

NNE

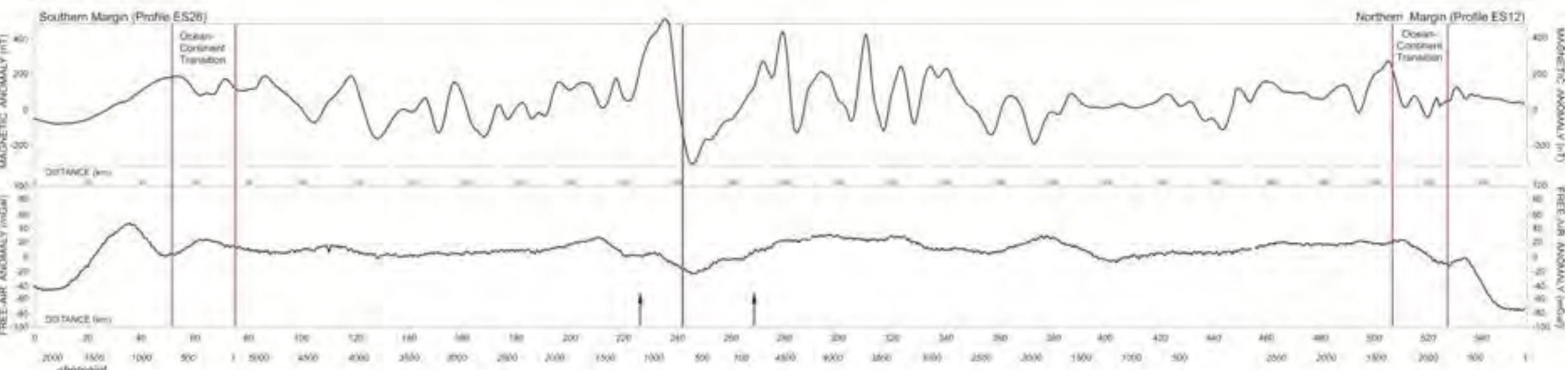

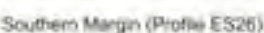

Ese
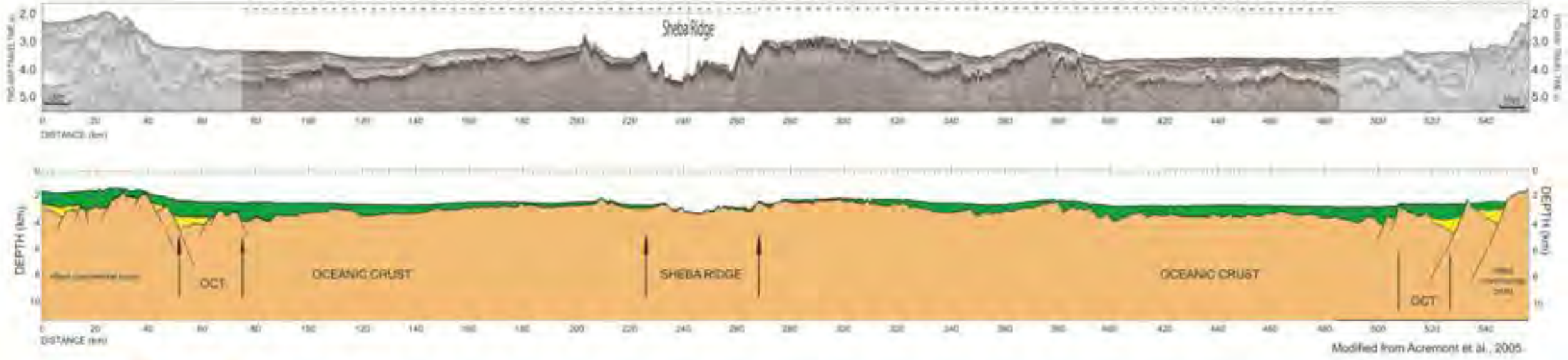

post-rift syn-rift basement

Leroy et al 2004 
Continental breakup model with embryonic spreading in volcanic and non-volcanic margins. X-Y might correspond to a cross section in the Red Sea margins, still in the early stages of separation by an active spreading center. The South Atlantic correspond to a more advanced stage of margin divergence, where the oceanic crust formed about 110 $\mathrm{Ma}$ ago. Volcanicfeatures and igneous intrusions are located near the ocean-crust transition.

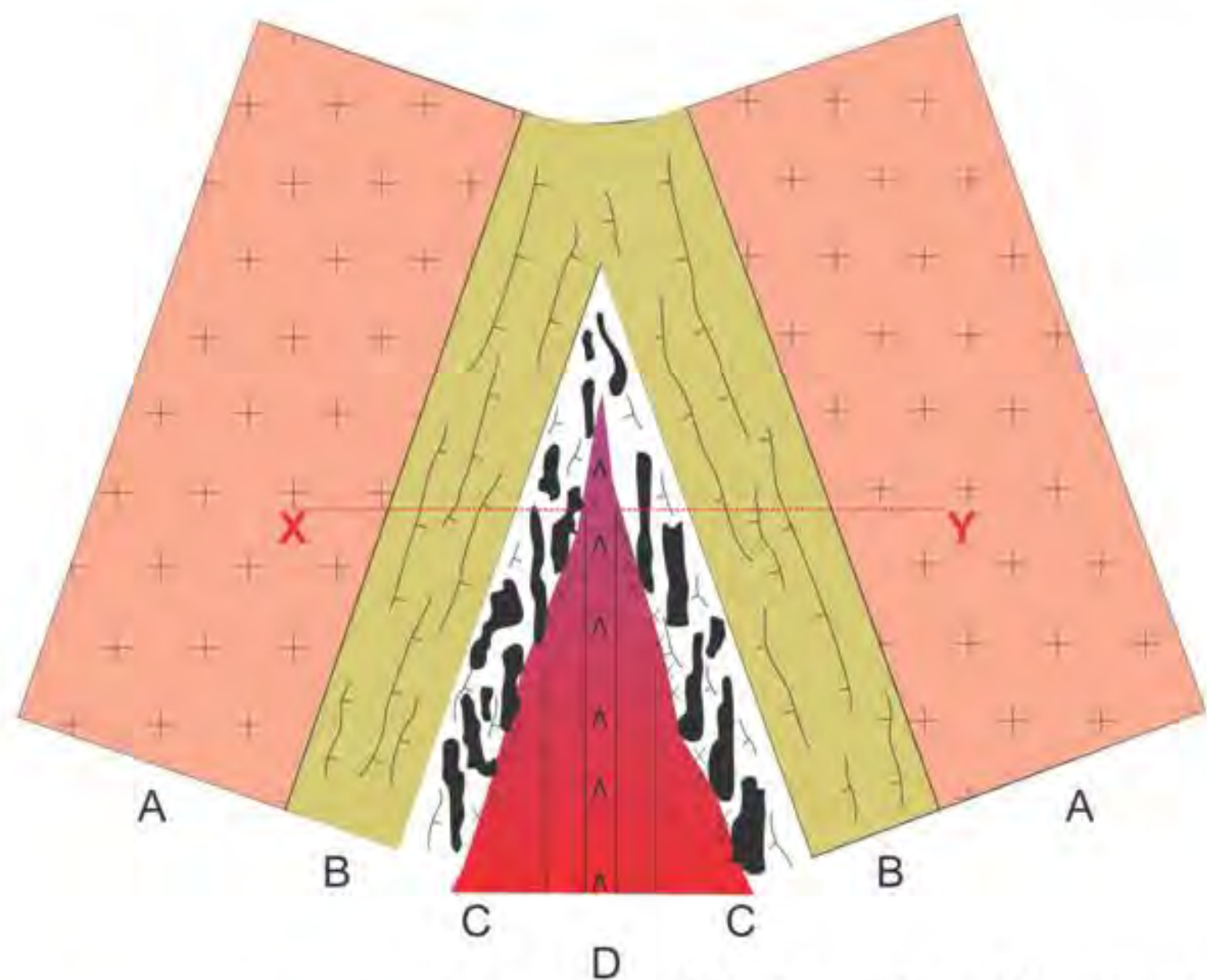

D

$\mathrm{A}+$

Unthinned crust

\section{B}

Rifted crust

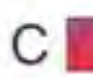

Oceanic propagator
$\mathrm{D}\left|\begin{array}{l}\wedge \\ \wedge\end{array}\right|$

Spreading Center

\section{Volcanic margins}

Transitional crust

(with igneous intrusions) (with peridotite ridges)

\section{Magma-poor margins}

Transitional crust 


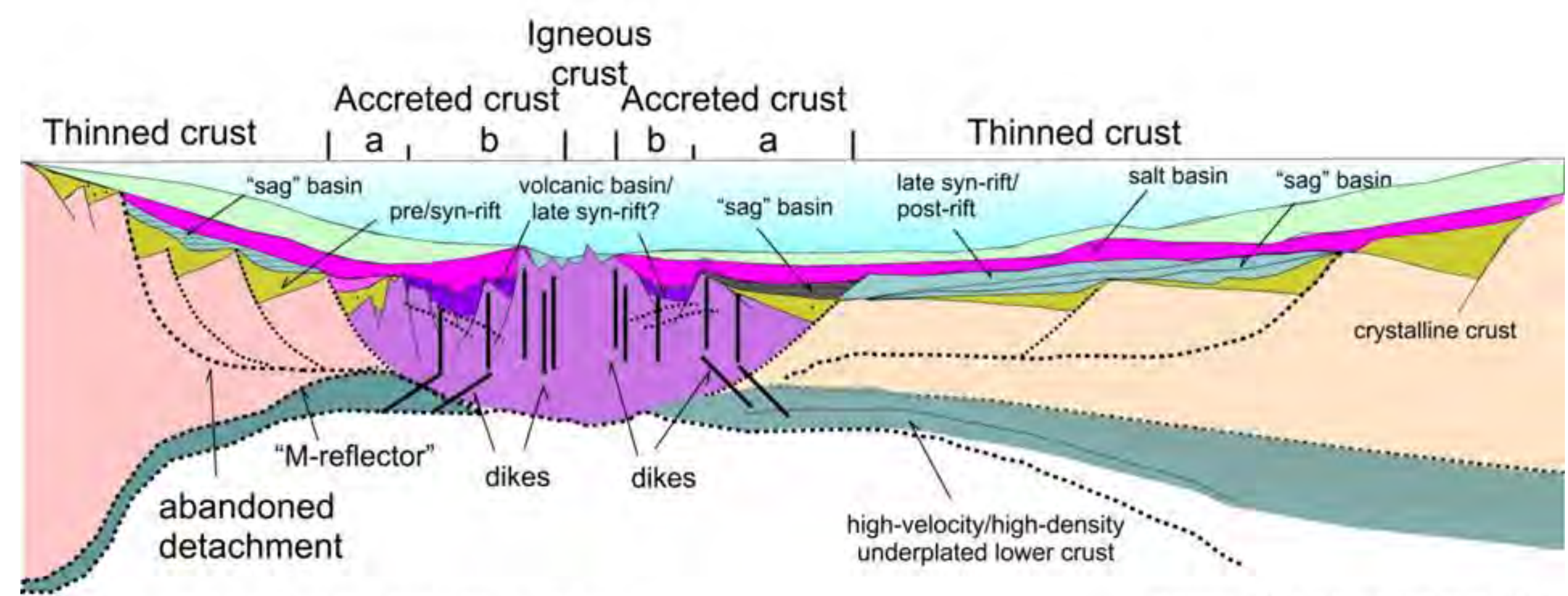

breakup and early post-breakup phase

Mohriak, 2011 after Blaich et al., 2011. 